In cooperation with the City of Houston

\title{
Water-Quality Assessment of Lake Houston Near Houston, Texas, 2000-2004
}

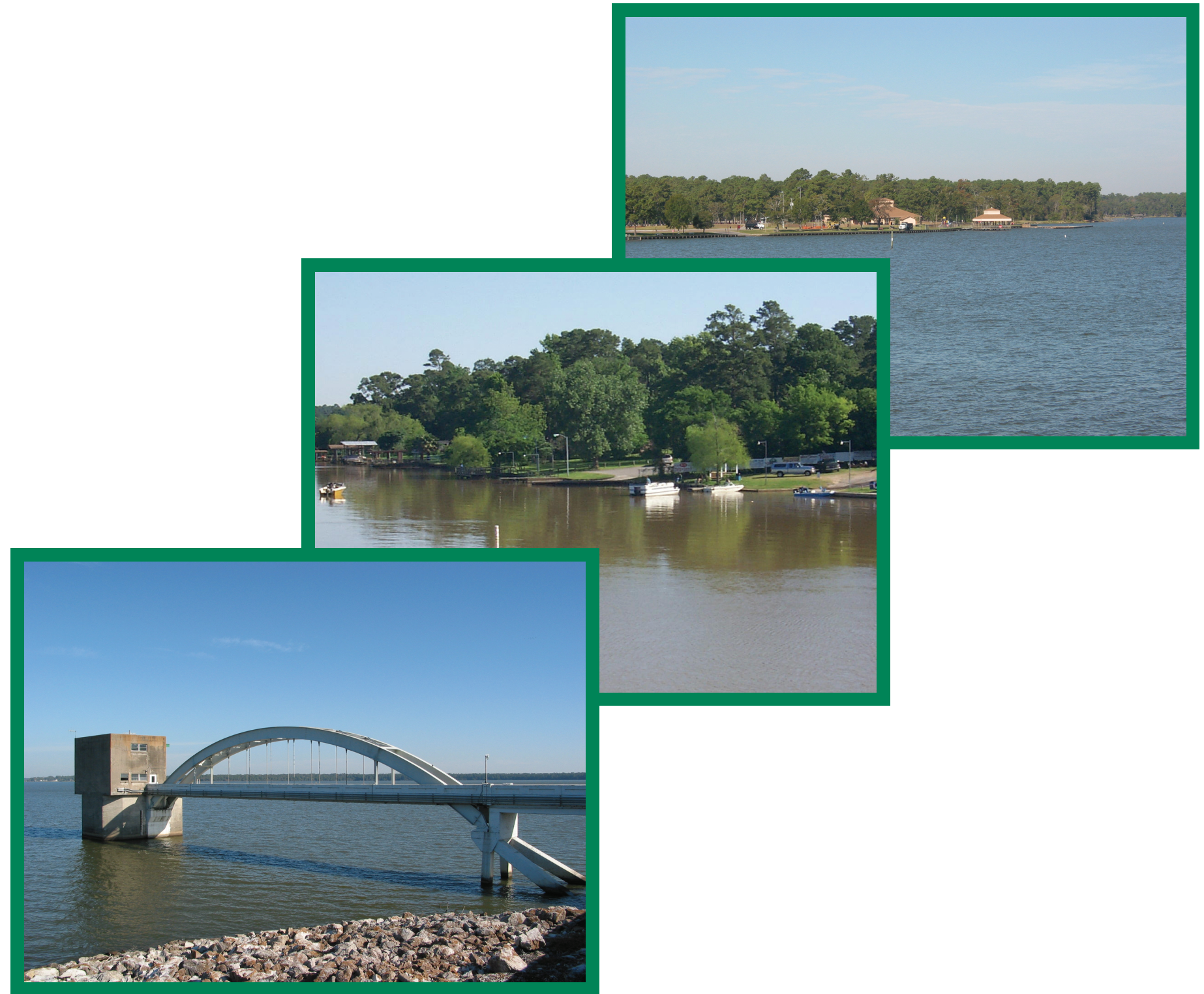

Scientific Investigations Report 
Cover. (Top) View of pavillions and waterfront of Alexander Deussen Park, looking northwest from Lake Houston spillway levee, November 8, 2005.

(Middle) View of public boat launch and marina at Lake Houston, looking north from FM 1960 bridge, April 26, 2001. (Bottom) View of the intake tower from the Lake Houston spillway levee, November 8, 2005. 


\section{Water-Quality Assessment of Lake Houston Near Houston, Texas, 2000-2004}

By Debra A. Sneck-Fahrer, Matthew S. Milburn, Jeffery W. East, and Jeannette H. Oden

In cooperation with the City of Houston

Scientific Investigations Report 2005-5241 


\section{U.S. Department of the Interior Gale A. Norton, Secretary}

\section{U.S. Geological Survey \\ P. Patrick Leahy, Acting Director}

\section{U.S. Geological Survey, Reston, Virginia: 2005}

For sale by U.S. Geological Survey, Information Services

Box 25286, Denver Federal Center

Denver, CO 80225

For more information about the USGS and its products:

Telephone: 1-888-ASK-USGS

World Wide Web: http://www.usgs.gov/

Any use of trade, product, or firm names in this publication is for descriptive purposes only and does not imply endorsement by the U.S. Government.

Although this report is in the public domain, permission must be secured from the individual copyright owners to reproduce any copyrighted materials contained within this report.

Suggested citation:

Sneck-Fahrer, D.A., Milburn, M.S., East, J.W., and Oden, J.H., 2005, Water-quality assessment of Lake Houston near Houston, Texas, 2000-2004: U.S. Geological Survey Scientific Investigations Report 2005-5241, 55 p. 


\section{Contents}

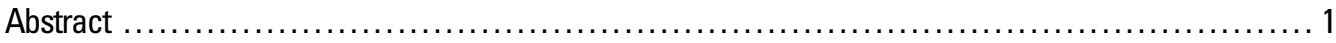

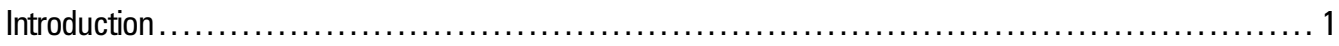

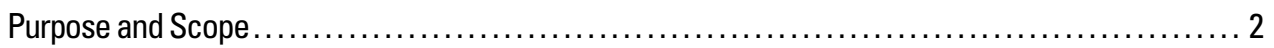

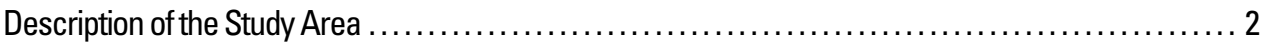

Sources and Implications of Nitrogen, Phosphorus, Suspended Sediment, Organic Carbon, Turbidity, Chlorophyll-a, and Pesticides ..................................... 4

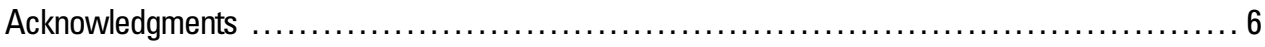

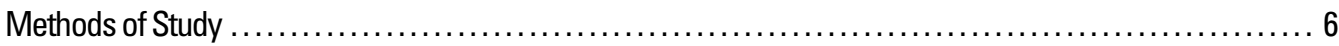

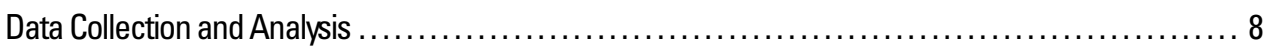

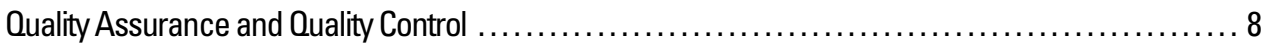

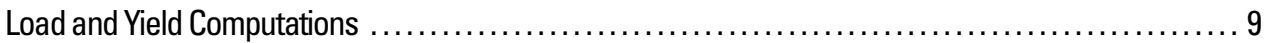

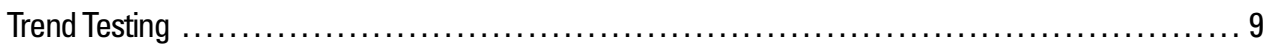

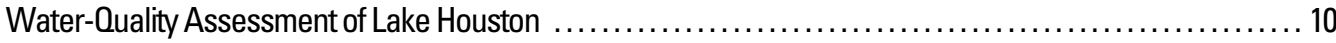

Ambient Conditions, 2000-2004 ................................................ 10

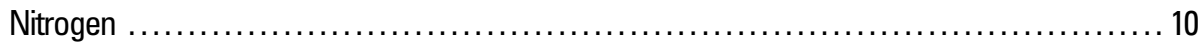

Phosphorus, Suspended Sediment, and Organic Carbon .......................... 10

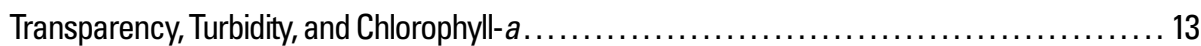

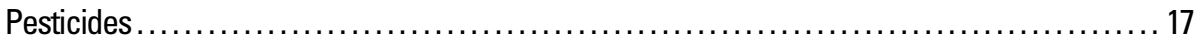

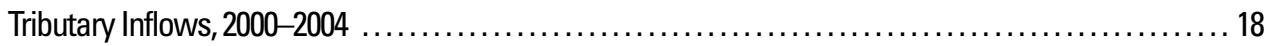

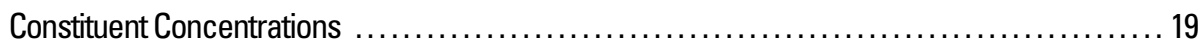

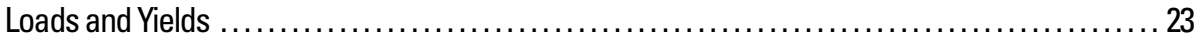

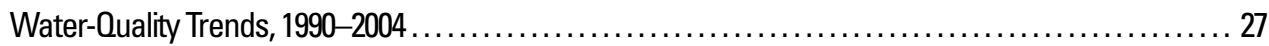

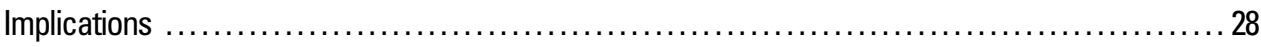

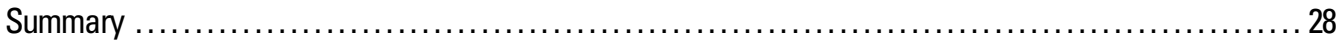

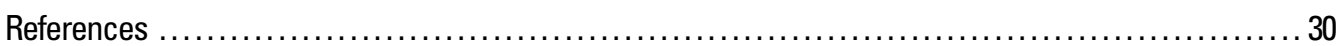

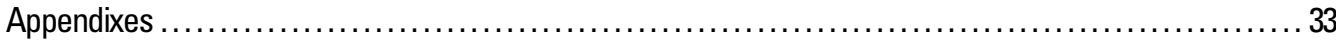

1. Statistical Summary of Field Measurements and Physical Properties, Major Cations and Anions, Nutrients, Biological Constituents, Trace Elements, and Pesticides at Lake

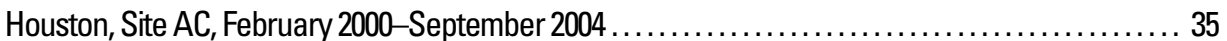

2. Statistical Summary of Field Measurements and Physical Properties, Major Cations and Anions, Nutrients, Biological Constituents, Trace Elements, and Pesticides at Lake Houston, Site EC, February 2000-September 2004

3. Statistical Summary of Field Measurements and Physical Properties, Major Cations and Anions, Nutrients, Biological Constituents, Trace Elements, and Pesticides at Lake Houston,

Site FC, February 2000-September 2004

4. Statistical Summary of Field Measurements and Physical Properties, Major Cations and Anions, Nutrients, Biological Constituents, Trace Elements, and Pesticides in Samples Collected From Low Flows at Cypress Creek, June 2000-September 2004

5. Statistical Summary of Field Measurements and Physical Properties, Major Cations and Anions, Nutrients, Biological Constituents, Trace Elements, and Pesticides in Samples Collected From High Flows at Cypress Creek, April 2002-November 2004 . 
6. Statistical Summary of Field Measurements and Physical Properties, Major Cations and Anions, Nutrients, Biological Constituents, Trace Elements, and Pesticides in Samples Collected From Low Flows at East Fork San Jacinto River, June 2000-September 2004

7. Statistical Summary of Field Measurements and Physical Properties, Major Cations and Anions, Nutrients, Biological Constituents, Trace Elements, and Pesticides in Samples Collected From High Flows at East Fork San Jacinto River, April 2002-November 2004

\section{Figures}

1-3. Maps showing:

1. Lake Houston drainage basin (study area) near Houston, Texas ..................... 3

2. Land-cover distribution in the Lake Houston drainage basin near Houston, Texas, 2002 ..... 5

3. Data-collection sites at Lake Houston, Cypress Creek, and East Fork San Jacinto River near Houston, Texas, 2000-2004

4. Graphs showing (a) total nitrogen and (b) relative contributions to total nitrogen of nitrite plus nitrate nitrogen and ammonia plus organic nitrogen at three sites in Lake Houston near Houston, Texas, February 2000-September 2004

5. Boxplots showing distribution of (a) total nitrogen, (b) nitrite plus nitrate nitrogen, and (c) ammonia plus organic nitrogen at three sites in Lake Houston near Houston, Texas, February 2000-September 2004

6 Graph showing median concentrations of orthophosphate phosphorus, dissolved phosphorus, and total phosphorus at three sites in Lake Houston near Houston, Texas, February 2000-September 2004

7-9. Boxplots showing distribution of:

7. (a) Dissolved phosphorus, (b) suspended sediment, and (c) dissolved organic carbon at three sites in Lake Houston near Houston, Texas, February 2000-September 2004

8. (a) Transparency, (b) turbidity, and (c) chlorophyll-a at three sites in Lake Houston near Houston, Texas, February 2000-September 2004 ....

9. (a) Atrazine, (b) 2-chloro-4-isopropylamino-6-amino-s-triazine (CIAT), (c) diazinon, and (d) simazine at three sites in Lake Houston near Houston, Texas, February 2000September 2004

10. Hydrographs showing discharge, 2000-2004, and water-quality sampling during low flows (June 2000-September 2004) and high flows (April 2002-November 2004) at (a) Cypress Creek and (b) East Fork San Jacinto River near Houston, Texas

11-14. Boxplots showing distribution of:

11. Nitrogen compounds at low flows (June 2000-September 2004) and high flows (April 2002-November 2004) at (a) Cypress Creek and (b) East Fork San Jacinto River near Houston, Texas

12. Orthophosphate phosphorus, dissolved phosphorus, and total phosphorus at low flows (June 2000-September 2004) and high flows (April 2002-November 2004) at (a) Cypress Creek and (b) East Fork San Jacinto River near Houston, Texas

13. Suspended sediment at low flows (June 2000-September 2004) and high flows (April 2002-November 2004) at (a) Cypress Creek and (b) East Fork San Jacinto River near Houston, Texas

14. Organic carbon at low flows (June 2000-September 2004) and high flows (April 2002November 2004) at (a) Cypress Creek and (b) East Fork San Jacinto River near Houston, Texas 


\section{Tables}

1. Subbasin characteristics for Lake Houston near Houston, Texas .......................... 2

2. Data-collection sites at Lake Houston, Cypress Creek, and East Fork San Jacinto River, near Houston, Texas, 2000-2004 ........................................... 6

3. Summary of statistical tests used to indicate water-quality trends at Lake Houston, near Houston, Texas, 1990-2004.

4. Statistical summary of nitrogen compounds, phosphorus, suspended sediment, organic carbon, chlorophyll-a, and selected pesticides for sites AC, EC, and FC combined, Lake Houston near Houston, Texas, February 2000-September 2004.

5. Summary of pesticide detections at sampling sites in Lake Houston, Cypress Creek, and East Fork San Jacinto River, near Houston, Texas, 2000-2004 ......................... 17

6. Summary of minimum, median, and maximum loads of selected constituents at low flows and high flows in Cypress Creek near Houston, Texas, 2000-2004 ........................ 25

7. Summary of minimum, median, and maximum loads of selected constituents at low flows and high flows in East Fork San Jacinto River near Houston, Texas, 2000-2004 ............... 25

8. Summary of minimum, median, and maximum yields of selected constituents at low flows and high flows in Cypress Creek near Houston, Texas, 2000-2004 ......................... 26

9. Summary of minimum, median, and maximum yields of selected constituents at low flows and high flows in East Fork San Jacinto River near Houston, Texas, 2000-2004

10. Summary of statistical tests for trends in nitrite plus nitrate, dissolved phosphorus, dissolved organic carbon, chlorophyll-a, and diazinon at three sites in Lake Houston near Houston, Texas, 1990-2004 
Blank Page 


\title{
Water-Quality Assessment of Lake Houston Near Houston, Texas, 2000-2004
}

\author{
By Debra A. Sneck-Fahrer, Matthew S. Milburn, Jeffery W. East, and Jeannette H. Oden
}

\section{Abstract}

Lake Houston is a major source of public water supply and recreational resource for the Houston metropolitan area, Texas. Water-quality issues of potential concern for the lake have included nutrient enrichment (orthophosphorus, total phosphorus, nitrite plus nitrate) and aquatic life use (dissolved oxygen). The U.S. Geological Survey, in cooperation with the City of Houston, collected water samples from three sites in Lake Houston and from two streams that discharge to the lake during 2000-2004. Nitrogen compounds, phosphorus, suspended sediment, organic carbon, turbidity, chlorophyll- $a$, and selected pesticide compounds in water were assessed for all sites. Waterquality conditions of the lake and inflow streams were assessed, and loads and yields were computed for selected constituents in the streams. Selected constituents from samples collected in Lake Houston during 1990-2004 were tested for trends. The three sites sampled in Lake Houston characterized water available to the City of Houston pumping station (site AC), water entering the lake from the largely rural eastern subbasin (site EC), and water entering the lake from the more urbanized, western subbasin (site FC). Most constituent concentrations were largest at site FC, smallest at site EC, and intermediate at site AC. Organic nitrogen was the dominant form of nitrogen in samples collected at all sites. Nitrite plus nitrate concentrations were largest at site FC. Total phosphorus concentrations in all samples were larger than that recommended by the U.S. Environmental Protection Agency to limit aquatic growth in reservoirs. There was a wide range in suspended-sediment concentrations and turbidity in the lake. Twelve pesticides were detected. Atrazine and its breakdown product, 2-chloro-4-isopropylamino-6-amino-s-triazine (CIAT), were the most commonly detected pesticides; concentrations of atrazine were larger than the U.S. Environmental Protection Agency maximum contaminant level of 3.0 micrograms per liter in two samples at site FC. The relative contributions to the water quality of Lake Houston from the eastern and western subbasins were examined by collecting water samples in Cypress Creek and East Fork San Jacinto River. Nitrate and pesticide concentra- tions were larger in Cypress Creek than in East Fork San Jacinto River. In Cypress Creek, nitrate was the primary form of nitrogen at low flows. Atrazine exceeded 3.0 micrograms per liter in three of 17 samples, with the maximum measured concentration of 21.3 micrograms per liter. In East Fork San Jacinto River, organic nitrogen was the primary form of nitrogen. Atrazine was detected in six of 15 samples. The maximum atrazine concentration was 0.233 microgram per liter. Constituent yields allowed direct comparison of loads from Cypress Creek and East Fork San Jacinto River. In Cypress Creek, storm yields of nitrite plus nitrate nitrogen for high flows ranged from 8 to 45 pounds per square mile per day; in East Fork San Jacinto River, the maximum storm yield for high flows was 1.47 pounds per square mile per day. At low flows, the median daily yield of dissolved phosphorus from Cypress Creek was 84 times larger than the median daily yield from East Fork San Jacinto River; at high flows, it was 16 times larger. At high flows, the maximum daily yield of atrazine from Cypress Creek was 460 times larger than the maximum daily yield at high flows from East Fork San Jacinto River. The concentrations of most constituents at Lake Houston sites showed no trend during 1990-2004; however, significant trends overall or for particular seasons, or both, were detected at some sites for nitrite plus nitrate, dissolved phosphorus, dissolved organic carbon, chlorophyll- $a$, and diazinon (2000-2004 data only for diazinon).

\section{Introduction}

Houston, Texas, is the fourth-largest city and greater Houston the tenth-largest metropolitan area in the Nation, with an estimated population of about 5 million people in 2003 (Texas State Data Center, 2004). Historically, ground water has been the major source of potable water. However, development of this resource has contributed to lowered ground-water levels and land-surface subsidence (Kasmarek and Houston, 2005). These effects, in part, have led water managers to engineer a gradual transition away from ground water to surface water as the principal source of public supply. Currently (2005), a little 


\section{Water-Quality Assessment of Lake Houston Near Houston, Texas, 2000-2004}

more than one-half of Houston's water supply comes from surface water (LJA Engineering \& Surveying, Inc., 2000). The overall goal is to increase the use of surface water to supply not less than 80 percent of the total demand by 2030 (HarrisGalveston Coastal Subsidence District, 1999).

Lake Houston is a major source of public water supply and recreational resource for the Houston metropolitan area. Because of its proximity to Houston, the possible effects of urbanization on the quality of inflows to the lake and on the lake have been of concern to water managers. In accordance with Federal Clean Water Act requirements, the Texas Commission on Environmental Quality compiled an inventory of water-body assessments throughout the State that lists those water bodies that are impaired (do not meet applicable water-quality standards) or threatened (are not expected to meet applicable waterquality standards in the near future) (Texas Commission on Environmental Quality, 2002). Lake Houston (segment 1002) was not on the State of Texas 2002 list (known as the 303(d) list) of impaired water bodies. However, it was listed with "concerns" for nutrient enrichment (orthophosphorus, total phosphorus, nitrite plus nitrate nitrogen) and aquatic life use (dissolved oxygen). Information describing the current (2005) status and trends of the water quality of Lake Houston and its inflow tributaries will help water managers assess potential sources of contaminants and their effects on the lake.

Beginning in 1983, the U.S. Geological Survey (USGS), in cooperation with the City of Houston, has collected water-quality and stage data at Lake Houston, as well as water-quality and discharge data for its major tributaries. These data, collected through most of the 1990s, were summarized and interpreted (Liscum and others, 1999) and used to develop a two-dimensional water-quality model of the lake (Liscum and East, 2000). On the basis of findings of these studies, eutrophication has not been a major problem in the lake. However, the findings indicated that sufficient concentrations of nutrients (nitrogen and phosphorus) were present to cause problematic algal blooms. An analysis of sediment-core samples from Lake Houston to identify historical water-quality trends (Van Metre and SneckFahrer, 2002) indicated the need for further study of the effects of urbanization on Lake Houston. To address this need, the USGS, in cooperation with the City of Houston, did a waterquality assessment of Lake Houston and selected major inflow tributaries.

\section{Purpose and Scope}

The purpose of this report is to (1) assess concentrations of nitrogen, phosphorus, suspended sediment, organic carbon, turbidity, chlorophyll- $a$, and pesticides in Lake Houston for 20002004; (2) summarize data for 2000-2004 and compute loads and yields of selected constituents from two stream inflow sites; and (3) examine possible trends in the water quality of Lake Houston on the basis of data for 1990-2004. Water-quality data presented in this report were collected during February 2000November 2004 at five sites. Three sampling sites were in Lake
Table 1. Subbasin characteristics for Lake Houston near Houston, Texas (modified from Liscum and others, 1999, table 1).

$\left[\mathrm{mi}^{2}\right.$, square miles $]$

\begin{tabular}{|c|c|c|}
\hline Subbasin watershed & $\begin{array}{c}\text { Drainage } \\
\text { area } \\
\left(\mathrm{mi}^{2}\right)\end{array}$ & $\begin{array}{c}\text { Percent of } \\
\text { drainage } \\
\text { basin }\end{array}$ \\
\hline \multicolumn{3}{|l|}{ Eastern subbasin } \\
\hline East Fork San Jacinto River & 404 & 14.3 \\
\hline Peach Creek & 151 & 5.3 \\
\hline Caney Creek & 222 & 7.9 \\
\hline Luce Bayou & 210 & 7.4 \\
\hline \multicolumn{3}{|l|}{ Western subbasin } \\
\hline West Fork San Jacinto River & 998 & 35.3 \\
\hline Spring Creek & 453 & 16.1 \\
\hline Cypress Creek & 305 & 10.8 \\
\hline \multirow[t]{2}{*}{ Lake Houston area ${ }^{1}$} & 82 & 2.9 \\
\hline & 2,825 & 100 \\
\hline
\end{tabular}

\footnotetext{
${ }^{1}$ That part of the watershed surrounding Lake Houston downstream from tributary inflows.
}

Houston; the remaining sites were on two of the seven inflow streams to the lake. Data collected during this study were published in annual USGS Texas water-data reports (Gandara and others, 2001; Gandara, 2002, 2003, 2004; Aragon Long and others, 2005).

\section{Description of the Study Area}

Lake Houston is located about 25 miles east-northeast of downtown Houston, Texas (fig. 1). It was constructed in 1954 by the City of Houston as a public water supply for Houston and Baytown, as well as for local irrigation. The normal capacity of Lake Houston was computed to be 133,990 acre-feet in 1994 (Texas Water Development Board, 2004). Liscum and East (2000) reported the mean depth of the lake to be 12 feet with a maximum depth of about 50 feet. Computed theoretical residence time for water entering Lake Houston varies with flow conditions from a maximum of about 400 days during extreme low flows to a minimum of about 0.5 day during extreme high flows (Liscum and East, 2000, p. 3). During the 2000-2004 study period, the maximum annual mean residence time was estimated to be about 176 days in water year 2000; the minimum was about 24 days in water year 2004 . The average residence time during the entire study period was 61 days.

The drainage basin for Lake Houston (fig. 1) includes parts of seven counties, including large areas of densely populated Harris and Montgomery Counties. The drainage basin can be divided into an eastern subbasin and a western subbasin that comprise four and three stream watersheds, respectively, plus the area immediately surrounding the lake (table 1). The 


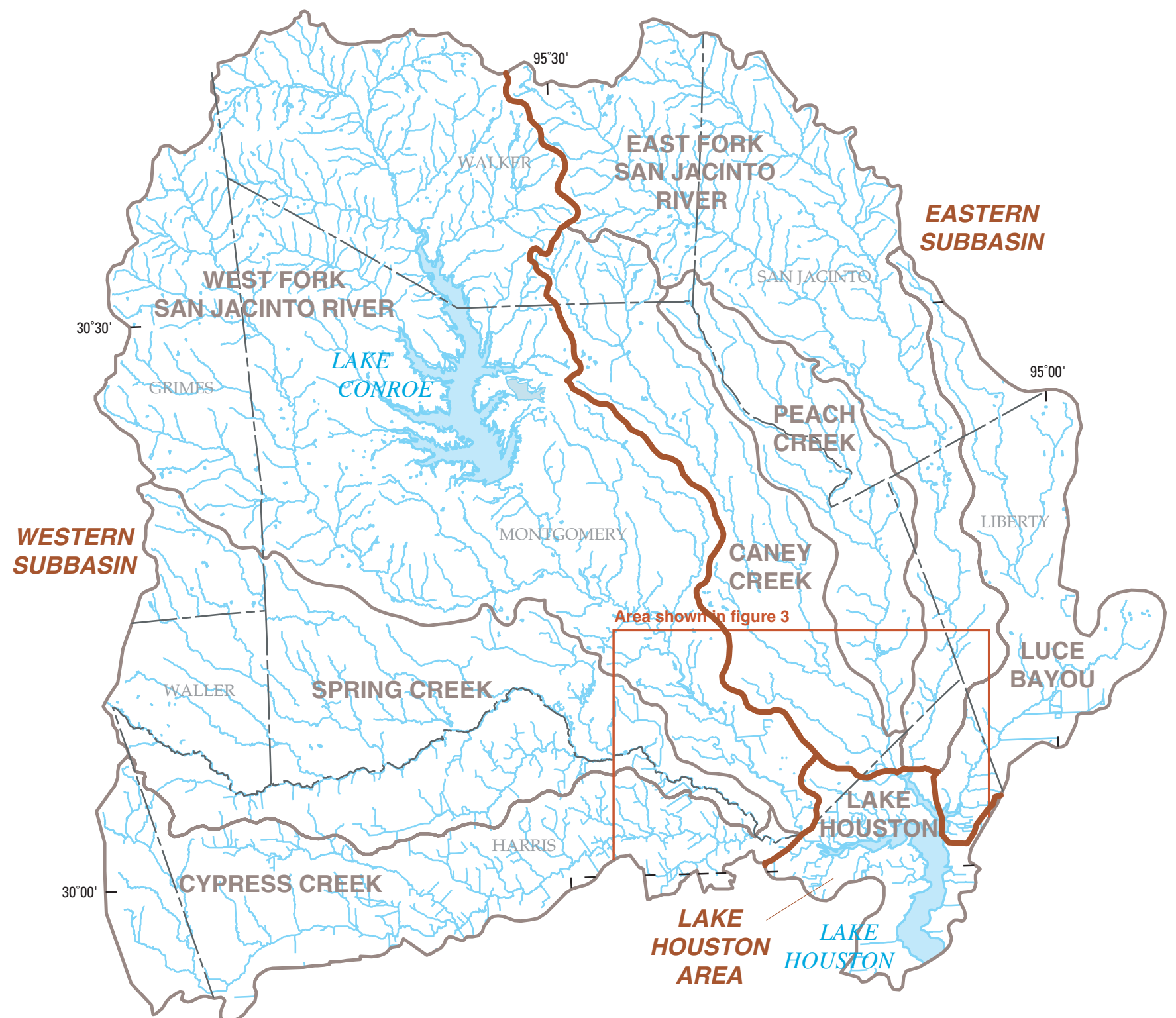

Base from Houston-Galveston Area Council, 2004 Lake Houston watershed, 1:602,933

Universal Transverse Mercator projection, Zone 15

\section{EXPLANATION}

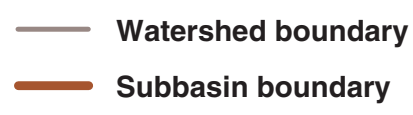

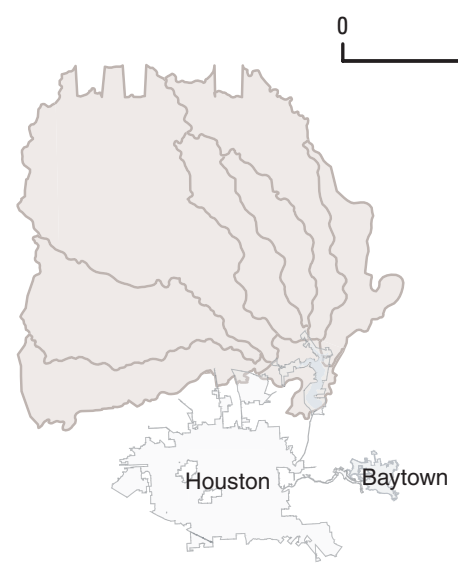

Location of study area and Houston, Texas

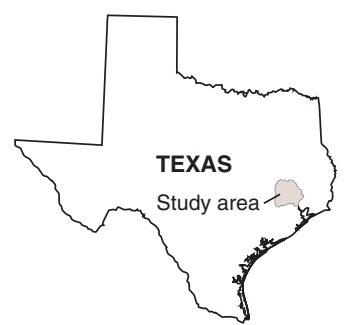

LOCATION MAP

Figure 1. Lake Houston drainage basin (study area) near Houston, Texas. 


\section{Water-Quality Assessment of Lake Houston Near Houston, Texas, 2000-2004}

Cypress Creek watershed in the Lake Houston western subbasin is the most densely populated of the stream watersheds that drain to Lake Houston. The total population of the Cypress Creek watershed in 2000 (Patrick Horton, Houston-Galveston Area Council, written commun., 2005) was about 263,000 people. About 13 percent of the watershed had a population density of 650 to 1,750 people per square mile, and about 0.3 percent of the watershed had a population of density of 1,760 to 5,930 people per square mile. East Fork San Jacinto River in the Lake Houston eastern subbasin is the least densely populated of the stream watersheds that drain to Lake Houston. The total population of the East Fork San Jacinto River watershed in 2000 was about 44,700 people; less than 1.4 percent of the watershed had the maximum population density of 650 to 1,750 people per square mile.

Appreciable differences in land cover characterize the Lake Houston drainage basin (fig. 2). The area that comprises land-cover types related to an increased potential for nutrients and pesticide compounds in storm runoff (developed and cultivated) is about three times greater in the western subbasin than in the eastern subbasin (Houston-Galveston Area Council, 2004). Land cover classified as developed (urban development) in the western subbasin is about 78 percent greater than that in the eastern subbasin. The Cypress Creek watershed has an area of 305 square miles. The primary land-cover type in that watershed in 2002 (fig. 2) was grassland (50 percent), consisting of fields for hay, cattle grazing, and a small amount of agriculture. Woodland (31 percent) was the second-largest land-cover type. About 5 percent of the area in the basin was classified as highintensity developed. The East Fork San Jacinto River watershed has an area of 404 square miles with most of the area classified as woodland (79 percent), followed by grassland (about 14 percent). The largest concentrations of urban development in the entire Lake Houston drainage basin are in the area immediately surrounding Lake Houston.

The climate in the study area is classified as humid subtropical (Texas State Climatologist, 2004), characterized by cool and temperate winters, long and hot summers, high relative humidity, and prevailing winds from the south and southeast. During 2000-2004, annual precipitation ranged from 45.5 to 82 inches at Intercontinental Airport (IAH), Houston (National Oceanic and Atmospheric Administration, 2005), in the Cypress Creek watershed, about 8 miles west of Lake Houston. Temperatures ranged from a mean of about 55.5 degrees Fahrenheit $\left({ }^{\circ} \mathrm{F}\right)$ in the winter (December-February) to a mean of $83{ }^{\circ} \mathrm{F}$ in the summer (June-August), with maximum temperatures during the summer commonly higher than $90^{\circ} \mathrm{F}$.

\section{Sources and Implications of Nitrogen, Phosphorus, Suspended Sediment, Organic Carbon, Turbidity, Chlorophyll-a, and Pesticides}

Nitrogen compounds naturally occur in the environment, usually small amounts in surface water, and include nitrate, nitrite, organic, or ammonia nitrogen. Nitrate nitrogen is the most common nitrogen compound in water (Hem, 1985). The national background concentration of nitrate nitrogen in streams is about 0.6 milligram per liter $(\mathrm{mg} / \mathrm{L})$ (U.S. Geological Survey, 1999, p. 34). Elevated nitrite and ammonia nitrogen concentrations might indicate wastewater input (U.S. Geological Survey, 1999).

Large concentrations of nitrate or nitrite in drinking water might result in infant methemoglobinemia (inability of the blood to absorb oxygen), which causes shortness of breath and blueness of the skin (U.S. Environmental Protection Agency, 1999). In addition, Weyer and others (2001) identified a correlation between nitrate in drinking water and bladder cancer in women. The U.S. Environmental Protection Agency (USEPA) (1999) has set maximum contaminant levels (MCLs) in drinking water (the enforceable standard) of $1 \mathrm{mg} / \mathrm{L}$ nitrite nitrogen and $10.0 \mathrm{mg} / \mathrm{L}$ nitrate nitrogen. There is no USEPA MCL for ammonia nitrogen.

Total phosphorus includes dissolved forms as well as phosphorus that is attached to sediment particles and in living organisms like algae and bacteria. Dissolved phosphorus includes orthophosphate and organic phosphorus. Phosphorus as phosphate is an essential nutrient for freshwater plants (Hem, 1985). Phosphorus is introduced into water through a variety of sources that include animal waste, domestic and wild waterfowl, tree leaves, and fallout from the atmosphere. In addition, phosphate is an ingredient of many detergents and is found in human waste. The national background concentration of total phosphorus in streams is about $0.1 \mathrm{mg} / \mathrm{L}$ (U.S. Geological Survey, 1999, p. 34).

Large phosphorus concentrations have been associated with eutrophication or aging of waters, especially lakes and reservoirs (U.S. Environmental Protection Agency, 1986). Total phosphorus concentrations larger than $0.025 \mathrm{mg} / \mathrm{L}$ can stimulate excessive growth of algae and nuisance plants in lakes and reservoirs. Excessive algal growth can result in undesirable taste and odor of the water, as well as interference with coagulation in water-treatment plants. The USEPA has recommended a limit of $0.05 \mathrm{mg} / \mathrm{L}$ total phosphorus for a stream where it enters any lake or reservoir and $0.025 \mathrm{mg} / \mathrm{L}$ within the lake or reservoir as a goal to limit undesirable aquatic growth.

Suspended sediment is carried to a reservoir with inflowing streams and generally increases with increased streamflow. During storms, large volumes of sediment can be added to streams from surface runoff, especially in areas where the landscape has been disturbed. Urbanized areas, where precipitation is quickly channeled to ditches and storm sewers, add substantial runoff to receiving streams and increase the potential for erosion of streambeds and banks. Sediment is a concern because it can fill reservoirs and inhibit sunlight penetration for aquatic plants. Phosphorus, bacteria, metals, and many organics tend to adsorb to fine silt and clay (Hem, 1985; U.S. Geological Survey, 1999).

All natural waters contain organic material. When compared with inorganic carbon, the amount of carbon contributed by organic material is very small (Hem, 1985); however, organic contributions can have an appreciable effect on the 


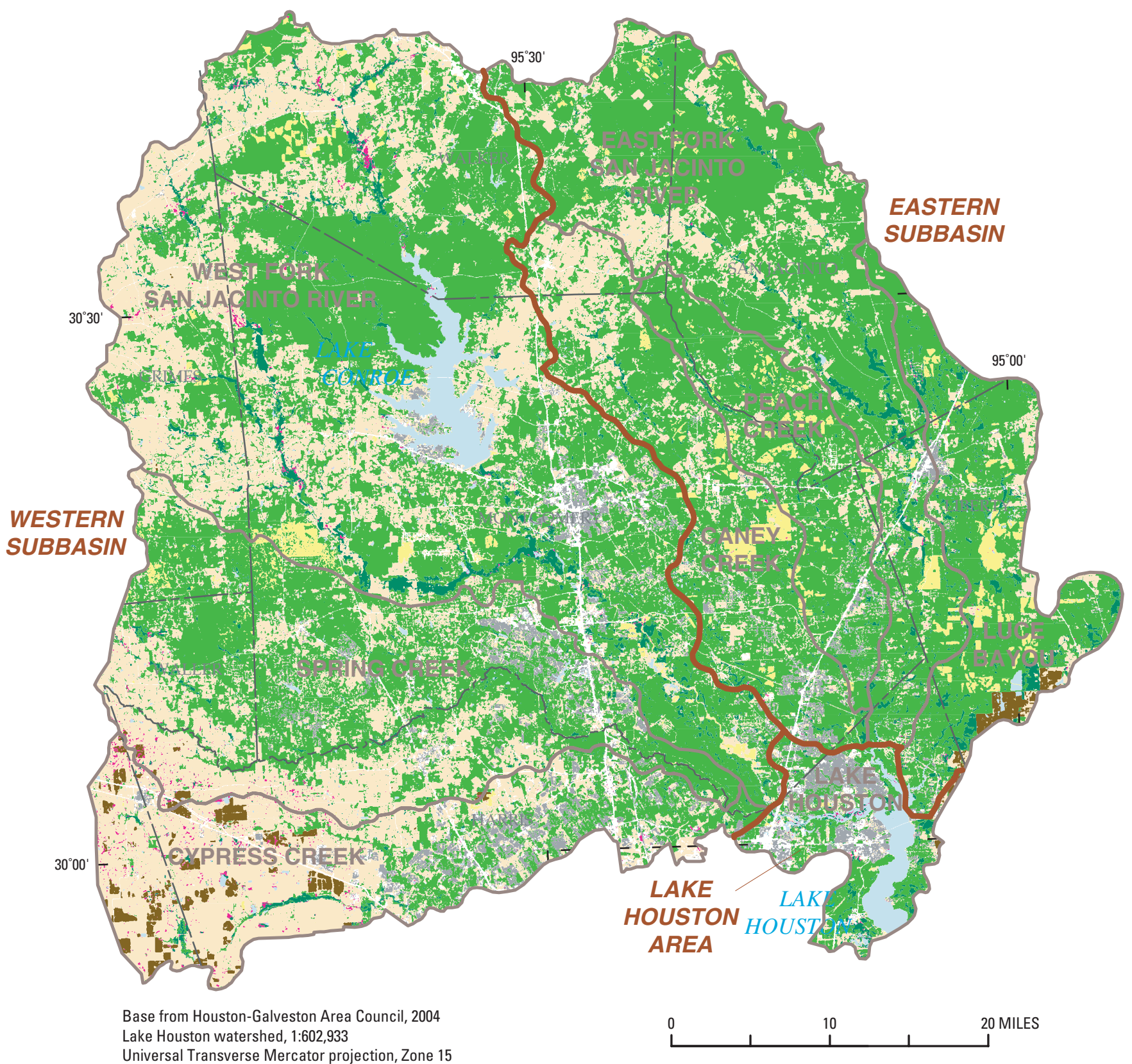

\section{EXPLANATION}

Land cover classification

Low-intensity developed

High-intensity developed

Cultivated land

Grassland

Woodland

Open water

Woody wetland

Non-woody wetland

Bare/transitional land

Watershed boundary

Subbasin boundary

Figure 2. Land-cover distribution in the Lake Houston drainage basin near Houston, Texas, 2002. 
6 Water-Quality Assessment of Lake Houston Near Houston, Texas, 2000-2004

Table 2. Data-collection sites at Lake Houston, Cypress Creek, and East Fork San Jacinto River near Houston, Texas, 2000-2004.

[USGS, U.S. Geological Survey; $\mathrm{mi}^{2}$, square mile]

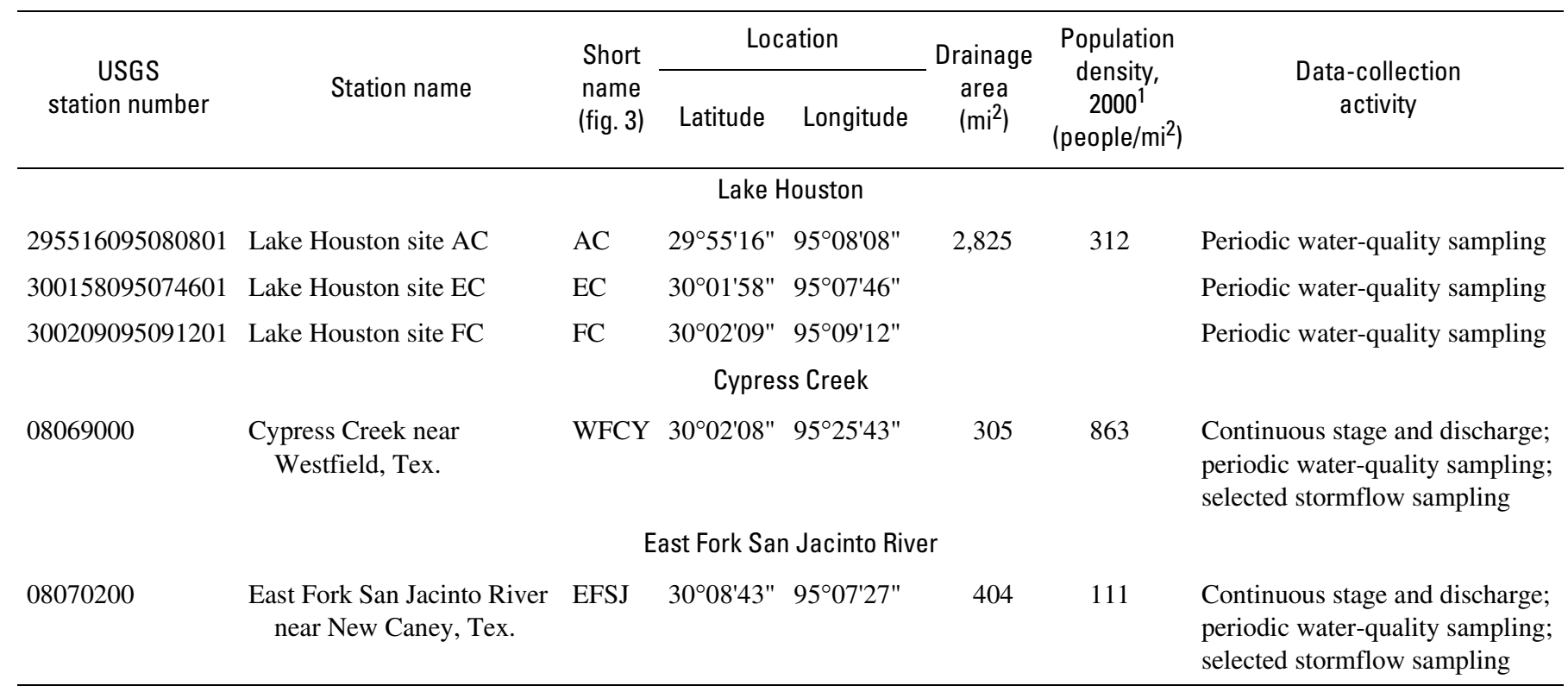

${ }^{1}$ Source: Patrick Horton, Houston-Galveston Area Council, written commun., 2005.

chemical properties of surface water, such as the reduction and transport of metal oxides (Hem, 1985). Sources of organic carbon include decayed organic material, living organisms found in the water, and sewage. Dissolved and total organic carbon concentrations, along with ultraviolet light absorbance, can give an indication of the potential for formation of trihalomethanes (THMs) in water chlorinated for consumption (Fujii and others, 1998; Potter and Wimsatt, 2003). THMs are classified by the USEPA as probable human carcinogens (U.S. Environmental Protection Agency, 1999).

Although turbidity is not directly associated with adverse health effects in humans, it is used as an indicator of the possible presence of disease-causing organisms. These organisms include bacteria, as well as viral and protozoan pathogens. LeChevallier and others (1981) showed that turbidity particles shield bacteria from the effects of disinfection during water treatment. The USEPA has established an MCL for turbidity in drinking water of 5 nephelometric turbidity units (NTUs). Treatment systems that process surface water are required to have less than 1 NTU in 95 percent of samples (U.S. Environmental Protection Agency, 1999).

Chlorophyll- $a$ is a photosynthetic pigment found in algae and other green plants. The concentration of chlorophyll- $a$ is used to estimate the amount of phytoplankton or periphyton in a water body (Porter and others, 1993). An excessive amount of algae is a direct cause of esthetic degradation (color, taste, and odor) of a lake or reservoir, and might be a major part of the total turbidity. Decomposition of dead algal cells and other organic matter in a reservoir can increase oxygen loss, releasing iron, manganese, and nutrients, which in turn, supports further biological growth (Thornton and others, 1990).

Pesticides, which include herbicides, insecticides, and fungicides, are used widely in the United States. In urban areas, the most commonly detected compounds include atrazine, simazine, and diazinon (U.S. Geological Survey, 1999). Atrazine and simazine commonly are used for maintenance of roadsides, commercial areas, lawns, and gardens. Diazinon is an insecticide used for homes and gardens. The USEPA has established either MCLs or Health Advisories (HAs) (contaminant goal) for these compounds. For atrazine, the MCL is 3.0 micrograms per liter $(\mu \mathrm{g} / \mathrm{L})$; for simazine, the MCL is $4.0 \mu \mathrm{g} / \mathrm{L}$; for diazinon, the HA is $6.0 \mu \mathrm{g} / \mathrm{L}$ (U.S. Environmental Protection Agency, 2004).

\section{Acknowledgments}

The authors sincerely appreciate the assistance of Patrick Horton, Houston-Galveston Area Council, who provided geographic information system feature datasets used in this report, and Richard Kiesling, Franklin Heitmuller, and Reed Green, USGS, for their critical reviews of the manuscript.

\section{Methods of Study}

Water-quality samples were collected at three sites in Lake Houston, one site on Cypress Creek, and one site on East Fork San Jacinto River (fig. 3, table 2). Results from lake sampling 


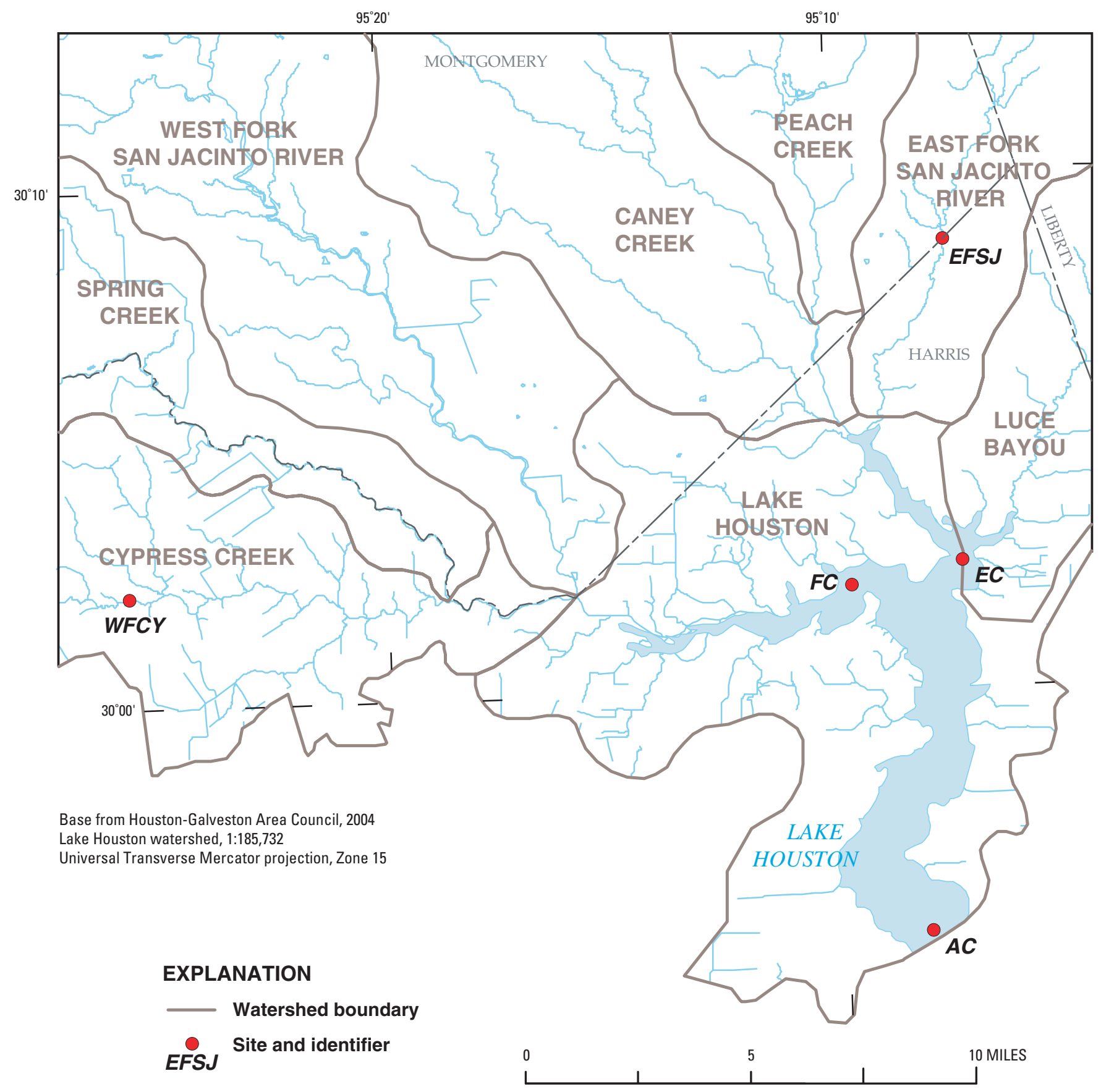

Figure 3. Data-collection sites at Lake Houston, Cypress Creek, and East Fork San Jacinto River near Houston, Texas, 2000-2004.

sites were used to characterize water available to the City of Houston pumping station (site AC); water entering the lake from largely rural, eastern watersheds (site EC); and water entering the lake from the more urbanized, western watersheds (site FC). Results from Cypress Creek were used to represent water quality of inflows from the western subbasin; and results from East Fork San Jacinto River, those from the eastern subbasin. One-hundred eleven physical properties and constituents were measured at each site; concentrations of additional constit- uents were measured at some sites where possible. The properties and constituents were arranged into six groups: (1) field measurements and physical properties; (2) major cations and anions; (3) nutrients; (4) biological constituents; (5) trace elements (metals); and (6) pesticides. These are documented in the annual USGS Texas water-data reports noted in the Purpose and Scope section. Summary statistics for all field measurements, physical properties, and chemical constituents at each site are in the appendixes. 


\section{Data Collection and Analysis}

All Lake Houston sampling sites (fig. 3) were located in the thalwegs of pre-existing stream channels. Each site was sampled three times annually during February 2000-September 2004 to characterize winter (November-February), spring (March-June), and summer (July-October) conditions. Waterquality samples were collected at two stream inflow sites. Each inflow site was sampled two times per year during June 2000September 2004 at low-flow conditions, on most occasions concurrent with sampling at Lake Houston. Beginning in the 2002 water year (October 2001-September 2002), additional samples were collected at each stream inflow site during high flows associated with storms; eight high-flow samples were collected at Cypress Creek (site WFCY), and five high-flow samples were collected at East Fork San Jacinto River (site EFSJ) during April 2002-November 2004.

At each lake site (FC, EC, and $\mathrm{AC}$ ), water was sampled at specific depths below the surface. Water was pumped from each sampling point through acid-washed tubing using a peristaltic pump. Specific conductance, $\mathrm{pH}$, water temperature, and dissolved oxygen were measured from pumped water at each site at the top (1 foot below the surface), at 10-foot increments, and at the bottom (1 foot above the bottom). Water samples for subsequent analysis of major ions, nutrients, biological constituents, and trace elements were collected at the 1-foot depth only. Water samples for analysis of pesticides were collected separately from three depths (top, mean depth of the site, and bottom) using a thief-type sampler (Lane and others, 2003). Lakewater transparency was measured using a standard Secchi disk.

At each stream inflow site (WFCY and EFSJ), water samples were collected during low-flow conditions using a handheld sampler. Depth-integrated subsamples were collected at equally spaced vertical sections across the stream (Shelton, 1994). Measurements of specific conductance, $\mathrm{pH}$, water temperature, and dissolved oxygen were made at the same vertical sections used for sample collection. During high flows, water samples were collected with an automated point-sampler that collected discrete samples throughout the storm. The flowweighted samples were composited to obtain average high-flow constituent concentrations. Grab samples were collected for bacteria and pesticide analyses as single, discrete samples. Stream discharge was recorded at the time of each sample collection by continuous-recording streamflow-gaging stations at each site.

Fecal indicator bacteria analyses were done by membrane filtration (Myers and Wilde, 2003) at the USGS Texas Water Science Center-Houston office. Suspended-sediment concentrations were analyzed at the USGS Louisiana Water Science Center sediment laboratory (Guy, 1969). All other analyses were done by the USGS National Water Quality Laboratory in Denver, Colorado (Wershaw and others, 1987; Fishman and others, 1994; Sandstrom and others, 2001). Improvements in analytical methods and instrumentation occurred during the study period, in some cases resulting in the reduction of a minimum reporting level (MRL).

\section{Quality Assurance and Quality Control}

All sample-collection and processing procedures followed are described by Shelton (1994). Data management and documentation were done in accordance with USGS national standards (U.S. Geological Survey, variously dated) to ensure the quality, precision, accuracy, and completeness of collected data. All participants were properly trained and experienced and followed procedures outlined in these documents.

Quality control (QC) samples, which consisted of field blanks, matrix spikes, and replicate samples, were used to determine the extent to which contamination, matrix effects, and measurement variability affected the analytical results (Mueller and others, 1997). In addition to the field QC samples, periodic equipment blanks of deionized water certified to be free of organic and inorganic compounds were used to demonstrate that equipment used for sample collection and processing were not a source of contamination. About 10 percent of the total samples collected during February 2000-November 2004 were field-processed QC samples. Further explanation of QC sample types and their use are described by Mueller and others (1997).

Five field blanks were collected and processed on-site, immediately before an associated environmental sample, to determine potential contamination from field activities associated with data collection. Very low levels of some major ions and metals were detected in two of the five field blanks in concentrations that generally were less than 5 percent of the concentration measured in the environmental sample. One water sample was spiked with known volumes and concentrations of pesticide compounds. Laboratory recoveries from the sample were within method-acceptance ranges for all constituents. Eight replicate samples were collected. Replicate samples were compared to the corresponding environmental samples by calculating the relative percentage difference (RPD) for each constituent. The RPD, which generally was less than 10 percent, was calculated using the equation

$$
R P D=\left|S_{1}-S_{2}\right| /\left(\left(S_{1}+S_{2}\right) / 2\right) \times 100,
$$

where

$S_{1}=$ concentration from environmental sample; and

$S_{2}=$ concentration from replicate sample.

The RPD exceeded 10 percent for nine of 108 sample pairs of major ions and for 17 of 171 sample pairs of trace metals. RPDs larger than 10 percent occurred for four of nine sample pairs associated with organic carbon (total unfiltered organic carbon) and for two of 49 sample pairs associated with nitrogen (ammonia plus organic nitrogen). The RPD exceeded 10 percent primarily when constituent concentrations were very small so that small variability in analytical results caused relatively large RPDs. Because of inherent heterogeneity of some constituents in water, variability of replicate sample collection, sample processing, and laboratory analysis, differences in concentrations caused by sampling imprecision (field) or analytical procedures and instrumentation (laboratory) generally were inseparable. 


\section{Load and Yield Computations}

A constituent load is the mass of a given constituent that passes a stream cross section per unit time. Two types of loads were computed for this study. For all samples that were collected during low flows and for pesticide analyses during high flows, the discharge used to compute the load was an instantaneous value at the time of sample collection; therefore the instantaneous load is appropriate only for that time, although it was assumed to represent mass transported over a 24-hour period, or daily load. The concentration used was the measured valued for the sample. For samples of nitrogen, phosphorus, orthophosphate, suspended sediment, and organic carbon that were collected over the duration of a storm (high flow) with an automatic sampler, load was computed using the mean stream discharge for the period of sample collection (event mean) and the flow-weighted concentration. Loads computed for highflow samples represent mass transported for entire storms (which can last from a few hours to a few days) on a daily basis. Because the relatively small number of samples could not adequately represent stream water quality over extended periods, annual loads were not computed.

Daily load was computed using the equation

$$
\mathrm{L}=\mathrm{Q} \times \mathrm{C} \times \mathrm{K}
$$

(Terrio, 1995, p. 38), where

$\mathrm{L}=$ constituent load, in pounds per day;

$\mathrm{Q}=$ discharge, in cubic feet per second (instantaneous for low flow, event-mean for high flow);

$\mathrm{C}=$ constituent concentration, in milligrams per liter or micrograms per liter (single sample for low flow, flow-weighted for high flow); and

$\mathrm{K}=$ conversion factor of 5.395 for concentrations reported in milligrams per liter; 0.005395 for concentrations reported in micrograms per liter.
A measure of load-producing characteristics of a watershed is the yield. Daily yield was computed by dividing the daily load of a constituent by the upstream drainage area:

$$
\mathrm{Y}=\mathrm{L} / \mathrm{DA} \text {, }
$$

where

$\mathrm{Y}=$ constituent yield, in pounds per square mile per day;

$\mathrm{L}=$ constituent load, in pounds per day; and

$\mathrm{DA}=$ area of contributing watershed, in square miles.

As with loads, yields are presented for low flows and high flows in the two tributaries. High-flow yields can represent storms of a few hours to a few days, but yields are normalized to a daily basis to allow comparisons among sites and between watersheds.

\section{Trend Testing}

Trends in Lake Houston water quality were based on data collected during earlier periods of sample collection (1990-99) (Liscum and others, 1999), in addition to data collected during this study. To differentiate potential seasonal fluctuations in concentrations of nutrients, chlorophyll- $a$, and pesticides, each annual cycle was divided into three periods (winter, spring, and summer), coincident with the timing of samples collected during 2000-2004. To avoid bias, if a site was sampled more than once during a single period of 1 year, the median concentration of each constituent was used for that period. A total of 126 samples (42 samples at each of the three lake sites) was used for trend analysis.

To test whether concentrations increased or decreased over time, time-series graphs and nonparametric statistical techniques (Helsel and Hirsch, 1992) (table 3) were used. Seasonal Kendall tests, which account for seasonal variations so that all the data for a site collectively can be trend tested, were done.

Table 3. Summary of statistical tests used to indicate water-quality trends at Lake Houston near Houston, Texas, 1990-2004 (modified from Helsel and Hirsch, 1992).

\begin{tabular}{|c|c|c|c|}
\hline $\begin{array}{l}\text { Statistical } \\
\text { test }\end{array}$ & Use & Decision rule & $\begin{array}{l}\text { Significance } \\
\text { level }(\mathrm{p}) \\
\text { to reject null } \\
\text { hypothesis, } \mathrm{H}_{0}\end{array}$ \\
\hline $\begin{array}{c}\text { Two-sample } \\
\text { Wilcoxon } \\
\text { rank-sum }\end{array}$ & $\begin{array}{l}\text { Comparison of two sets of observations to } \\
\text { determine if one set tends to produce larger } \\
\text { or smaller values than the other set }\end{array}$ & $\begin{array}{l}\mathrm{H}_{0} \text { : The relative distribution of two populations is the same } \\
\mathrm{H}_{\mathrm{A}} \text { : The relative distribution of two populations is different }\end{array}$ & $\mathrm{p} \leq .05$ \\
\hline
\end{tabular}

[p, p-value ${ }^{1} ; \mathrm{H}_{0}$, null hypothesis; $\mathrm{H}_{\mathrm{A}}$, alternative hypothesis; $\leq$, less than or equal to]

\footnotetext{
${ }^{1}$ The p-value is the probability of obtaining computed test statistic, or one even less likely, when null hypothesis is true (Helsel and Hirsch, 1992, p. 108).
} 
Trends in the data for each site separated by season were identified using Kendall's tau tests. The tests provide p-values (attained significance levels), which in these tests indicate the strength of the evidence for a trend: the smaller the p-value, the stronger the evidence for a trend. Trends commonly are considered significant if the p-value is about .05 or less.

To test whether water-quality conditions differed at different sites, Wilcoxon rank-sum tests were used (Helsel and Hirsch, 1992). This test compares two sets of observations to determine if one site tends to yield larger or smaller values than the other site. No assumptions are made about the distributions of the data. The null hypothesis (what is assumed to be true before the test) for this test was that neither of the two datasets (sites) tends to yield larger or smaller values than the other site- that is, the two datasets are not significantly different. As with the seasonal Kendall and Kendall's tau tests, the Wilcoxon rank-sum test provides a p-value. In this test, the p-value indicates the strength of the evidence that the two datasets are different; they commonly are considered significantly different if the p-value is about .05 or less.

\section{Water-Quality Assessment of Lake Houston}

Patterns of chemical and biological constituents in Lake Houston are affected by sedimentation and the water quality of inflowing streams. Patterns periodically might be altered by changes in residence time of water within the lake and mixing of the water column because of wind and solar heating. In general, conditions at the upgradient end of Lake Houston (sites EC and FC) (fig. 3) are dominated by inflowing streams with deposition of coarse-grained particles; as water moves through the lake, lacustrine (lake-like) characteristics became increasingly important, and sediment particle size steadily decreases to that of fine clay near the dam. The general pattern of chemical constituents supplied to the lake is one in which streams in the western subbasin provide larger concentrations of nutrients and sediment to Lake Houston than streams in the eastern subbasin. Chemical concentrations for most constituents were largest at site FC, smallest at site EC, and intermediate at site AC. Nutrients and turbidity, which have opposite effects on algal growth, were both largest at site FC. Statistical results of field measurements, physical properties, and constituents for each datacollection site are shown in appendixes 1-3.

\section{Ambient Conditions, 2000-2004}

Organic nitrogen was the dominant form of nitrogen in samples collected in Lake Houston. Total phosphorus concentrations, in all samples, were larger than the concentration $(0.025 \mathrm{mg} / \mathrm{L})$ suggested by the USEPA to limit aquatic growth. There was a wide range of turbidity and suspended-sediment concentrations, which reflects the shallow conditions of the lake and periodic turbulence caused by wind, as reported previously by Liscum and East (2000). Overall, chlorophyll- $a$ concentra- tions were small (median $8.2 \mu \mathrm{g} / \mathrm{L}$ ). Twelve pesticide compounds were detected. Atrazine and its breakdown product, 2-chloro-4-isopropylamino-6-amino-s-triazine (CIAT), were the most commonly detected pesticides; some atrazine concentrations were larger than the USEPA MCL of $3.0 \mu \mathrm{g} / \mathrm{L}$.

Summary statistics for nitrogen compounds, phosphorus, suspended sediment, organic carbon, turbidity, chlorophyll- $a$, and selected pesticides at all three sites combined are listed in table 4 .

\section{Nitrogen}

Total nitrogen consists of ammonia plus organic nitrogen and nitrite plus nitrate nitrogen (fig. 4). In Lake Houston, the average contribution of ammonia plus organic nitrogen to total nitrogen was about 69 percent. The contribution from nitrite plus nitrate nitrogen was about 31 percent.

The spatial variability of nitrogen concentrations correlated with inflows from urban areas. Median total nitrogen concentrations in samples from Lake Houston (fig. 5) were largest at site FC, smallest at site EC, and intermediate in value at site AC. Total nitrogen concentrations for all samples ranged from 0.33 to $3.1 \mathrm{mg} / \mathrm{L}$. The relative importance of nitrite plus nitrate and ammonia plus organic nitrogen varied at the sites (fig. 4). At site FC, variability in total nitrogen reflected changes in concentrations of nitrite plus nitrate nitrogen, which ranged from less than 0.06 to $2.70 \mathrm{mg} / \mathrm{L}$. Ammonia plus organic nitrogen contributed about 60 percent of the total nitrogen. At site EC, ammonia plus organic nitrogen was the primary constituent, ranging from 0.25 to $0.55 \mathrm{mg} / \mathrm{L}$ (fig. 5); nitrite plus nitrate nitrogen contributed about 25 percent of the nitrogen. At site AC, total nitrogen concentrations were intermediate to those at lake inflow sites EC and FC, with ammonia plus organic nitrogen contributing about 63 percent to total nitrogen at site AC.

Concentrations of nitrogen varied during the year. The overall median concentration of nitrite plus nitrate nitrogen in Lake Houston decreased from $0.52 \mathrm{mg} / \mathrm{L}$ in winter to less than $0.06 \mathrm{mg} / \mathrm{L}$ in late summer. This pattern of decreasing concentrations occurred at all sites.

\section{Phosphorus, Suspended Sediment, and Organic Carbon}

Total phosphorus includes dissolved forms as well as phosphorus that is attached to sediment particles and in living organisms like algae and bacteria. The part of total phosphorus that is readily available in the water as a nutrient to algae is the dissolved form. Dissolved phosphorus comprises orthophosphate (fig. 6) and organic phosphorus. Between about 58 and 97 percent of the dissolved phosphorus in Lake Houston samples was orthophosphate phosphorus. Dissolved phosphorus concentrations for all samples (table 4) ranged from less than 0.004 to $0.620 \mathrm{mg} / \mathrm{L}$, with a median concentration of 0.104 $\mathrm{mg} / \mathrm{L}$. More than 97 percent of the samples analyzed for dissolved phosphorus had a concentration larger than $0.025 \mathrm{mg} / \mathrm{L}$. 
(a) TOTAL NITROGEN

SITE AC

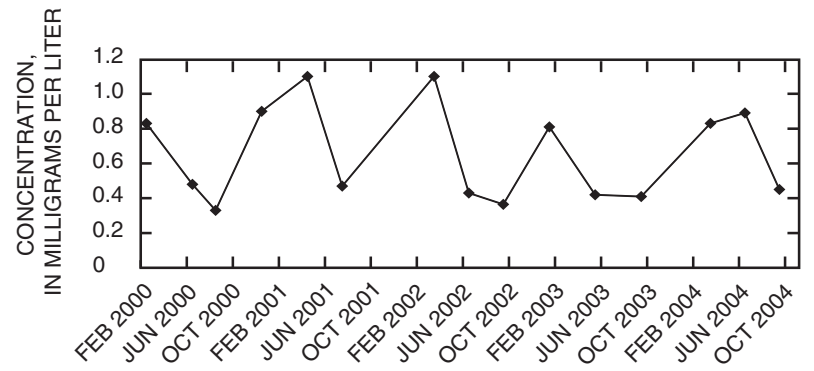

DATE
SITE EC

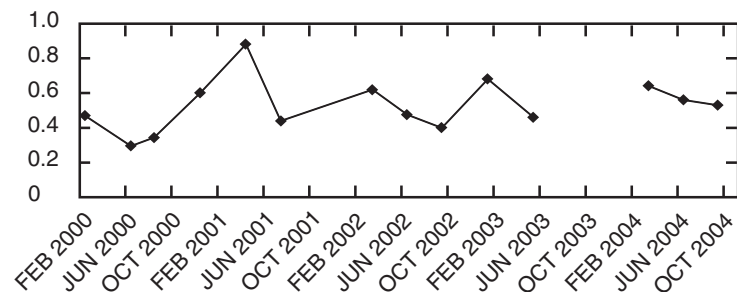

DATE

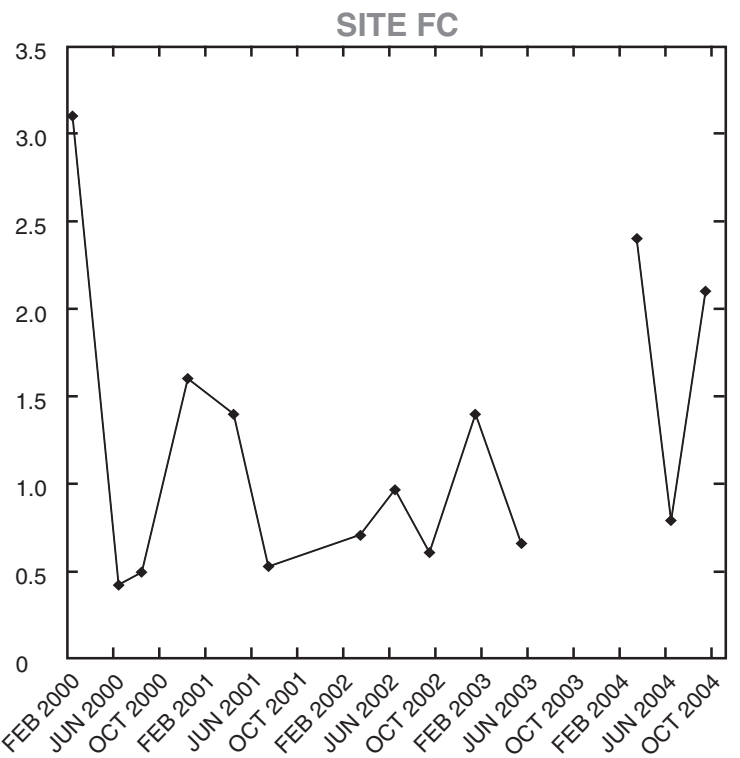

DATE

(b) NITRITE PLUS NITRATE NITROGEN AND AMMONIA PLUS ORGANIC NITROGEN

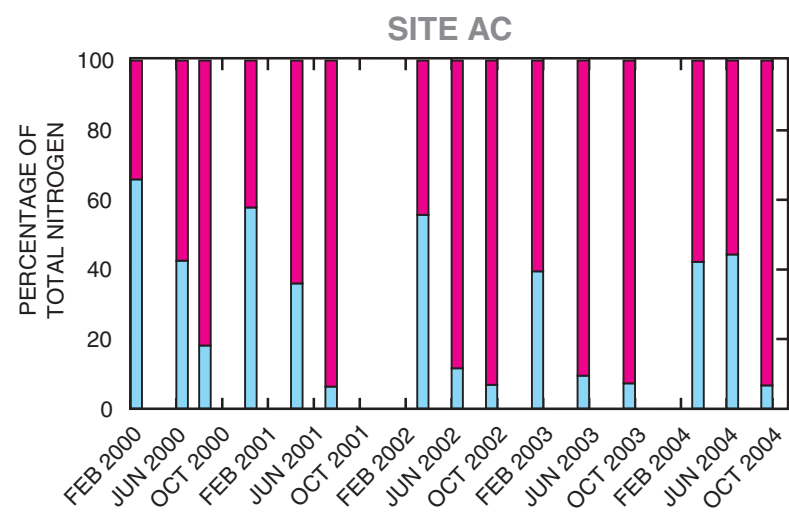

DATE

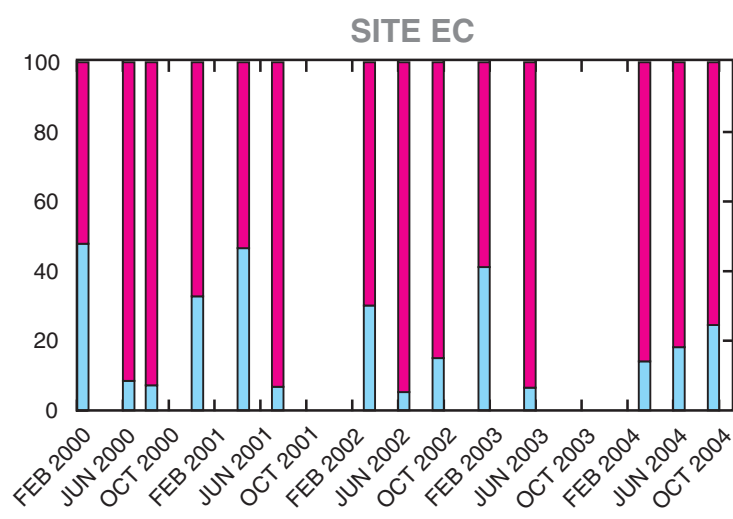

DATE

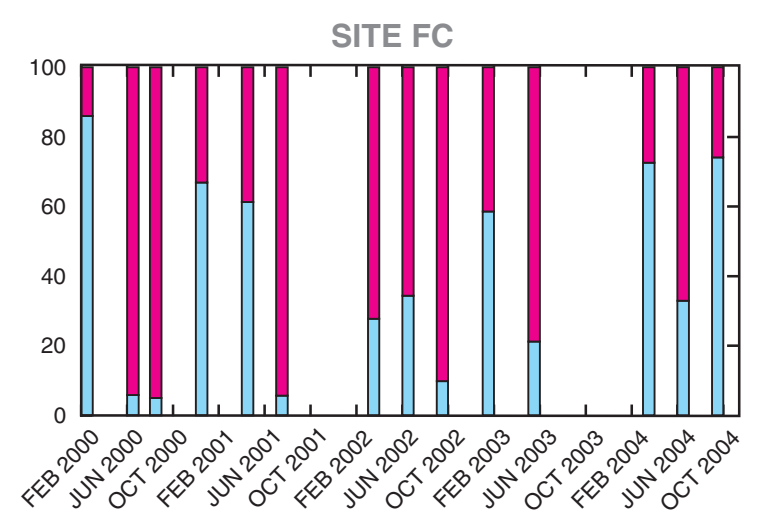

DATE

Figure 4. (a) Total nitrogen and (b) relative contributions to total nitrogen of nitrite plus nitrate nitrogen (cyan) and ammonia plus organic nitrogen (magenta) at three sites in Lake Houston near Houston, Texas, February 2000-September 2004. 
(a) TOTAL NITROGEN

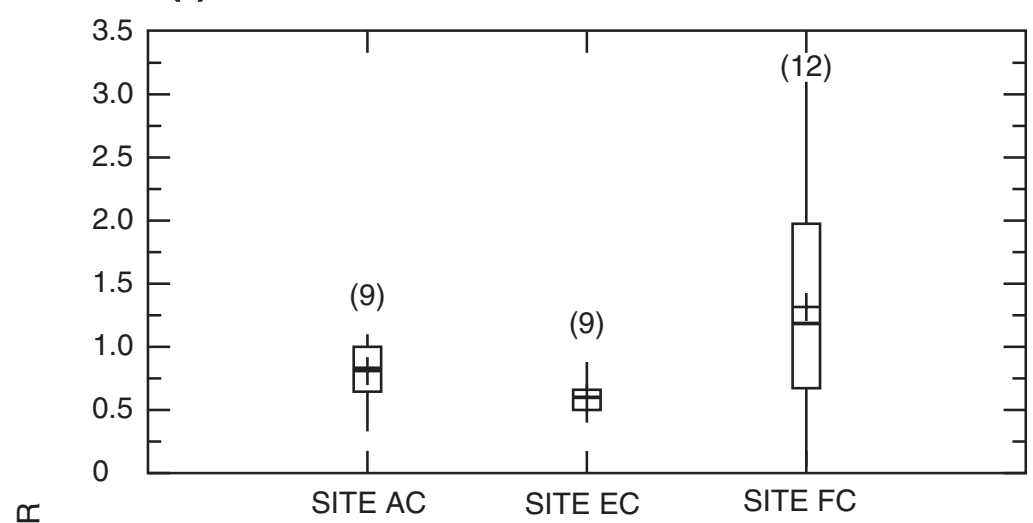

(b) NITRITE PLUS NITRATE NITROGEN

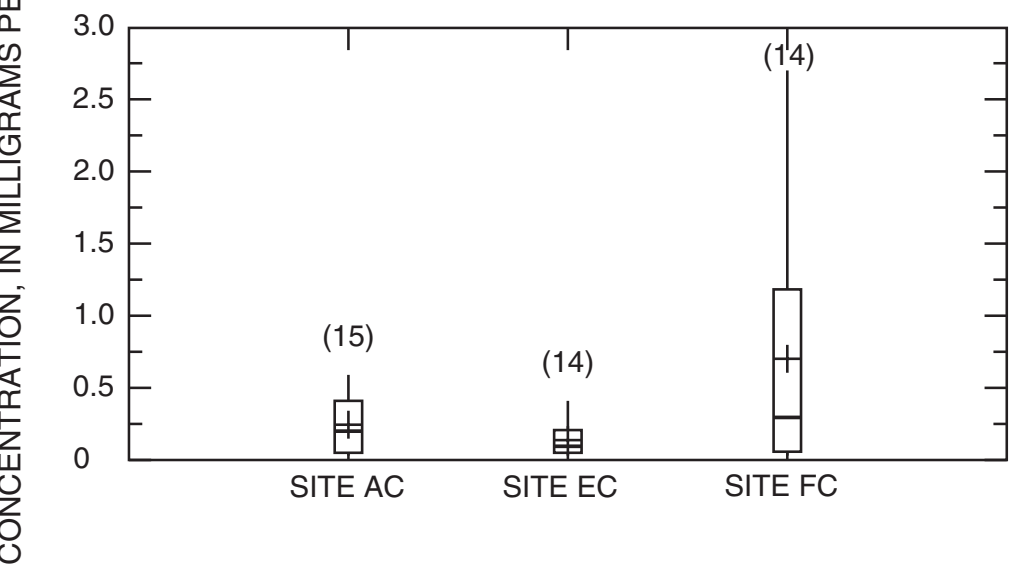

(c) AMMONIA PLUS ORGANIC NITROGEN

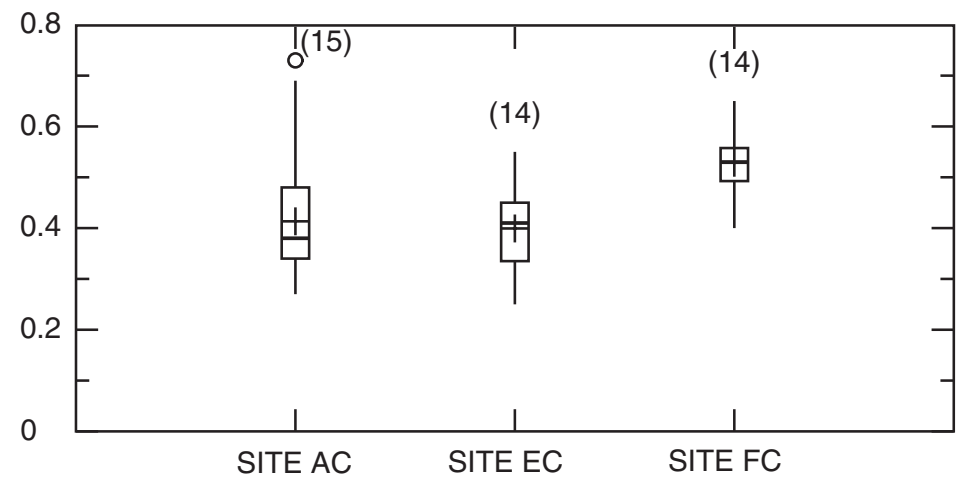

\section{EXPLANATION}

(14) Sample size

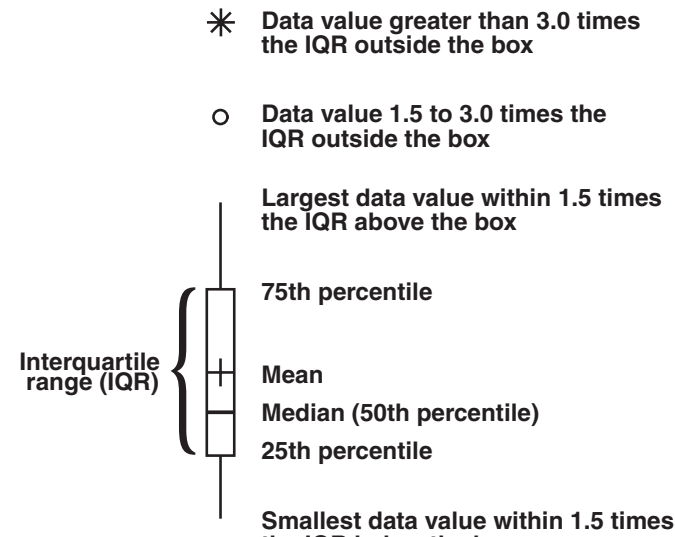

the IQR below the box

Figure 5. Distribution of (a) total nitrogen, (b) nitrite plus nitrate nitrogen, and (c) ammonia plus organic nitrogen at three sites in Lake Houston near Houston, Texas, February 2000-September 2004.

Dissolved phosphorus concentrations varied among sampling sites (fig. 7), similar to the variation of nitrite plus nitrate nitrogen. Dissolved phosphorus concentrations at sites EC and AC were generally less than $0.15 \mathrm{mg} / \mathrm{L}$. Dissolved phosphorus concentrations at site $\mathrm{FC}$ were consistently larger than those at other sites; the median concentration was about 4.5 times larger than the median at site EC and about 3.3 times larger than the median at site AC. Comparison of the sites using the Wilcoxon rank-sum test (three tests: EC to FC, FC to $\mathrm{AC}, \mathrm{AC}$ to $\mathrm{EC}$ ) demonstrated that dissolved phosphorus concentrations at site $\mathrm{FC}$ were significantly different (larger) $(\mathrm{p}<.001)$ than those at either site $\mathrm{AC}$ or site EC. Concentrations at site $\mathrm{AC}$ also were significantly different (larger) than those at site EC $(\mathrm{p}=.01)$. When the data were grouped by season and compared between 


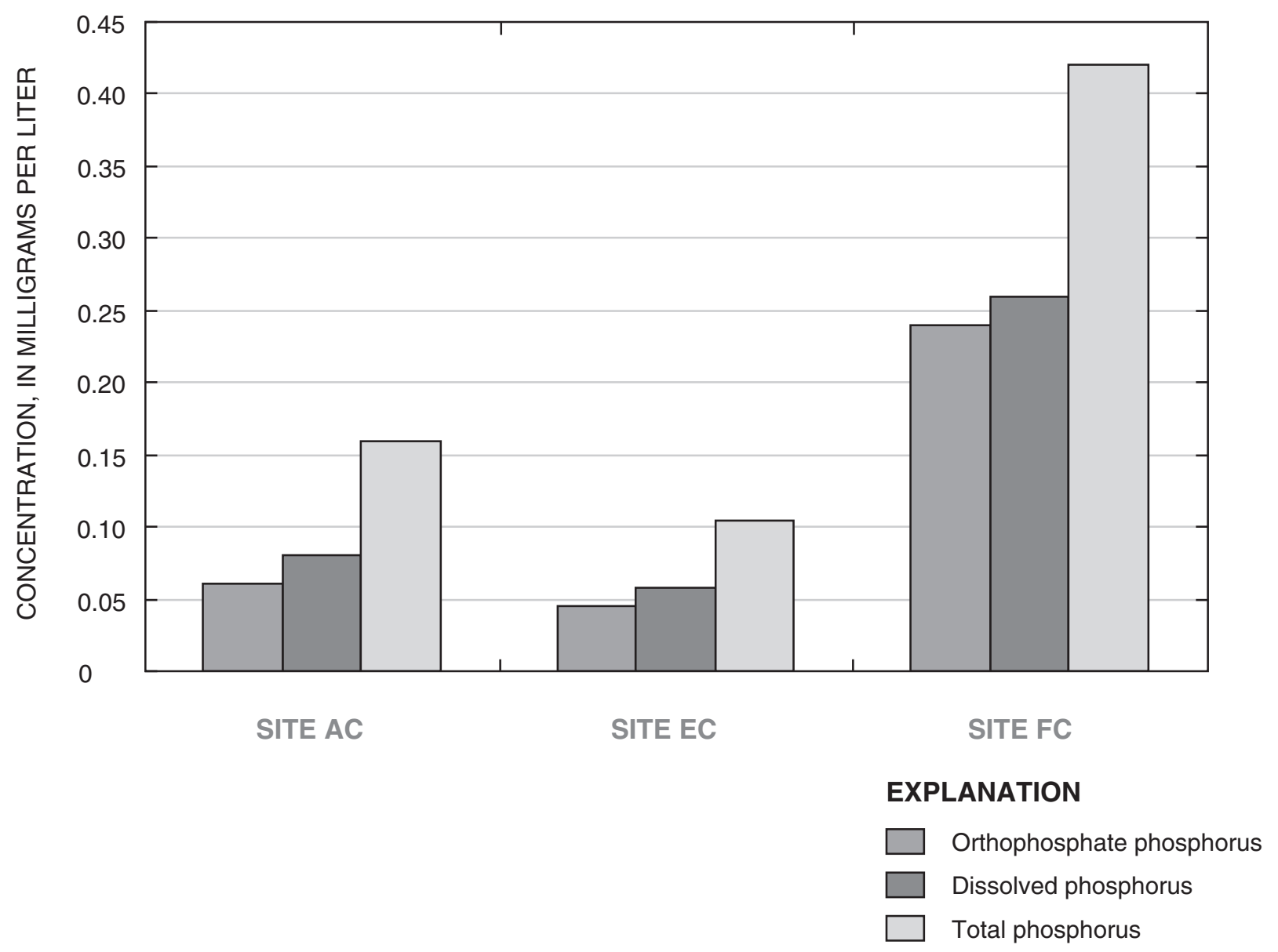

Figure 6. Median concentrations of orthophosphate phosphorus, dissolved phosphorus, and total phosphorus at three sites in Lake Houston near Houston, Texas, February 2000-September 2004.

sites, only winter concentrations at site $\mathrm{AC}$ were significantly different (larger) $(\mathrm{p}=.04)$ than winter concentrations at site EC. A caution, however: The sizes of the seasonal sample groups that were compared in these (and some other) rank-sum tests were small (fewer than 10 samples each). Statistical tests on groups with few data per group might lack the power to detect differences, if they exist, as the power of statistical tests to detect differences increases as sample size increases (Helsel and Hirsch, 1992, p. 107).

The amount of suspended sediment in Lake Houston is a product of several factors that include the intensity and volume of precipitation, discharge from inflowing streams, and intensity and direction of the wind. Sediment concentrations at site FC were about twice those measured at site EC (fig. 7) and three times larger than concentrations at site $\mathrm{AC}$ near the dam.

Median suspended-sediment concentrations were $43 \mathrm{mg} / \mathrm{L}$ at site FC; $23 \mathrm{mg} / \mathrm{L}$ at site EC; and $12 \mathrm{mg} / \mathrm{L}$ at site $\mathrm{AC}$, the farthest from sediment sources.

The maximum suspended-sediment concentrations at all lake sites (appendixes 1-3) were collected in April 2001. During that month, daily peak wind speeds averaged about 25 miles per hour; immediately preceding sample collection, the wind direction changed from the southeast to north and northeast (National Oceanic and Atmospheric Administration, 2005), parallel to the long axis of the lake. Strong winds with a northsouth orientation make the water of Lake Houston very turbulent, which because of the shallowness of the lake, cause resuspension and mixing of bottom sediments. Sediment concentrations in samples collected during this time ranged from 709 to $767 \mathrm{mg} / \mathrm{L}$, between 17 and 59 times larger than the median concentrations at the sites.

Dissolved organic carbon concentrations were consistent throughout the lake; overall the median concentration was $7.7 \mathrm{mg} / \mathrm{L}$ (table 4). The largest concentration in all samples was $14.8 \mathrm{mg} / \mathrm{L}$ at site EC; the smallest concentration, also at site EC, was $3.7 \mathrm{mg} / \mathrm{L}$ (fig. 7). The largest median dissolved organic carbon concentration was at site $\mathrm{AC}(8.4 \mathrm{mg} / \mathrm{L})$.

\section{Transparency, Turbidity, and Chlorophyll-a}

Secchi disk transparency and turbidity are two principal indicators of water clarity. Secchi disk transparency was less 
Table 4. Statistical summary of nitrogen compounds, phosphorus, suspended sediment, organic carbon, chlorophyll-a, and selected pesticides for sites AC, EC, and FC combined, Lake Houston near Houston, Texas, February 2000-September 2004.

[ $\geq$, equal to or greater than; mg/L, milligrams per liter; --, not applicable; <, less than; m, meters; NTU, nephelometric turbidity units; $\mu \mathrm{g} / \mathrm{L}$, micrograms per liter; E, estimated]

\begin{tabular}{|c|c|c|c|c|c|c|c|c|}
\hline Constituent & $\begin{array}{c}\text { Number } \\
\text { of } \\
\text { samples }\end{array}$ & $\begin{array}{c}\text { Minimum } \\
\text { reporting } \\
\text { level }\end{array}$ & $\begin{array}{l}\text { Number of } \\
\text { detections } \\
\geq \text { reporting } \\
\quad \text { level }\end{array}$ & \multicolumn{5}{|c|}{ Concentration } \\
\hline Ammonia + organic nitrogen, dissolved $(\mathrm{mg} / \mathrm{L})$ & 43 & 0.10 & 43 & 0.25 & 0.38 & 0.44 & 0.52 & 0.73 \\
\hline Ammonia + organic nitrogen, total $(\mathrm{mg} / \mathrm{L})$ & 45 & .10 & 45 & .47 & .69 & .76 & .98 & 1.50 \\
\hline Nitrite + nitrate nitrogen, dissolved (mg/L) & 43 & .06 & 29 & $<.06$ & $<.06$ & .19 & .41 & 2.70 \\
\hline Nitrite, dissolved (mg/L) & 43 & .010 & 10 & $<.010$ & $<.010$ & $<.010$ & .011 & .043 \\
\hline Nitrogen $^{2}$, total $(\mathrm{mg} / \mathrm{L})$ & 29 & -- & -- & .33 & .60 & .81 & 1.1 & 3.1 \\
\hline Orthophosphate phosphorus, dissolved (mg/L) & 43 & .018 & 40 & $<.018$ & .050 & .090 & .160 & .570 \\
\hline Transparency, Secchi depth (m) & 45 & .01 & 45 & .10 & .24 & .30 & .49 & 1.15 \\
\hline Turbidity (NTU) & 35 & 1 & 35 & 7 & 22 & 36 & 58 & 270 \\
\hline Suspended sediment (mg/L) & 39 & 1 & 39 & 6 & 17 & 27 & 44 & 767 \\
\hline Organic carbon, dissolved (mg/L) & 45 & .33 & 45 & 3.7 & 6.6 & 7.7 & 9.4 & 14.8 \\
\hline Organic carbon, total (mg/L) & 45 & .40 & 45 & 6.4 & 9.6 & 11.4 & 13.0 & 15.5 \\
\hline Chlorophyll- $a$ phytoplankton ( $\mu \mathrm{g} / \mathrm{L})$ & 45 & .1 & 44 & $<.1$ & 3.0 & 8.2 & 21.0 & 53.9 \\
\hline Atrazine, dissolved $(\mu \mathrm{g} / \mathrm{L})$ & 45 & .007 & 45 & .043 & .182 & .454 & .835 & 4.450 \\
\hline $\begin{array}{l}\text { 2-Chloro-4-isopropylamino-6-amino-s-triazine } \\
\text { (CIAT), dissolved }(\mu \mathrm{g} / \mathrm{L})\end{array}$ & 45 & .006 & 43 & $<.006$ & E.011 & E.029 & E.069 & E. 152 \\
\hline
\end{tabular}

than 1 meter ( 3.3 feet) in about 98 percent of measurements in Lake Houston; in 84 percent of the measurements, transparency was less than or equal to 0.5 meter ( 1.6 feet). Transparency was the least near lake inflow sites EC and FC and greatest near the dam at site AC (fig. 8). Turbidity, an optical measure of light scattering, is inversely related to transparency depth. Overall, turbidity ranged from 7 to 270 NTUs (fig. 8, table 4). Median turbidity for all samples was 36 NTUs (table 4); however, the range of values was large at sites $\mathrm{AC}$ and $\mathrm{FC}$. The maximum turbidity at site $\mathrm{AC}$ was about 10 times greater than the median at that site.

Concentrations of chlorophyll- $a$ were used as an indicator of the amount (biomass) of phytoplankton. Chlorophyll- $a$ concentrations decreased from the lake inflows to the dam; the largest concentrations were at site FC, which had a median of $16.4 \mu \mathrm{g} / \mathrm{L}$ (fig. 8). Median chlorophyll- $a$ concentration at site EC was $9.2 \mu \mathrm{g} / \mathrm{L}$. The smallest chlorophyll- $a$ concentrations were measured in samples at site AC, which had a median of $6.8 \mu \mathrm{g} / \mathrm{L}$. Overall concentrations in Lake Houston ranged from less than 0.1 to $53.9 \mu \mathrm{g} / \mathrm{L}$ with a median concentration of 8.2 $\mu \mathrm{g} / \mathrm{L}$ (table 4). From Wilcoxon rank-sum tests between sites, chlorophyll- $a$ concentrations at site FC were significantly different (larger) than those at sites AC $(\mathrm{p}<.001)$ and EC $(\mathrm{p}=.009)$. Concentrations at site EC were significantly different (larger) than those at site AC ( $\mathrm{p}=.029)$. Testing the data grouped by season between sites indicated that, for winter and summer, concentrations were not significantly different; for spring, however, concentrations at site FC were significantly 
(a) DISSOLVED PHOSPHORUS

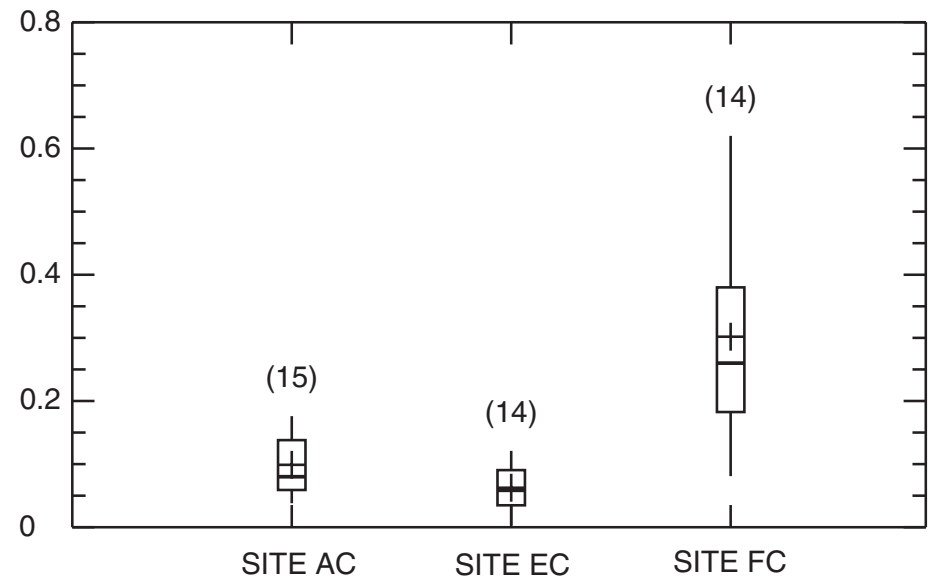

(b) SUSPENDED SEDIMENT

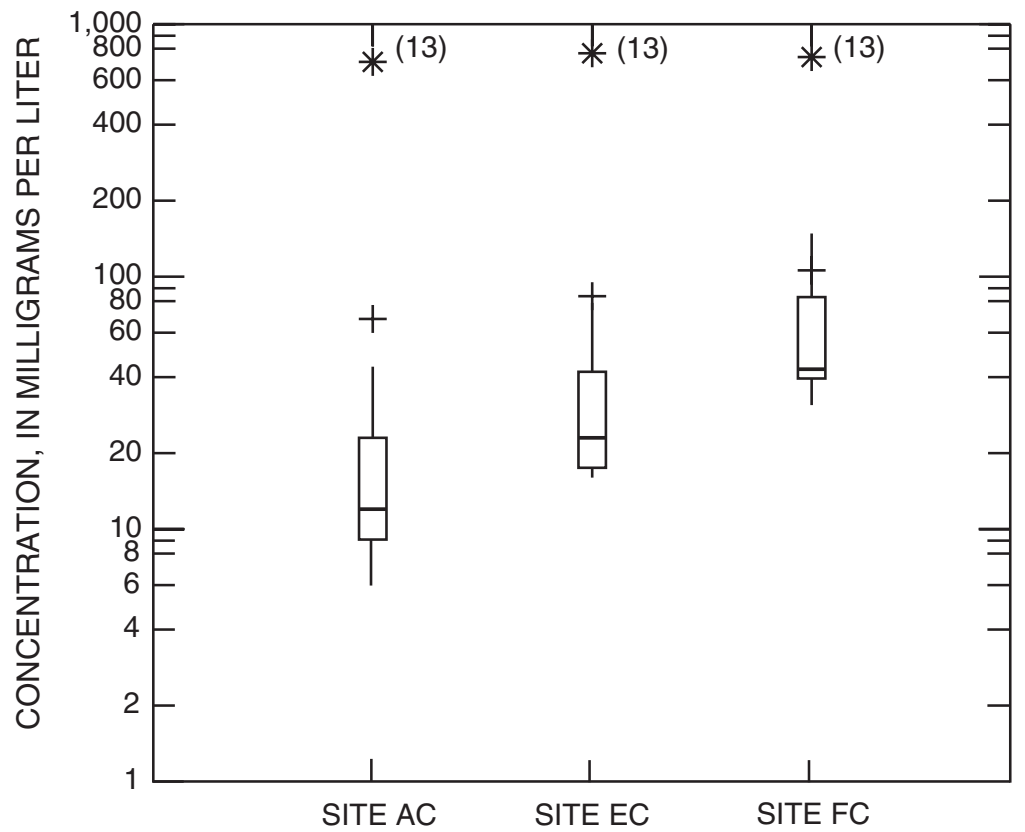

(c) DISSOLVED ORGANIC CARBON

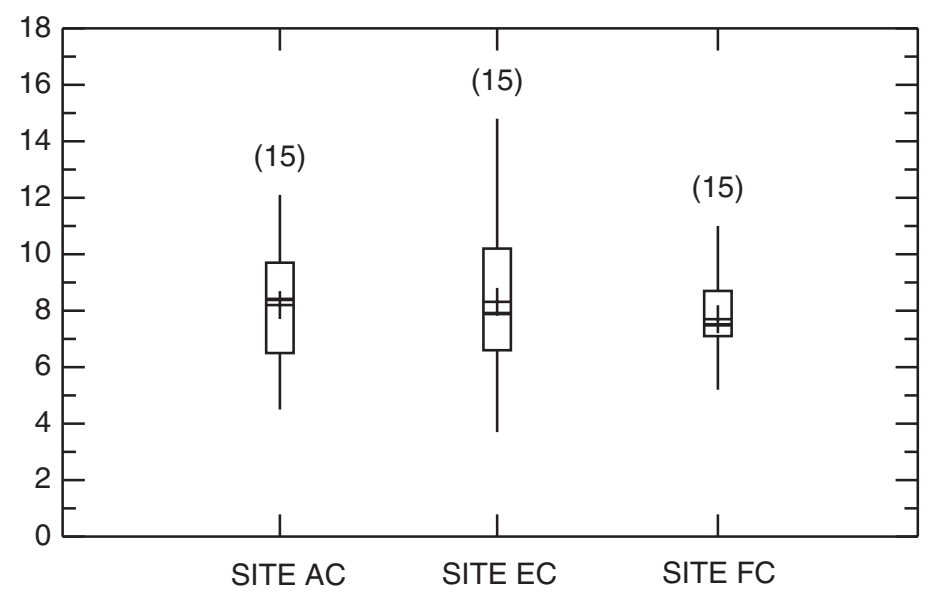

\section{EXPLANATION}

(14) Sample size

Data value greater than 3.0 times the IQR outside the box

○ Data value 1.5 to 3.0 times the IQR outside the box

Largest data value within 1.5 times the IQR above the box

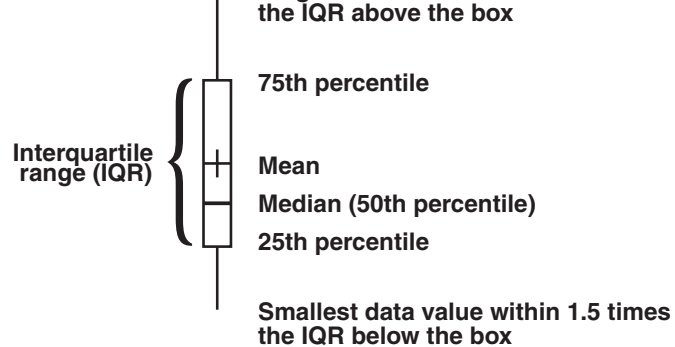

Figure 7. Distribution of (a) dissolved phosphorus, (b) suspended sediment, and (c) dissolved organic carbon at three sites in Lake Houston near Houston, Texas, February 2000-September 2004. 
(a) TRANSPARENCY
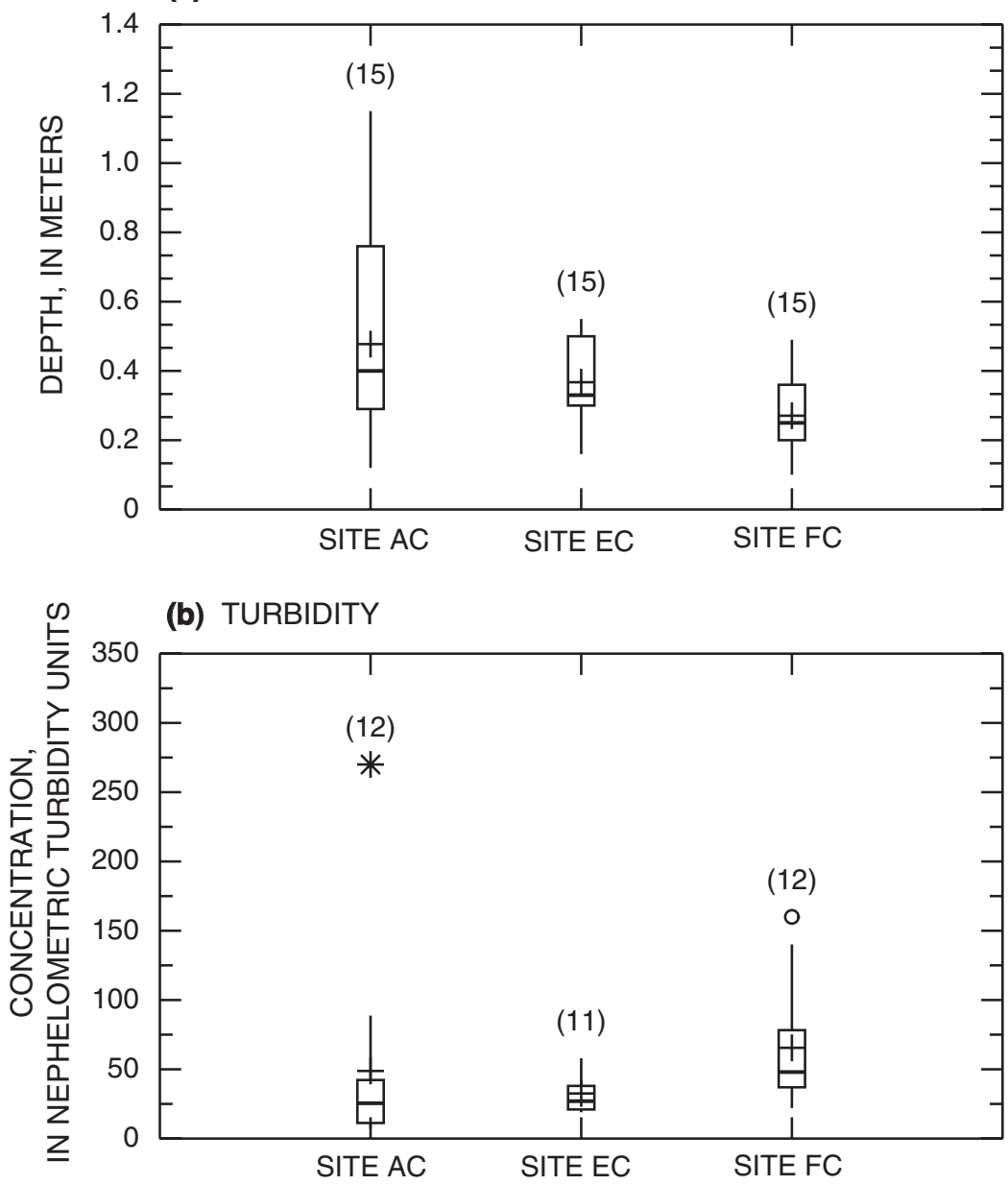

\section{EXPLANATION}

(11) Sample size

Data value greater than 3.0 times the IQR outside the box

- Data value 1.5 to 3.0 times the IQR outside the box

Largest data value within 1.5 times the IQR above the box

75th percentile

(c) CHLOROPHYLL-a

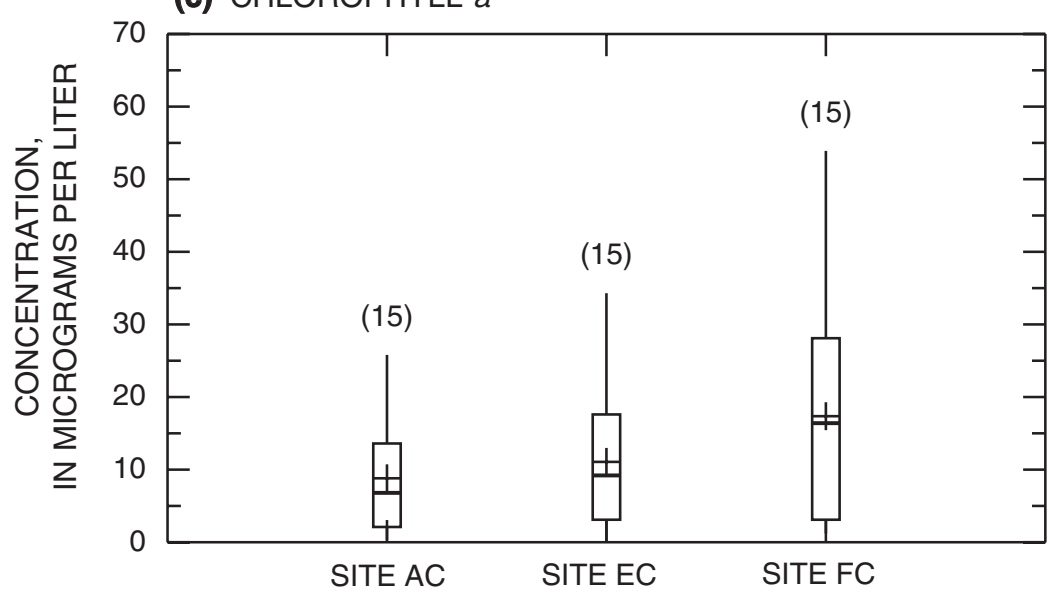

Smallest data value within 1.5 times the IQR below the box

Figure 8. Distribution of (a) transparency, (b) turbidity, and (c) chlorophyll-a at three sites in Lake Houston near Houston, Texas, February 2000-September 2004.

different (larger) than those at sites EC $(\mathrm{p}=.007)$ and $\mathrm{AC}$ $(\mathrm{p}=.002)$.

In Lake Houston, concentrations of phosphorus, turbidity, and chlorophyll- $a$ were largest at the lake inflow sites and decreased downstream to the dam, similar to a pattern of productivity described by Thornton and others (1990). Lee and Rast (1997) reported that nutrients were not the limiting factor for algal production in Lake Houston; light might be the 
Table 5. Summary of pesticide detections at sampling sites in Lake Houston, Cypress Creek, and East Fork San Jacinto River, near Houston, Texas, 2000-2004.

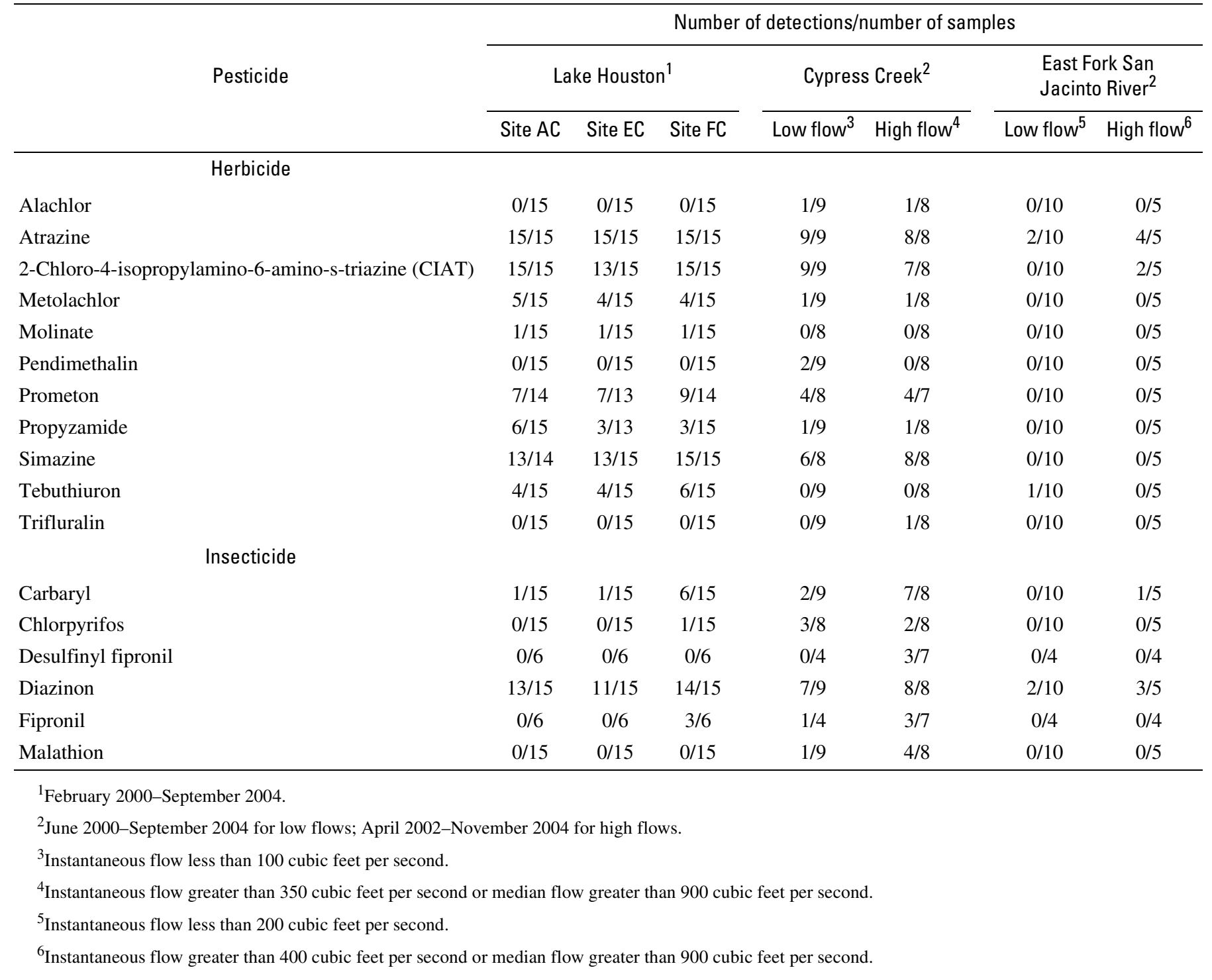

limiting factor. Periods of high turbidity caused by mixing of lake waters by wind reduces the amount of light penetrating the water column, thereby limiting algal production.

\section{Pesticides}

Twelve pesticide compounds (eight herbicides and four insecticides) were detected in 45 water samples collected at Lake Houston (15 at each site) (table 5). The most commonly detected herbicide compounds were atrazine (45 detections), CIAT, a breakdown product of atrazine (43 detections), and simazine (41 detections). The most commonly detected insecticide was diazinon (38 detections).

Of the median combined atrazine concentration (atrazine plus CIAT), 93 percent was the parent compound and 7 percent was the breakdown product. Combined concentrations ranged from 0.047 to $4.526 \mu \mathrm{g} / \mathrm{L}$. The median combined concentration in all samples was $0.517 \mu \mathrm{g} / \mathrm{L}$. The USEPA MCL for atrazine of $3.0 \mu \mathrm{g} / \mathrm{L}$ was exceeded in two samples, both from site FC (fig. 9). Concentrations of atrazine at site FC were consistently larger than those at other lake sites. Atrazine concentrations were smallest at site EC. The atrazine concentrations at site AC were intermediate, possibly reflecting mixing from all inflows to the lake and local runoff.

Diazinon and simazine were detected in Lake Houston in much smaller concentrations than those of atrazine (fig. 9).

Small concentrations of these pesticides in Lake Houston might be related to a combination of (1) low use in the drainage basin; (2) lack of stability of the compound in the environment; and, (3) degradation of the parent compound to breakdown products that were not determined. The highest percentage of detections and largest concentrations of both compounds were at site FC. 

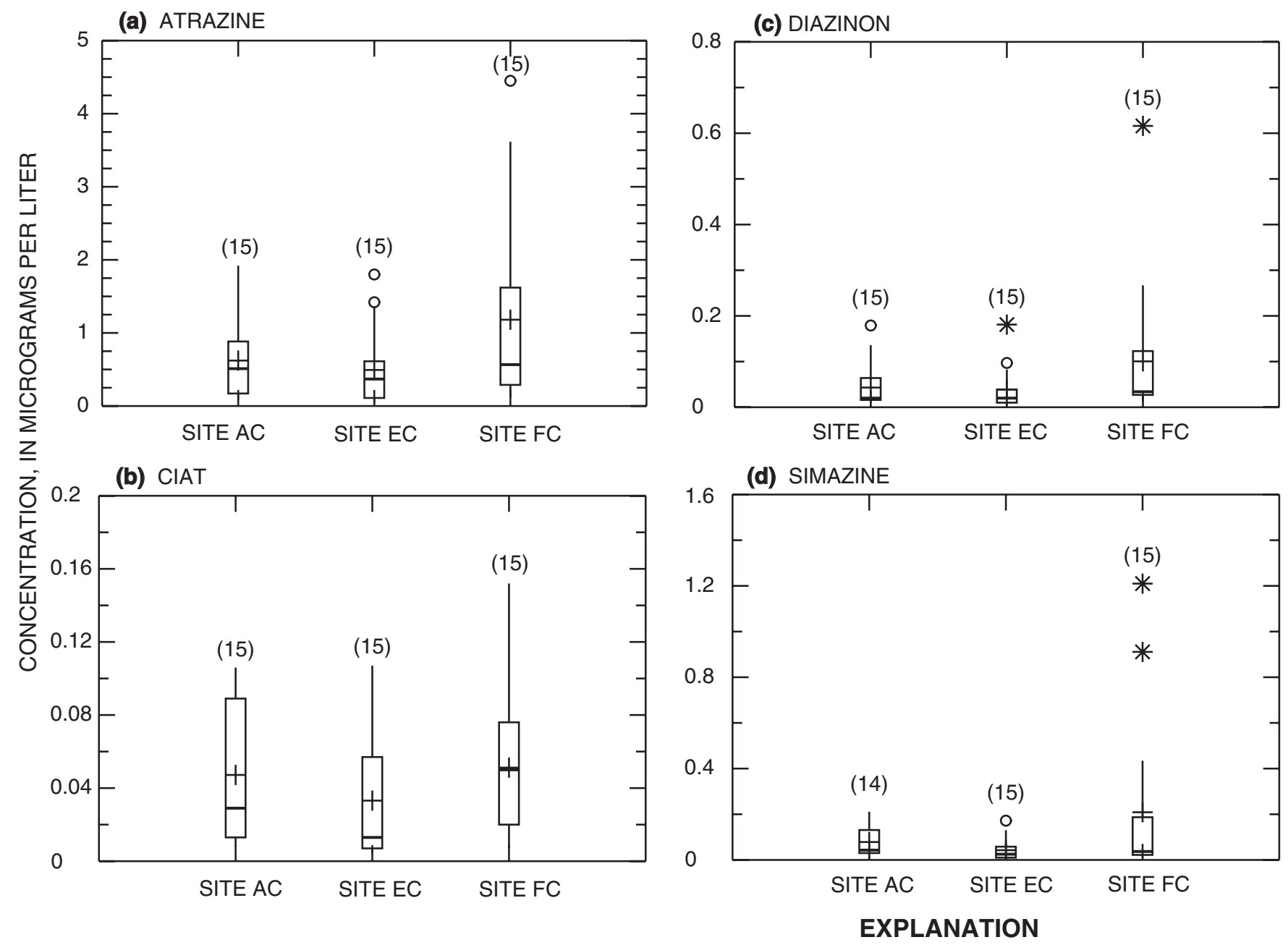

(15) Sample size

* Data value greater than 3.0 times the IQR outside the box

○ Data value 1.5 to 3.0 times the IQR outside the box

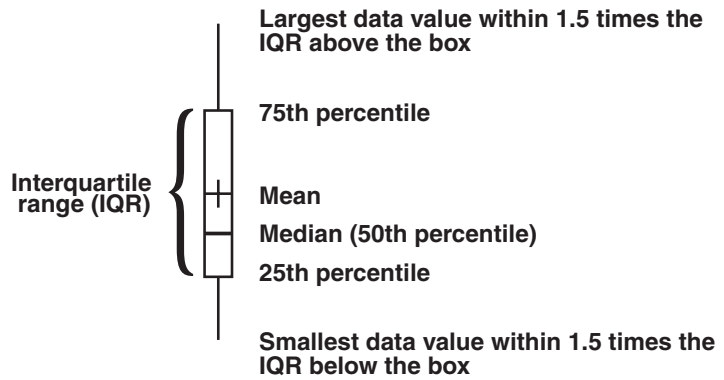

Figure 9. Distribution of (a) atrazine, (b) 2-chloro-4-isopropylamino-6-amino-s-triazine (CIAT), (c) diazinon, and (d) simazine at three sites in Lake Houston near Houston, Texas, February 2000-September 2004.

\section{Tributary Inflows, 2000-2004}

Water-quality samples were collected at Cypress Creek and East Fork San Jacinto River during low flows and during high flows associated with storms. Low flows in Cypress Creek consisted of instantaneous discharges less than 100 cubic feet per second; high flows consisted of instantaneous discharges greater than 350 cubic feet per second or median discharges 
greater than 900 cubic feet per second. In East Fork San Jacinto River, low flows were instantaneous discharges less than 200 cubic feet per second; high flows consisted of instantaneous discharges greater than 400 cubic feet per second or median discharges greater than 900 cubic feet per second. Because samples during high flows were not collected at any time until April 2002, data adequately represent the range of flows from these two streams only during 2002-04 (fig. 10). Statistical results of field measurements, physical properties, and constituents for each data-collection site at low and high flows are shown in appendixes 4-7.

\section{Constituent Concentrations}

During low-flow conditions in Cypress Creek, total nitrogen primarily was nitrite plus nitrate nitrogen (fig. 11), which contributed 86 percent of the total nitrogen; nitrate nitrogen was 85 percent of the dissolved nitrogen and nitrite nitrogen was 1 percent. The remainder consisted of organic nitrogen (12 percent) and ammonia nitrogen ( 2 percent). Nitrate, nitrite, and organic nitrogen were detected in all samples. During high flows in Cypress Creek, the largest contributor to total nitrogen was organic nitrogen, which accounted for about 66 percent. Nitrate (28 percent), ammonia ( 5 percent), and nitrite ( 1 percent) nitrogen contributed the remaining dissolved nitrogen. Concentrations of all nitrogen compounds in East Fork San Jacinto River samples were small when compared to those in Cypress Creek samples. During low flows, organic nitrogen was detected in all samples at East Fork San Jacinto River and contributed about 60 percent of the total nitrogen. The remaining nitrogen was in the form of nitrite plus nitrate (fig. 11), which had a maximum concentration of $0.23 \mathrm{mg} / \mathrm{L}$. No samples had detectable concentrations of ammonia or nitrite nitrogen. During high flows in East Fork San Jacinto River, organic nitrogen accounted for about 88 percent of the dissolved nitrogen concentration. Nitrite plus nitrate nitrogen was detected in two of five samples; no concentrations of ammonia nitrogen were detected.

During low flows in Cypress Creek, about 94 percent of the total phosphorus was dissolved. About 90 percent of the dissolved phosphorus was orthophosphate phosphorus (fig. 12). At high flows, about 50 percent of the total phosphorus was dissolved, and 85 percent of the dissolved phosphorus was orthophosphate phosphorus. In all samples at Cypress Creek, concentrations of dissolved phosphorus were larger than $0.05 \mathrm{mg} / \mathrm{L}$ (the USEPA-recommended limit for total phosphorus in a stream at the entry to a lake or reservoir) and ranged from 0.10 to $3.47 \mathrm{mg} / \mathrm{L}$. Dissolved phosphorus concentrations were about 10 times larger in Cypress Creek than in East Fork San Jacinto River. All samples at East Fork San Jacinto River had detectable dissolved phosphorus concentrations. Concentrations of dissolved phosphorus in East Fork San Jacinto River during low flows ranged from 0.009 to $0.034 \mathrm{mg} / \mathrm{L}$ and contributed about 31 percent of the total phosphorus (fig. 12). Dissolved phosphorus concentrations during high flows ranged from 0.025 to $0.038 \mathrm{mg} / \mathrm{L}$ and were about 25 percent of the total phosphorus.
Orthophosphate phosphorus was detected in 20 percent of all samples at East Fork San Jacinto River.

Suspended-sediment concentrations were positively correlated with streamflow. In Cypress Creek, suspended-sediment concentrations ranged from 13 to $65 \mathrm{mg} / \mathrm{L}$ during low flows, with a median concentration of $26 \mathrm{mg} / \mathrm{L}$ (fig. 13). Suspendedsediment concentrations in East Fork San Jacinto River were similar to those in Cypress Creek at low flows; however, at high flows concentrations differed appreciably. During high flows, suspended-sediment concentrations in Cypress Creek ranged from 118 to $957 \mathrm{mg} / \mathrm{L}$, with a median concentration of 308 $\mathrm{mg} / \mathrm{L}$, about twice the median concentration at East Fork San Jacinto River. These differences might result from differences in land cover and urbanization in the two watersheds. The primary land cover in the Cypress Creek watershed was grassland, and the primary land cover in the East Fork San Jacinto watershed was woodland (fig. 2). In addition, more than 10 percent of the Cypress Creek watershed was urbanized, which is more than twice the percentage of urbanized area of the East Fork San Jacinto River watershed.

Dissolved organic carbon was detected in all samples from both streams. In Cypress Creek, concentrations ranged from 5.1 to $7.0 \mathrm{mg} / \mathrm{L}$ during low-flow conditions and from 5.9 to 32.3 $\mathrm{mg} / \mathrm{L}$ during high flows associated with storms. Median concentrations during low flows and high flows were 6.5 and 13.4 mg/L, respectively (fig. 14). In East Fork San Jacinto River, dissolved organic carbon concentrations ranged from 2.5 to 10.0 $\mathrm{mg} / \mathrm{L}$ during low flows and from 9.6 to $15.9 \mathrm{mg} / \mathrm{L}$ during high flow (fig. 14).

At least one pesticide was detected in all samples collected at Cypress Creek (table 5). Of 15 pesticides detected, the most common was atrazine (100 percent), followed by CIAT (94.1 percent), diazinon (88.2 percent), and simazine (87.5 percent). The USEPA MCL of $3.0 \mu \mathrm{g} / \mathrm{L}$ was exceeded in three of 17 atrazine samples. Concentrations of all pesticides were larger during high flows associated with storm runoff than during low flows. Atrazine concentrations in Cypress Creek ranged from 0.065 to $8.83 \mu \mathrm{g} / \mathrm{L}$ in samples collected during low flows and from 0.282 to $21.3 \mu \mathrm{g} / \mathrm{L}$ in samples collected during high flows. Median concentrations during low and high flows were 0.612 and $1.09 \mu \mathrm{g} / \mathrm{L}$, respectively. CIAT was detected only in small concentrations and was about 3 percent of the concentrations of its parent compound, atrazine. Simazine was detected in six of eight samples from low flows at Cypress Creek and concentrations ranged from less than 0.005 to $0.242 \mu \mathrm{g} / \mathrm{L}$; during high flows, concentrations ranged from 0.009 to $3.27 \mu \mathrm{g} / \mathrm{L}$. Diazinon was the most frequently detected insecticide in Cypress Creek samples. During low flows, diazinon concentrations ranged from less than 0.010 to $1.08 \mu \mathrm{g} / \mathrm{L}$. During high flows, concentrations were slightly elevated, ranging from 0.024 to $1.17 \mu \mathrm{g} / \mathrm{L}$.

Five pesticides were detected in samples collected at East Fork San Jacinto River (table 5). Atrazine was the most commonly detected pesticide, present in six of 15 samples. Atrazine was detected more frequently, as well as at larger concentrations, in high-flow samples than in low-flow samples. Maximum concentrations were 0.019 and $0.233 \mu \mathrm{g} / \mathrm{L}$ during 
(a) 08069000 CYPRESS CREEK NEAR WESTFIELD, TEXAS

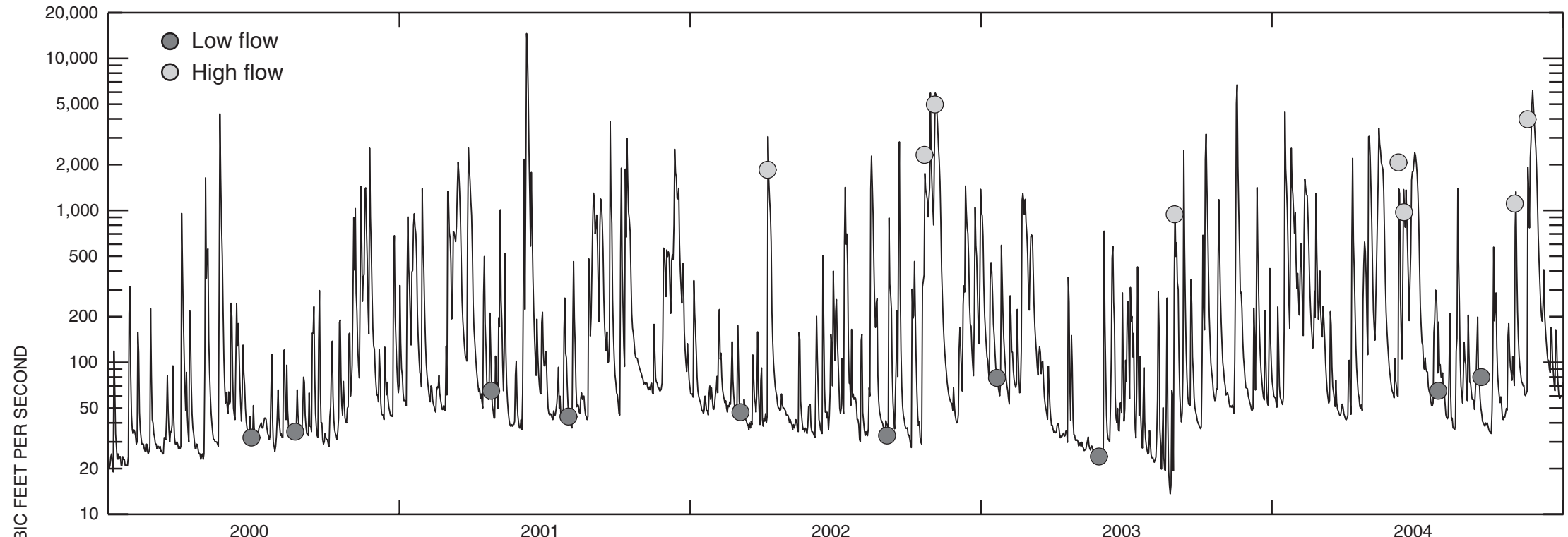

(b) 08070200 EAST FORK SAN JACINTO RIVER NEAR NEW CANEY, TEXAS

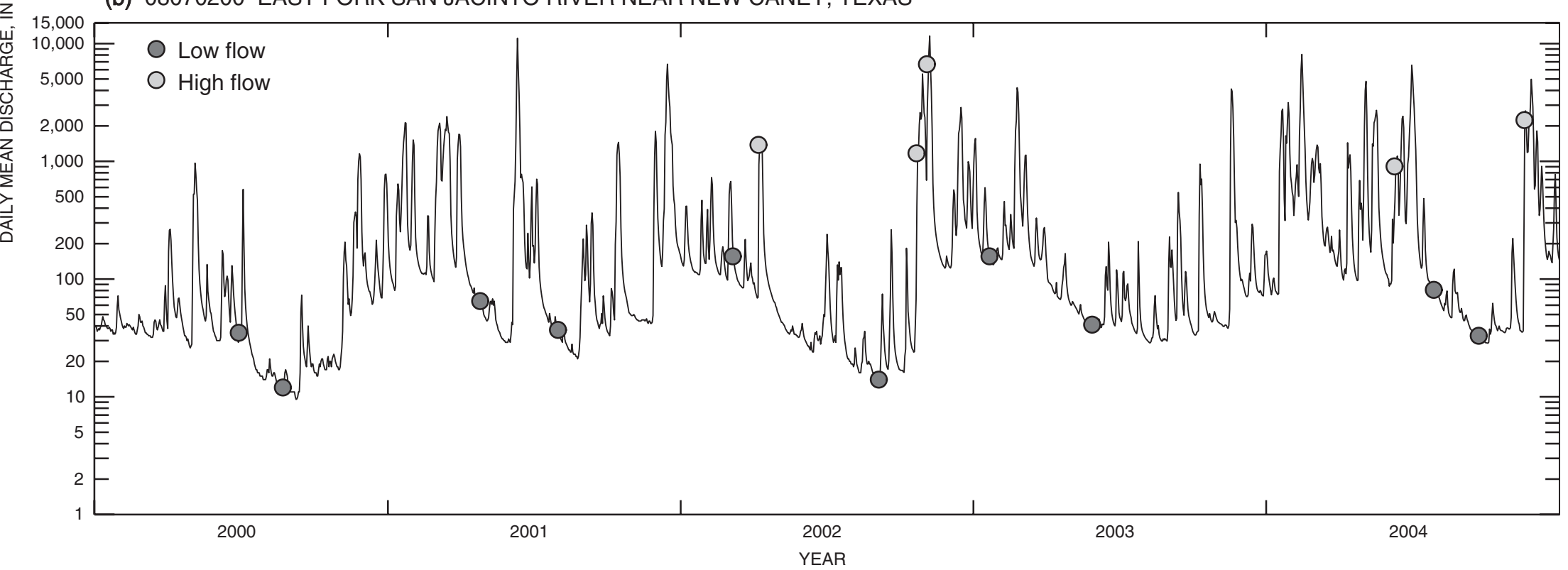

Figure 10. Hydrographs showing discharge, 2000-2004, and water-quality sampling during low flows (June 2000-September 2004) and high flows (April 2002-November 2004) at (a) Cypress Creek and (b) East Fork San Jacinto River near Houston, Texas. 
(a) CYPRESS CREEK

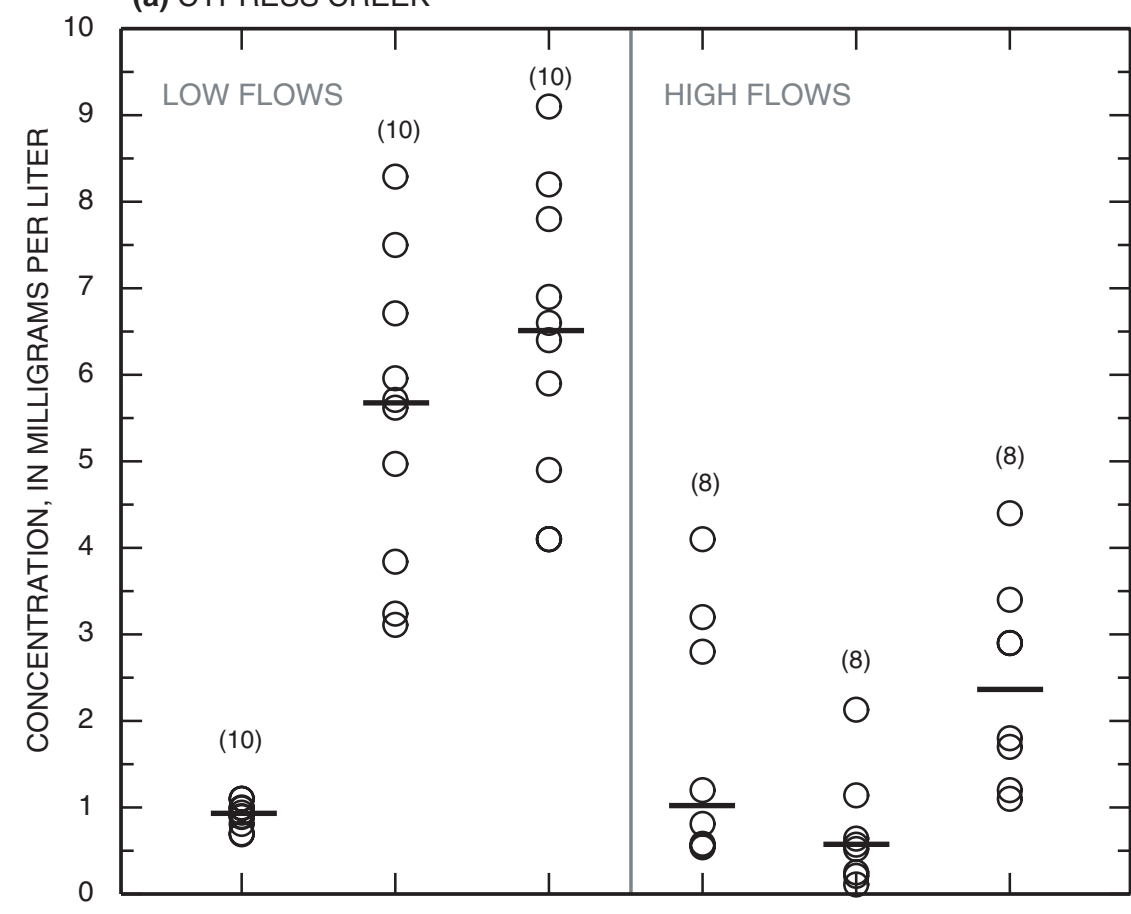

EXPLANATION

- Median

(10) Sample size

Flow

LOW FLOWS Instantaneous discharge less than 100 cubic feet per second

HIGH FLOWS Instantaneous discharge greater than 350 cubic feet per second or median discharge greater than 900 cubic feet per second

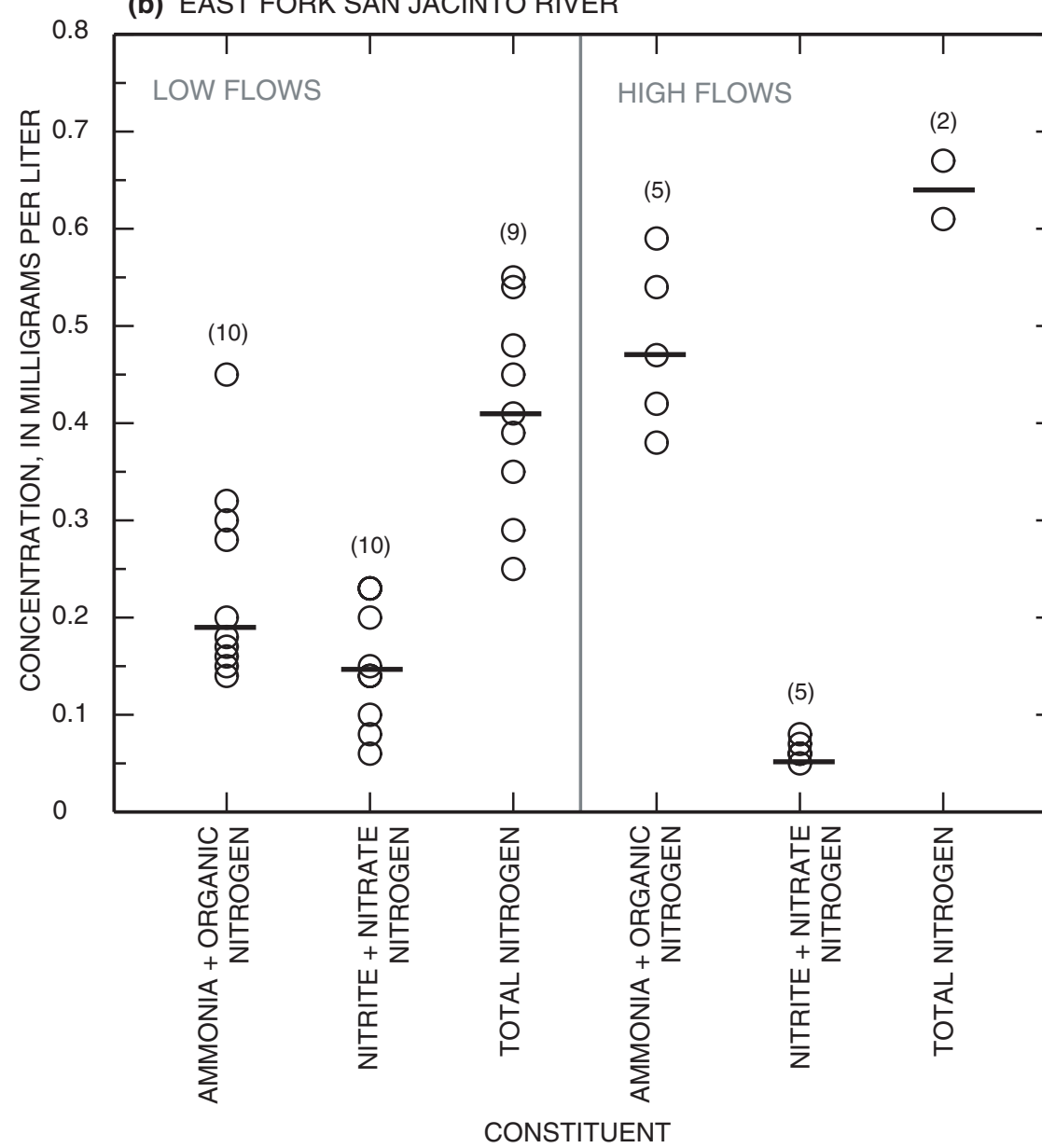

EXPLANATION

- Median

(5) Sample size

Flow

LOW FLOWS Instantaneous discharge less than 200 cubic feet per second

HIGH FLOWS Instantaneous discharge greater than 400 cubic feet per second or median discharge greater than 900 cubic feet per second

Figure 11. Distribution of nitrogen compounds at low flows (June 2000-September 2004) and high flows (April 2002-November 2004) at (a) Cypress Creek and (b) East Fork San Jacinto River near Houston, Texas. 
(a) CYPRESS CREEK
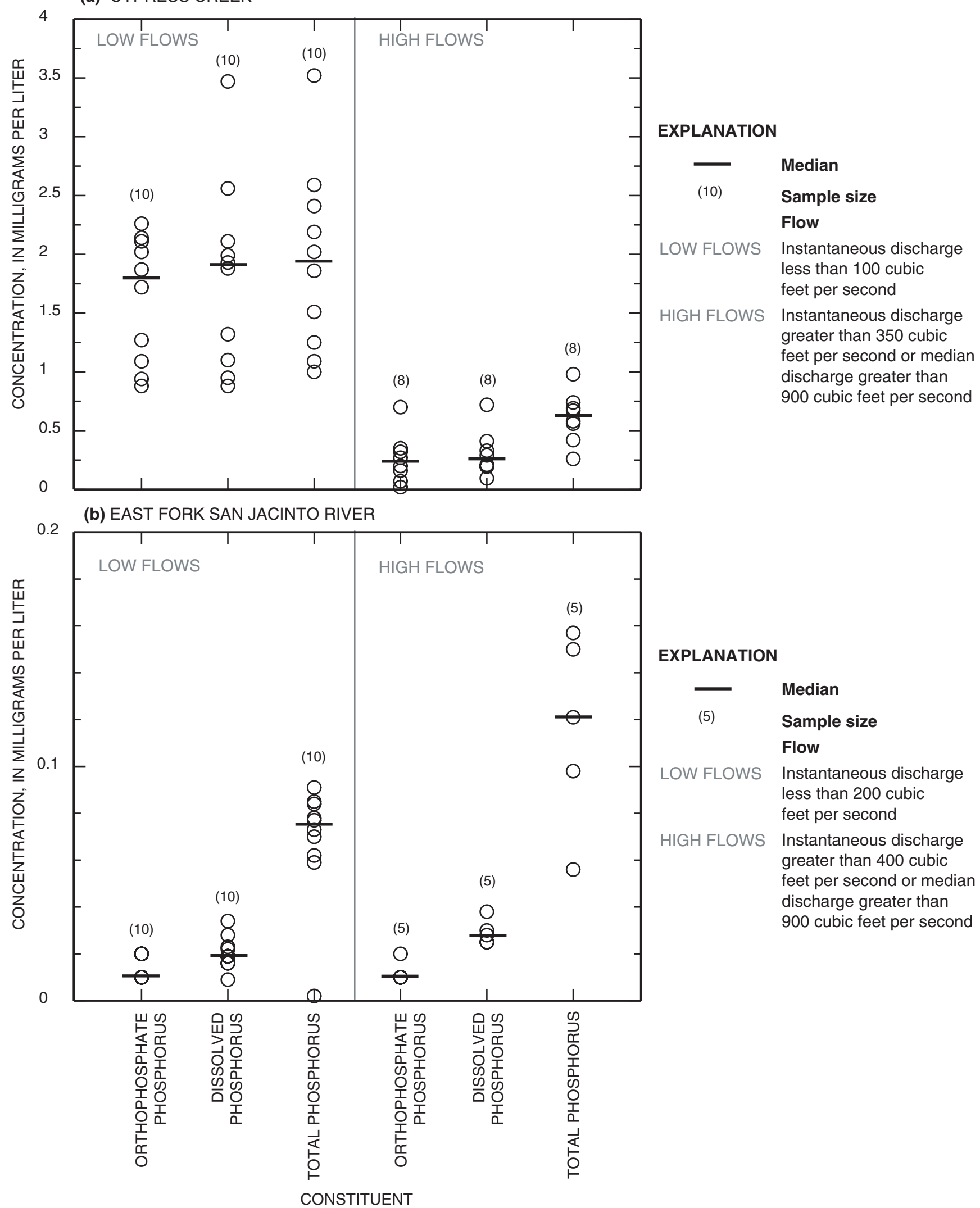

Figure 12. Distribution of orthophosphate phosphorus, dissolved phosphorus, and total phosphorus at low flows (June 2000-September 2004) and high flows (April 2002-November 2004) at (a) Cypress Creek and (b) East Fork San Jacinto River near Houston, Texas. 
(a) CYPRESS CREEK

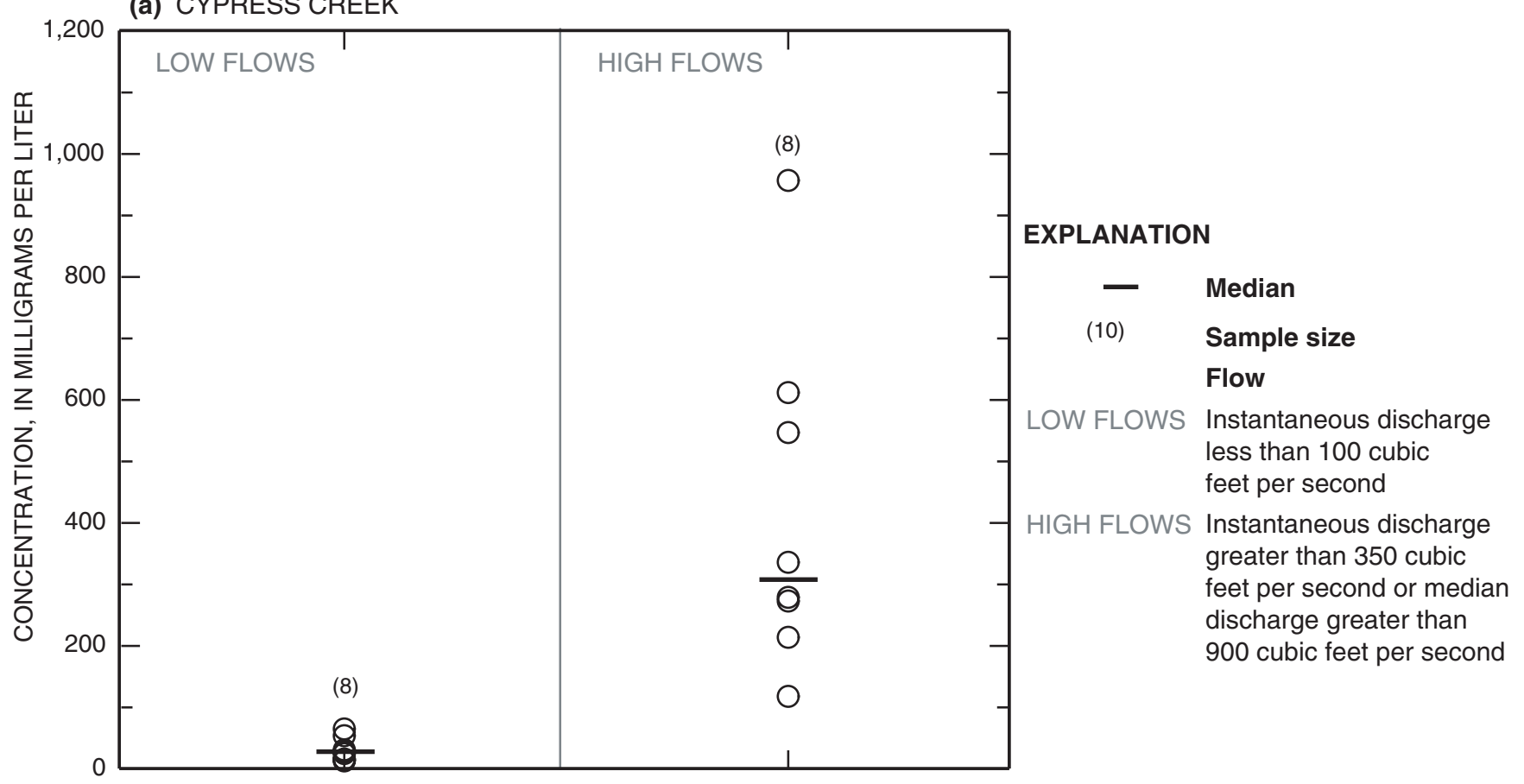

(b) EAST FORK SAN JACINTO RIVER

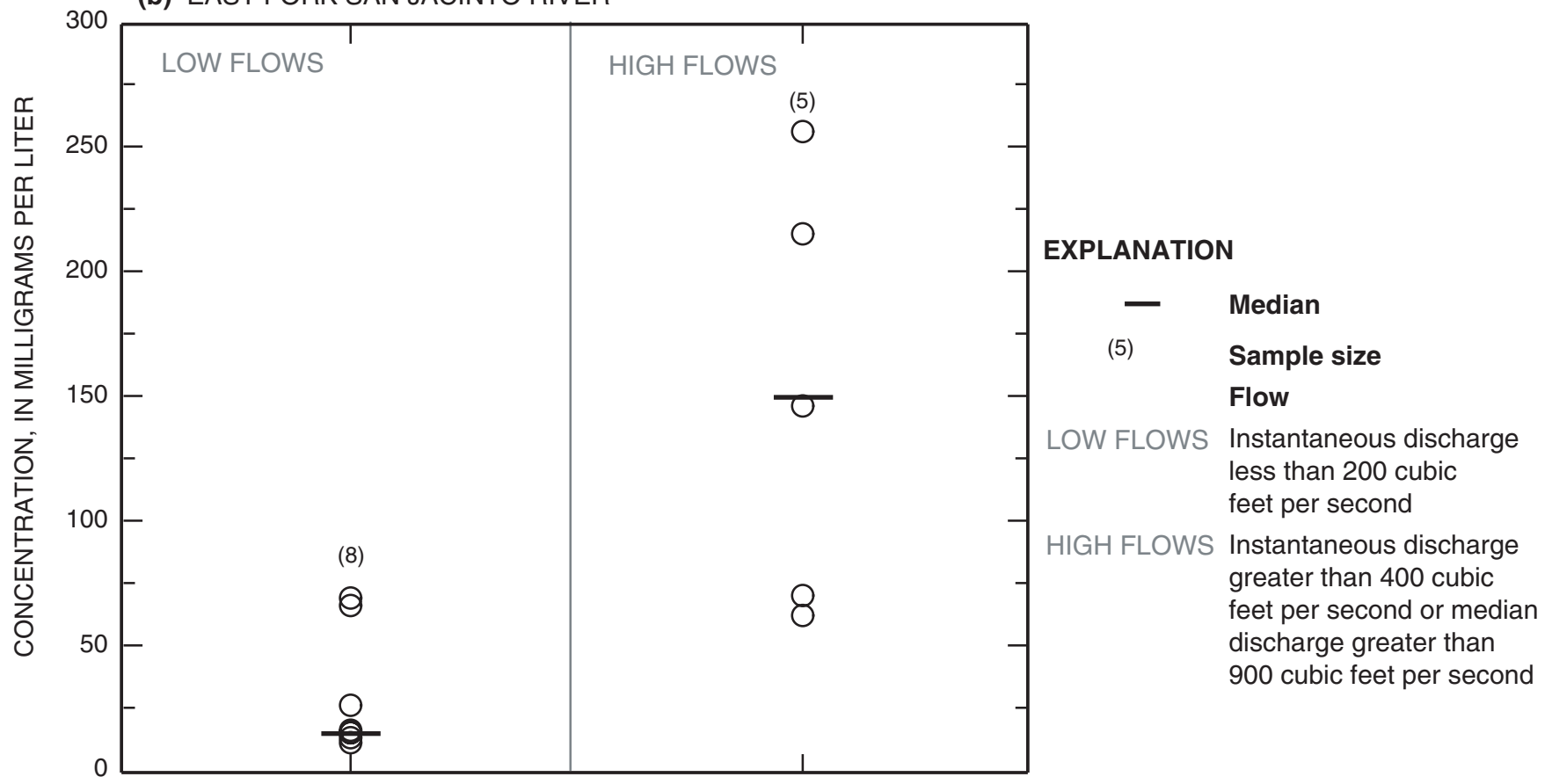

SUSPENDED SEDIMENT

Figure 13. Distribution of suspended sediment at low flows (June 2000-September 2004) and high flows (April 2002-November 2004) at (a) Cypress Creek and (b) East Fork San Jacinto River near Houston, Texas.

low and high flows, respectively. Diazinon, the most commonly detected insecticide in East Fork San Jacinto River, was detected in five of 15 samples. The largest concentration, 0.051 $\mathrm{mg} / \mathrm{L}$, was measured in a storm sample.

\section{Loads and Yields}

Low-flow and high-flow loads and yields were computed for selected constituents to determine (1) the relative low-flow 
(a) CYPRESS CREEK

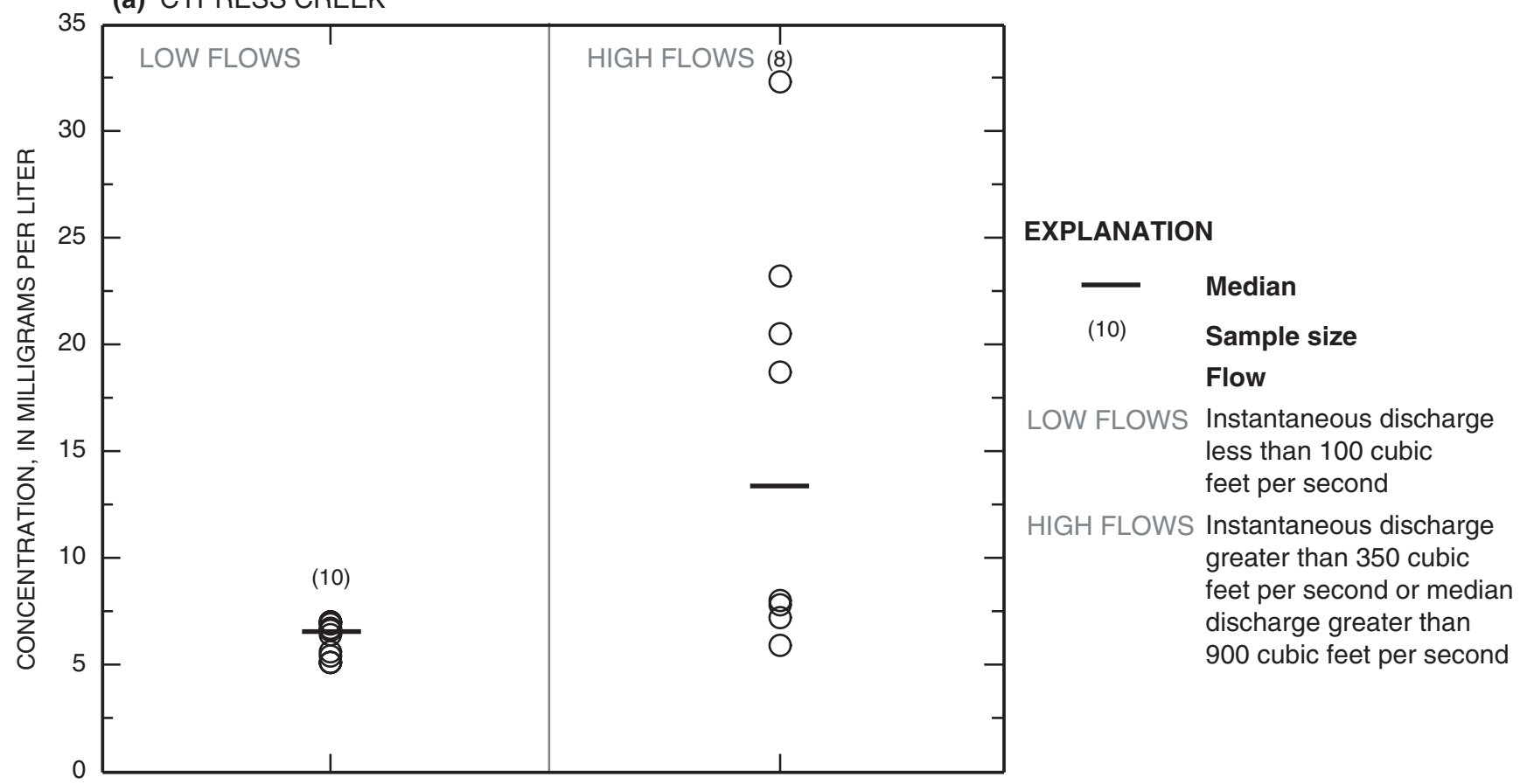

(b) EAST FORK SAN JACINTO RIVER

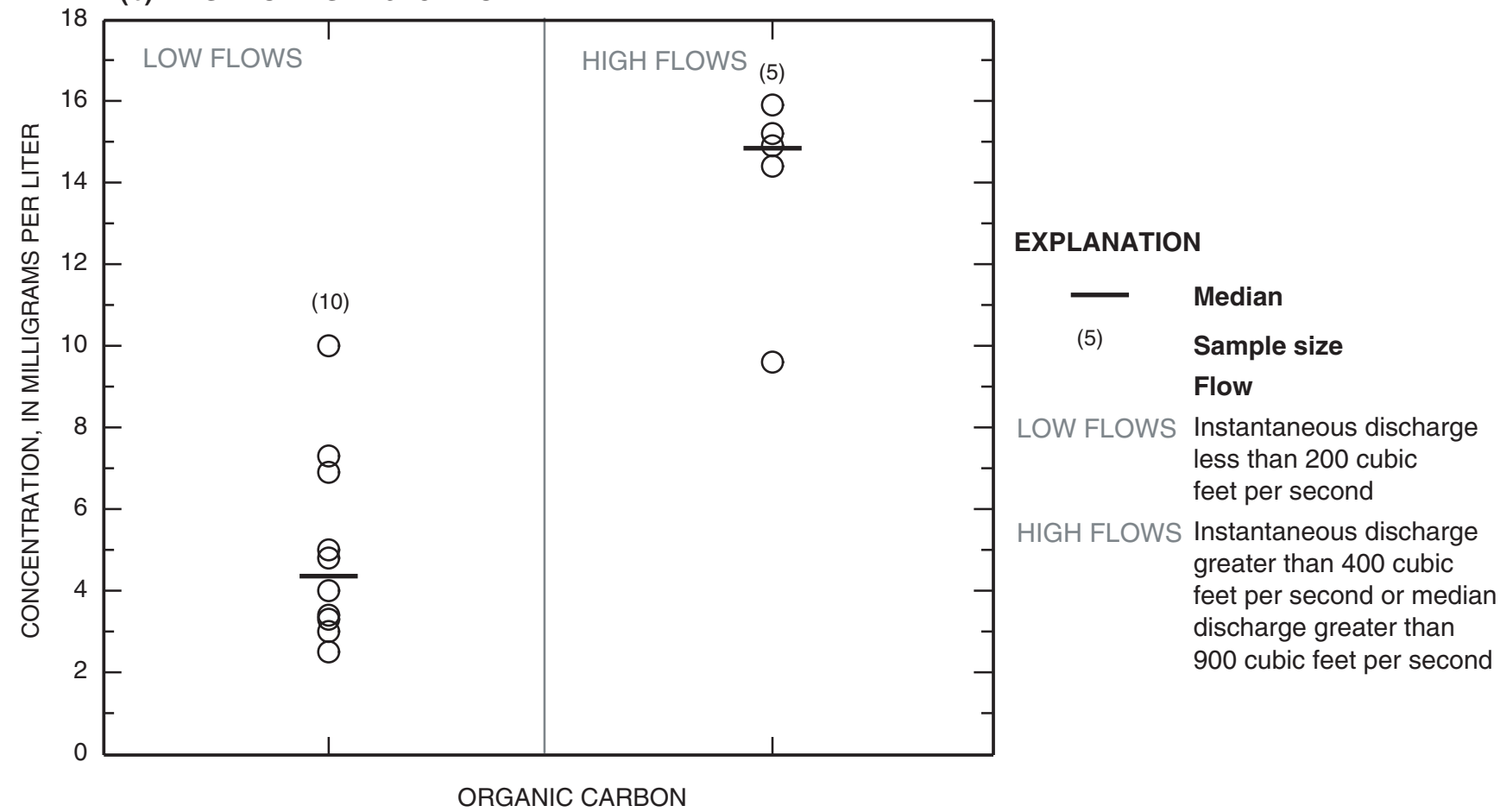

Figure 14. Distribution of organic carbon at low flows (June 2000-September 2004) and high flows (April 2002-November 2004) at (a) Cypress Creek and (b) East Fork San Jacinto River near Houston, Texas.

or storm contribution of constituents, in pounds per day, to Lake Houston from the Cypress Creek and East Fork San Jacinto River watersheds; and (2) the production, in pounds per square mile per day, of constituents within each watershed. Together, they provide some insight into conditions or practices within a watershed that might contribute to the overall quality of water that flows from that watershed. The computed loads and yields for selected constituents from Cypress Creek and East Fork San Jacinto River are listed in tables 6-9. 
Table 6. Summary of minimum, median, and maximum loads of selected constituents at low flows and high flows in Cypress Creek near Houston, Texas, 2000-2004.

[lb, pounds; --, load not computed because analytical value less than minimum reporting level; CIAT, 2-chloro-4-isopropylamino-6-amino-s-triazine ]

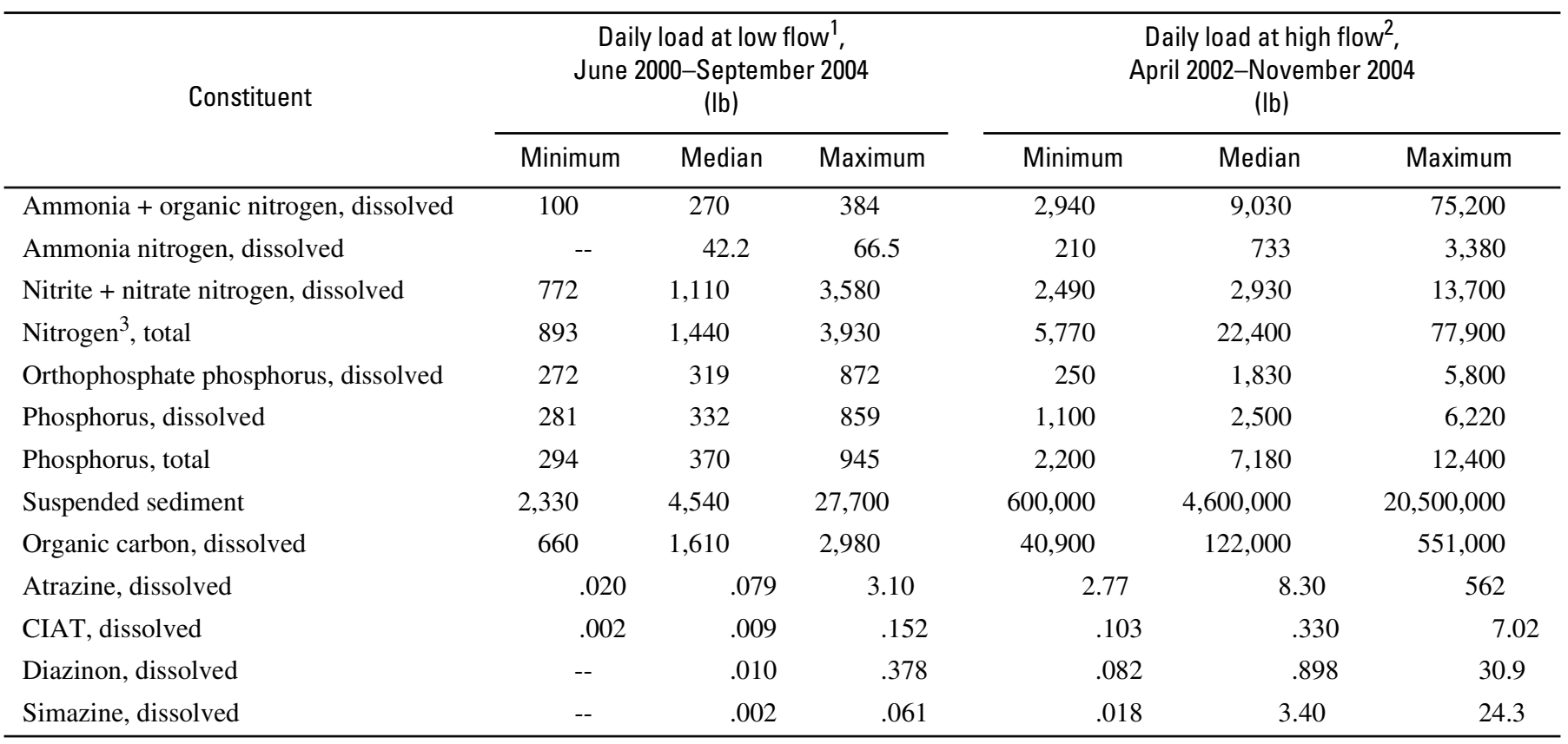

${ }^{1}$ Instantaneous discharge less than 100 cubic feet per second.

${ }^{2}$ Instantaneous discharge greater than 350 cubic feet per second or median discharge greater than 900 cubic feet per second.

${ }^{3}$ Nitrite + nitrate nitrogen plus ammonia + organic nitrogen.

Table 7. Summary of minimum, median, and maximum loads of selected constituents at low flows and high flows in East Fork San Jacinto River near Houston, Texas, 2000-2004.

[lb, pounds; --, load not computed because analytical value less than minimum reporting level; CIAT, 2-chloro-4-isopropylamino-6-amino-s-triazine]

\begin{tabular}{|c|c|c|c|c|c|c|}
\hline Constituent & \multicolumn{3}{|c|}{$\begin{array}{c}\text { Daily load at low flow }{ }^{1} \\
\text { June } 2000-\text { September } 2004 \\
\text { (lb) }\end{array}$} & \multicolumn{3}{|c|}{$\begin{array}{c}\text { Daily load at high flow }{ }^{2} \\
\text { April 2002-November } 2004 \\
\text { (lb) }\end{array}$} \\
\hline Ammonia + organic nitrogen, dissolved & 11.0 & 50.2 & 379 & 2,640 & 4,390 & 16,900 \\
\hline Ammonia nitrogen, dissolved & -- & -- & 25.2 & -- & -- & -- \\
\hline Phosphorus, dissolved & 1.23 & 5.10 & 19.4 & 122 & 208 & 1,370 \\
\hline Phosphorus, total & -- & 15.6 & 65.6 & 417 & 947 & 3,530 \\
\hline Suspended sediment & 1,040 & 7,370 & 28,800 & 342,000 & $1,620,000$ & $2,600,000$ \\
\hline Organic carbon, dissolved & 220 & 1,090 & 8,410 & 72,800 & 116,000 & 548,000 \\
\hline
\end{tabular}

\footnotetext{
${ }^{1}$ Instantaneous discharge less than 200 cubic feet per second.

${ }^{2}$ Instantaneous discharge greater than 400 cubic feet per second or median discharge greater than 900 cubic feet per second.

${ }^{3}$ Nitrite + nitrate nitrogen plus ammonia + organic nitrogen.
} 
Table 8. Summary of minimum, median, and maximum yields of selected constituents at low flows and high flows in Cypress Creek near Houston, Texas, 2000-2004.

$\left[\mathrm{lb} / \mathrm{mi}^{2}\right.$, pounds per square mile; --, load not computed because analytical value less than minimum reporting level; CIAT, 2-chloro-4-isopropylamino-6-amino-striazine]

\begin{tabular}{|c|c|c|c|c|c|c|}
\hline Constituent & \multicolumn{3}{|c|}{$\begin{array}{l}\text { Daily yield at low flow }{ }^{1}, \\
\text { June } 2000-\text { September } 2004 \\
\left(\mathrm{lb} / \mathrm{mi}^{2}\right)\end{array}$} & \multicolumn{3}{|c|}{$\begin{array}{c}\text { Daily yield at high flow }{ }^{2} \\
\text { April 2002-November } 2004 \\
\left(\mathrm{lb} / \mathrm{mi}^{2}\right)\end{array}$} \\
\hline Ammonia + organic nitrogen, dissolved & 0.329 & 0.885 & 1.26 & 9.64 & 29.6 & 247 \\
\hline Ammonia nitrogen, dissolved & -- & .138 & .218 & .688 & 2.40 & 11.1 \\
\hline Nitrogen, total & 2.93 & 4.71 & 12.9 & 18.9 & 73.3 & 255 \\
\hline Orthophosphate phosphorus, dissolved & .89 & 1.05 & 2.86 & .820 & 6.00 & 19.0 \\
\hline Phosphorus, dissolved & .92 & 1.09 & 2.82 & 3.61 & 8.20 & 20.4 \\
\hline Phosphorus, total & .96 & 1.21 & 3.10 & 7.23 & 23.6 & 40.8 \\
\hline Suspended sediment & 7.64 & 14.9 & 90.8 & 1,970 & 15,100 & 67,400 \\
\hline Diazinon, dissolved & -- & $3.35 \times 10^{-05}$ & .001 & .0003 & .003 & .101 \\
\hline Simazine, dissolved & -- & $6.79 \times 10^{-06}$ & .0002 & $6.1 \times 10^{-05}$ & .011 & .080 \\
\hline
\end{tabular}

${ }^{1}$ Instantaneous flow less than 100 cubic feet per second.

${ }^{2}$ Instantaneous flow greater than 350 cubic feet per second or median flow greater than 900 cubic feet per second.

Table 9. Summary of minimum, median, and maximum yields of selected constituents at low flows and high flows in East Fork San Jacinto River near Houston, Texas, 2000-2004.

[lb/mi², pounds per square mile; --, load not computed because analytical value less than minimum reporting level; CIAT, 2-chloro-4-isopropylamino-6-amino-striazine]

\begin{tabular}{|c|c|c|c|c|c|c|}
\hline \multirow[t]{2}{*}{ Constituent } & \multicolumn{3}{|c|}{ 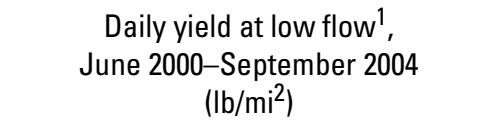 } & \multicolumn{3}{|c|}{$\begin{array}{c}\text { Daily yield at high flow }{ }^{2} \\
\text { April 2002-November } 2004 \\
\left(\mathrm{lb} / \mathrm{mi}^{2}\right)\end{array}$} \\
\hline & Minimum & Median & Maximum & Minimum & Median & Maximum \\
\hline Ammonia + organic nitrogen, dissolved & 0.027 & 0.124 & 0.937 & 6.53 & 10.9 & 41.9 \\
\hline Ammonia nitrogen, dissolved & -- & -- & .062 & -- & -- & -- \\
\hline Nitrite + nitrate nitrogen, dissolved & -- & .091 & .292 & -- & -- & 1.47 \\
\hline Nitrogen, dissolved & .040 & .252 & 1.14 & -- & -- & -- \\
\hline Phosphorus, dissolved & .003 & .013 & .048 & .302 & .516 & 3.39 \\
\hline Phosphorus, total & -- & .038 & .162 & 1.03 & 2.34 & 8.74 \\
\hline Suspended sediment & 2.56 & 18.2 & 71.4 & 847 & 4,000 & 6,430 \\
\hline Organic carbon, dissolved & .545 & 2.69 & 20.8 & 180 & 287 & 1,360 \\
\hline Atrazine, dissolved & -- & -- & $3.75 \times 10^{-05}$ & -- & .0006 & .004 \\
\hline CIAT, dissolved & -- & -- & -- & -- & -- & .0001 \\
\hline Diazinon, dissolved & -- & -- & $2.29 \times 10^{-05}$ & -- & .0004 & .0009 \\
\hline
\end{tabular}

${ }^{1}$ Instantaneous flow less than 200 cubic feet per second.

${ }^{2}$ Instantaneous flow greater than 400 cubic feet per second or median flow greater than 900 cubic feet per second. 
The median daily storm load of total nitrogen for highflow samples (table 6) in Cypress Creek was more than 15 times larger than the median daily load for low-flow samples. The principal contributor to the total nitrogen load at low flows was nitrite plus nitrate nitrogen; at high flows, the principal contributor was ammonia plus organic nitrogen.

Dissolved nitrogen loads in East Fork San Jacinto River could not be computed for all samples when concentrations of nitrite plus nitrate nitrogen, a part of the computation, were less than the MRL. Where relative contributions could be determined, organic nitrogen was the dominant form of dissolved nitrogen (table 7).

Computed low-flow and high-flow yields of nitrogen compounds (tables 8,9 ) were appreciably larger in Cypress Creek than in East Fork San Jacinto River. Differences were most apparent at high flows, when surface runoff was a large contributor to measured concentrations. In Cypress Creek, storm yields of nitrite plus nitrate nitrogen during high flows ranged from about 8 to 45 pounds per square mile per day. In East Fork San Jacinto River, the maximum storm yield of nitrite plus nitrate nitrogen for high flows was 1.47 pounds per square mile per day.

The median daily load of dissolved phosphorus for low flows in Cypress Creek was about 65 times larger than that from East Fork San Jacinto River; the median daily load for high flows was about 12 times larger (tables 6, 7). At both sites, loads and yields of phosphorus increased considerably with discharge. In Cypress Creek, the median daily storm load of dissolved phosphorus for high flows (2,500 pounds) was 7.5 times larger than the median daily load for low flows (332 pounds) (table 6); in East Fork San Jacinto River, the median daily storm load of dissolved phosphorus for high flows (208 pounds) was 41 times larger than the median daily load for low flows (5.10 pounds) (table 7). Corresponding daily yields from Cypress Creek for low flows (1.09 pounds per square mile) and for high flows ( 8.20 pounds per square mile) (table 8 ) were 84 and 16 times, respectively, larger than corresponding daily yields from East Fork San Jacinto River for low flows ( 0.013 pound per square mile) and high flows ( 0.516 pound per square mile) (table 9).

Both Cypress Creek and East Fork San Jacinto River delivered considerable sediment loads to Lake Houston, especially during high flows. At Cypress Creek, the median daily storm load of suspended sediment for high flows was more than 1,000 times larger than the median daily load for low flows (table 6); the median daily storm load of suspended sediment for high flows in East Fork San Jacinto River was about 220 times larger than the median daily load for low flows (table 7). The median daily yield of suspended sediment for low flows was larger in East Fork San Jacinto River than in Cypress Creek, but the relation was reversed for high flows. The larger median daily storm yield of suspended sediment for high flows (3.8 times larger in Cypress Creek than in East Fork San Jacinto River) could reflect larger impermeable surface area associated with urbanization, loss of vegetation, and increased runoff to the stream. The maximum daily storm yield of suspended sediment for high flows was 67,400 pounds per square mile from Cypress Creek (table 8) and 6,430 pounds per square mile from East Fork San Jacinto River (table 9).

Median daily yields of dissolved organic carbon were larger in Cypress Creek than in East Fork San Jacinto River. The median daily yield of dissolved organic carbon for low flows in the Cypress Creek watershed was 5.27 pounds per square mile, and the median daily storm yield for high flows was 401 pounds per square mile (table 8). In East Fork San Jacinto River, median daily low-flow and storm yields of dissolved organic carbon were 2.69 and 287 pounds per square mile, respectively (table 9).

Data collected during this project supported national findings (U.S. Geological Survey, 1999) that urban areas can be a substantial source of pesticides. Concentrations of pesticides in Cypress Creek and East Fork San Jacinto River, as well as loads and yields, corresponded to the intensity of urbanization in the respective watersheds. Although daily loads and yields for most pesticides were small, the maximum daily load of atrazine for high flows from Cypress Creek was 562 pounds (table 6); the corresponding maximum daily yield for high flows was 1.84 pounds per square mile (table 8), 460 times larger than the maximum daily yield for high flows from East Fork San Jacinto River of 0.004 pound per square mile (table 9). However, because water for pesticide analyses was collected as discrete samples, and not during an entire storm, large atrazine concentrations might represent a slug of the compound in the water; the load and yield from the entire high-flow period might have been considerably different.

\section{Water-Quality Trends, 1990-2004}

Tests to indicate trends in the concentrations of selected constituents were done for each Lake Houston site. Initially, graphs of constituent concentrations with time were made to provide insight into possible trends. Seasonal Kendall tests were run on all of the data for each of the three sites, respectively. Then the data for each site were grouped by season and Kendall's tau tests were run to indicate possible trends during each season at a single site over time. The concentrations of most constituents at Lake Houston sites showed no trend during 1990-2004; however significant trends overall or for particular seasons, or both, were detected at some sites for nitrite plus nitrate nitrogen, dissolved phosphorus, dissolved organic carbon, chlorophyll- $a$, and diazinon (table 10).

The 1990-2004 dataset for nitrite plus nitrate nitrogen concentrations contained many nondetections and measured values only slightly larger than the reporting limit; therefore a graph of the constituent over time did not provide insight into possible trends. Seasonal Kendall tests indicated no significant trends in the collective data for each site. Kendall's tau tests on the data separated by season indicated one significant trend at site EC. Winter samples yielded an upward trend $(\mathrm{p}=.005)$.

Tests of the collective dissolved phosphorus data for 1990-2004 at each of the three sites showed significant downward trends at sites AC and EC ( $\mathrm{p}=.05$ and .012 , respectively). 
Table 10. Summary of statistical tests for trends in nitrite plus nitrate nitrogen, dissolved phosphorus, dissolved organic carbon, chlorophyll-a, and diazinon at three sites in Lake Houston near Houston, Texas, 1990-2004.

[Only constituents at sites with trends listed]

\begin{tabular}{lllll}
\hline \multicolumn{1}{c}{ Constituent } & Site & Statistical test & p-value & Results \\
\hline Nitrite plus nitrate nitrogen, dissolved & EC & Kendall's tau & .005 & Upward trend in winter \\
Phosphorus, dissolved & AC & Seasonal Kendall & .05 & Downward trend overall \\
& EC & Seasonal Kendall & .012 & Downward trend overall \\
Organic carbon, dissolved & EC & Kendall's tau & .052 & Downward trend in summer \\
& AC & Seasonal Kendall & .017 & Downward trend overall \\
Chlorophyll- $a$ phytoplankton & EC & Seasonal Kendall & .026 & Downward trend overall \\
& FC & Seasonal Kendall & .064 & Downward trend overall \\
Diazinon, dissolved & AC & Seasonal Kendall & .051 & Upward trend overall \\
\hline
\end{tabular}

${ }^{1}$ Period 2000-2004 only.

When concentrations by season were analyzed separately, a downward trend was indicated for summer concentrations at site EC, but the level of significance was .052.

Concentrations of dissolved organic carbon at sites AC and EC trended significantly downward for 1990-2004 ( $\mathrm{p}=$ .017 and .026 , respectively). The concentrations at site FC also trended downward, but the level of significance was .064. No significant trends were indicated in the seasonal data.

There was one trend indicated in the collective chlorophyll- $a$ data for 1990-2004. The seasonal Kendall test yielded an upward trend at a significance level of .051 for site AC. When data were analyzed separately by season, site AC showed a significant upward trend $(\mathrm{p}=.042)$ for summer concentrations.

Pesticide data were not available before 2000. Tests of atrazine and simazine yielded no significant trends in the 2000 2004 data. Diazinon showed a significant downward trend $(\mathrm{p}=.004)$ in collective concentrations at site AC. No seasonal trends were indicated.

\section{Implications}

Overall, the spatial distribution of chemical constituents in Lake Houston followed a general pattern of largest concentrations at site FC, smallest concentrations at site EC, and intermediate concentrations at site $\mathrm{AC}$ near the dam. Although there were few constituent trends in the lake relative to the number of constituents assessed, the findings indicate that urbanization in the western subbasin probably has affected water quality of streams flowing from the subbasin to Lake Houston. The findings also indicate that loads of nutrients, pesticides, and sediment supplied to the lake from the western subbasin could be large, especially during high flows. Moreover, although there was either no change or a decrease in most nutrient concentrations, chlorophyll- $a$ concentrations showed an overall increase at site $\mathrm{AC}$, which implies that factors other than nutrients might be important to algal growth in the lake. Collection and analysis of more frequent water samples at both stream inflow and lake sites could provide better resolution of the temporal supply of nutrients, pesticides, and sediment to Lake Houston and allow more comprehensive analysis of their effect on the lake.

\section{Summary}

Lake Houston is a major source of public water supply and recreational resource for the Houston metropolitan area, Texas. Because of its proximity to Houston, possible effects of urbanization on the quality of inflows to the lake and on the lake have been of concern to water managers. Although not on the State of Texas 2002 303(d) list for impairment by any water-quality constituents, Lake Houston was listed with "concerns" for nutrient enrichment (orthophosphorus, total phosphorus, nitrite plus nitrate nitrogen) and for aquatic life use (dissolved oxygen). Previous studies have found sufficient nutrients to cause problematic algal blooms as well as contaminants associated with urbanization in bed sediments. The Lake Houston drainage basin can be divided into two subbasins, the eastern subbasin, which is largely woodland, and the western subbasin, which is more urbanized. Land-cover types (developed and cultivated) that are related to an increased potential for nutrients and pesticide compounds in storm runoff encompass about three times the area in the western subbasin as in the eastern subbasin.

This report, prepared in cooperation with the City of Houston, assesses the water quality of Lake Houston on the basis of data collected during 2000-2004 and possible trends in selected 
constituents on the basis of data collected during 1990-2004. Water-quality samples were collected in Lake Houston, as well as at Cypress Creek (in the western subbasin) and East Fork San Jacinto River (in the eastern subbasin), during 2000-2004. Nitrogen compounds, phosphorus, suspended sediment, organic carbon, turbidity, and selected pesticide concentrations in water samples were assessed at all sites. Loads and yields were computed for selected constituents in Cypress Creek and East Fork San Jacinto River. Statistical tests used data collected during this study with previously collected data to identify possible water-quality trends in Lake Houston during 19902004.

Three sites were sampled in Lake Houston. These sites characterized water available to the City of Houston pumping station (site AC), water entering the lake from largely rural eastern watersheds (site EC), and water entering the lake from urbanized, western watersheds (site FC). Patterns of chemical and biological constituents in Lake Houston were affected by sedimentation and the water quality of inflowing streams. In general, conditions at the upstream end of the lake (sites EC and FC) were dominated by stream processes; site AC, near the dam, was dominated by lacustrine conditions. Most biological and chemical concentrations were largest at site FC, smallest at site EC, and intermediate at site AC.

Organic nitrogen was the dominant form of nitrogen in samples collected in Lake Houston. Nitrite plus nitrate nitrogen concentrations were largest near inflows from the more urbanized, western part of the drainage basin (site FC). Nitrite plus nitrate nitrogen contributed about 25 percent of the dissolved nitrogen in the lake near inflows (site EC) from the eastern subbasin. Concentrations of nitrite plus nitrate and ammonia plus organic nitrogen near the dam (site AC) were intermediate to those at sites EC and FC. About 63 percent of the total nitrogen at site $\mathrm{AC}$ was ammonia plus organic nitrogen. Total phosphorus concentrations in more than 97 percent of all samples were larger than $0.025 \mathrm{mg} / \mathrm{L}$, the level recommended by the USEPA to limit aquatic growth. There was a wide range in suspendedsediment concentrations and in turbidity in the lake. The majority of suspended-sediment concentrations ranged from 6 to 98 $\mathrm{mg} / \mathrm{L}$; concentrations at site FC were about twice those measured at site EC and three times those at AC. Turbidity ranged from 7 to 270 NTUs in Lake Houston. The maximum turbidity at site $\mathrm{AC}$ was about 10 times greater than the median value at that site. Concentrations of chlorophyll- $a$ in Lake Houston were small. Median values ranged from $6.8 \mu \mathrm{g} / \mathrm{L}$ at site AC to 16.4 $\mu \mathrm{g} / \mathrm{L}$ at site FC. Twelve pesticides were detected. Atrazine and its breakdown product, 2-chloro-4-isopropylamino-6-amino-striazine (CIAT), were the most commonly detected pesticides; atrazine concentrations were larger than the USEPA MCL of $3.0 \mu \mathrm{g} / \mathrm{L}$ in two samples at site $\mathrm{FC}$.

The relative contributions to the water quality of Lake Houston from the eastern and western subbasins were examined by collecting water samples from the inflow streams, Cypress Creek and East Fork San Jacinto River. At Cypress Creek, nitrite plus nitrate nitrogen accounted for about 86 percent of total nitrogen during low flows; at high flows, organic nitrogen contributed about 66 percent of the total nitrogen. Organic nitrogen was the dominant form of dissolved nitrogen at both low flows (about 60 percent) and high flows (about 88 percent) in East Fork San Jacinto River.

In Cypress Creek, about 94 percent of the total phosphorus at low flows was dissolved; at high flows about 50 percent was dissolved. Dissolved phosphorus concentrations exceeded 0.05 $\mathrm{mg} / \mathrm{L}$ in all samples at Cypress Creek. Dissolved phosphorus concentrations were about 10 times larger in Cypress Creek than in East Fork San Jacinto River. All samples at East Fork San Jacinto River had dissolved phosphorus detections; concentrations were less than $0.05 \mathrm{mg} / \mathrm{L}$.

Fifteen pesticides were detected in samples at Cypress Creek. Atrazine was detected in all samples at Cypress Creek; concentrations in three of 17 samples exceeded the USEPA MCL of $3.0 \mu \mathrm{g} / \mathrm{L}$. The largest concentration was $21.3 \mu \mathrm{g} / \mathrm{L}$ (high-flow sample). CIAT, diazinon, and simazine were detected in more than 82 percent of the samples. In samples at East Fork San Jacinto River, atrazine was the most frequently detected pesticide, present in six of 15 samples. The maximum atrazine concentration was $0.233 \mu \mathrm{g} / \mathrm{L}$ (high-flow sample). Diazinon was detected in five of 15 samples.

Constituent loads from the Cypress Creek and East Fork San Jacinto River watersheds were positively correlated with discharge. In Cypress Creek, the median daily storm load of total nitrogen for high flows was more than 15 times larger than the median daily load of total nitrogen for low flows; the median daily storm load of dissolved phosphorus for high flows was 7.5 times the median daily load for low flows; the median daily storm load of suspended sediment for high flows was more than 1,000 times the median daily load for low flows. In East Fork San Jacinto River, the median daily storm load of dissolved phosphorus for high flows was about 41 times larger than the median daily load for low flows; the median daily storm load of suspended sediment for high flows was about 220 times larger than the median daily load for low flows.

Constituent yields, which normalize differences in watershed size, allowed for direct comparison of loads from Cypress Creek and East Fork San Jacinto River. Daily yields of constituents in Cypress Creek were larger than those in East Fork San Jacinto River, especially during high flows. Daily yields of nitrite plus nitrate nitrogen for high flows ranged from about 8 to 45 pounds per square mile from Cypress Creek. In East Fork San Jacinto River, only the maximum daily yield of nitrite plus nitrate nitrogen, 1.47 pounds per square mile, could be computed for high flows. Median daily yields of dissolved phosphorus from Cypress Creek for low flows (1.09 pounds per square mile) and median daily yields for high flows (8.20 pounds per square mile) were 84 and 16 times larger, respectively, than corresponding yields from East Fork San Jacinto River for low flows (0.013 pound per square mile) and high flows (0.516 pound per square mile). The median daily yield of suspended sediment for low flows was larger from East Fork San Jacinto River than in Cypress Creek; however, at high flows, the relation was reversed. This reversal could reflect increased impermeable surface area associated with urbanization in the 
Cypress Creek watershed, loss of vegetation, and increased stream runoff. The maximum daily yield of suspended sediment computed during this study for high flows was 67,400 pounds per square mile from Cypress Creek. Daily yields of most pesticides were small; however the maximum daily yield of atrazine from the Cypress Creek watershed was 1.84 pounds per square mile. In contrast, the maximum daily yield of atrazine from East Fork San Jacinto River was 0.004 pound per square mile.

Concentrations of selected constituents in water samples from the Lake Houston sites for 1990-2004 were tested for trends. Seasonal Kendall tests were run on all of the data for each of the three sites, respectively. Kendall's tau tests were run on the data for each site grouped by season. The concentrations of most constituents at Lake Houston sites showed no trend for 1990-2004; however significant trends overall or for particular seasons, or both, were detected at some sites for nitrite plus nitrate nitrogen, dissolved phosphorus, dissolved organic carbon, chlorophyll- $a$, and diazinon (2000-2004 data only for diazinon).

Overall, the spatial distribution of chemical constituents in Lake Houston followed a general pattern of largest concentrations at site FC, smallest concentrations at site EC, and intermediate concentrations at site AC. Although there were few constituent trends in the lake relative to the number of constituents assessed, the findings indicate that urbanization in the western subbasin probably has affected water quality of streams flowing into Lake Houston. Collection of a much larger number of water samples at each site could provide better resolution of the temporal supply of nutrients, pesticides, and sediment to Lake Houston and allow more comprehensive analysis of their effect on the lake.

\section{References}

Aragon Long, S.C., Reece, B.D., and Eames, D.R., 2005, Water resources data, Texas, water year 2004-Volume 3. San Jacinto River Basin, Brazos River Basin, San Bernard River Basin, and intervening coastal basins: U.S. Geological Survey Water-Data Report TX-04-3, 536 p.

Fishman, M.J., Raese, J.W., Gerlitz, C.N., and Husband, R.A., 1994, U.S. Geological Survey approved inorganic and organic methods for the analysis of water and fluvial sediment, 1954-94: U.S. Geological Survey Open-File Report 94-351, 55 p.

Fujii, Roger, Ranalli, A.J., Aiken, G.R., and Bergamaschi, B.A., 1998, Dissolved organic carbon concentrations and compositions, and trihalomethane formation potentials in waters from agricultural peat soils, Sacramento-San Joaquin delta, California-Implications for drinking-water quality: U.S. Geological Survey Water-Resources Investigations Report 98-4147, $75 \mathrm{p}$.

Gandara, S.C., 2002, Water resources data, Texas, water year 2001-Volume 3. San Jacinto River Basin, Brazos River Basin, San Bernard River Basin, and intervening coastal basins: U.S. Geological Survey Water-Data Report TX-01-3, $460 \mathrm{p}$.

Gandara, S.C., 2003, Water resources data, Texas, water year 2002-Volume 3. San Jacinto River Basin, Brazos River

Basin, San Bernard River Basin, and intervening coastal basins: U.S. Geological Survey Water-Data Report TX-02-3, $476 \mathrm{p}$.

Gandara, S.C., 2004, Water resources data, Texas, water year 2003-Volume 3. San Jacinto River Basin, Brazos River Basin, San Bernard River Basin, and intervening coastal basins: U.S. Geological Survey Water-Data Report TX-03-3, $474 \mathrm{p}$.

Gandara, S.C., Gibbons, W.J., and Barbie, D.L., 2001, Water resources data, Texas, water year 2000-Volume 3. San Jacinto River Basin, Brazos River Basin, San Bernard River Basin, and intervening coastal basins: U.S. Geological Survey Water-Data Report TX-00-3, 490 p.

Guy, H.P., 1969, Laboratory theory and methods for sediment analysis: U.S. Geological Survey Techniques of WaterResources Investigations, book 5, ch. C1, 58 p.

Harris-Galveston Coastal Subsidence District, 1999 [amended 2001], District regulatory plan: accessed September 16, 2005, at http://www.subsidence.org/PDF_Files/ HGRegPlan.pdf

Helsel, D.R., and Hirsch, R.M., 1992, Studies in environmental science 49-Statistical methods in water resources: Amsterdam, Elsevier, 522 p.

Hem, J.D., 1985, Study and interpretation of the chemical characteristics of natural water (3d ed.): U.S. Geological Survey Water-Supply Paper 2254, $263 \mathrm{p}$.

Houston-Galveston Area Council, 2004. How's the water?2004 basin highlights report: Harris-Galveston Area Council, Community and Environmental Planning Department, 44 p.

Kasmarek, M.C., and Houston, N.A., 2005, Water-level altitudes 2005 and water-level changes in the Chicot, Evangeline, and Jasper aquifers and compaction 1973-2004 in the Chicot and Evangeline aquifers, Houston-Galveston region, Texas: U.S. Geological Survey Open-File Report 2005-1128, 15 sheets.

Lane, S.L., Flanagan, Sarah, and Wilde, F.D., 2003, Selection of equipment for water sampling (version 2.0): U.S. Geological Survey Techniques of Water-Resources Investigations, book 9, chap. A2, accessed May 2004 at http://pubs.water.usgs.gov/twri9A2/.

LeChevallier, M.W., Evans, T.M., and Seidler, R.J., 1981, Effect of turbidity on chlorination efficiency and bacterial persistence in drinking water: Journal of American Water Works Association, v. 89, no. 9, p. 159-167.

Lee, R.W., and Rast, Walter, 1997, Light attenuation in a shallow, turbid reservoir, Lake Houston, Texas: U.S. Geological Survey Water-Resources Investigations Report 97-4064, $33 \mathrm{p}$.

Liscum, Fred, and East, J.W., 2000, Estimated effects on water quality of Lake Houston from interbasin transfer of water from the Trinity River, Texas: U.S. Geological Survey Water-Resources Investigations Report 00-4082, 50 p. 
Liscum, Fred, Goss, R.L., and Rast, Walter, 1999, Characteristics of water-quality data for Lake Houston, selected tributary inflows to Lake Houston, and the Trinity River near Houston (a potential source of interbasin transfer), August 1983September 1990: U.S. Geological Survey Water-Resources Investigations Report 99-4129, 56 p.

LJA Engineering \& Surveying, Inc., 2000, For your information-Houston hits the surface: LJA Insights, v. 5, issue 1, accessed September 16, 2005, at http://www.ljaengineering.com/newsletter/vol5issue1/default.html

Mueller, D.K., Martin, J.D., and Lopes, T.J., 1997, Quality-control design for surface-water sampling in the National WaterQuality Assessment Program: U.S. Geological Survey OpenFile Report 97-223, 17 p.

Myers, D.N., and Wilde, F.D., eds., 2003, National field manual for the collection of water-quality data-Biological indicators: U.S. Geological Survey Techniques of Water-

Resources Investigations, book 9, ch. A7, 163 p.

National Oceanic and Atmospheric Administration, 2005, Southeast Texas climate data: National Weather Service Forecast Office, Houston/Galveston, Texas, accessed February 7, 2005, at http://www.srh.noaa.gov/hgx/climate.htm

Porter, S.D., Cuffney, T.F., Gurtz, M.E., and Meador, M.R., 1993, Methods for collecting algal samples as part of the National Water-Quality Assessment Program: U.S. Geological Survey Open-File Report 93-409, 39 p.

Potter, B.B., and Wimsatt, J.C., 2003, Determination of total organic carbon and specific UV absorbance at $254 \mathrm{~nm}$ in source water and drinking water: U.S. Environmental Protection Agency, Office of Research and Development, National Exposure Research Laboratory, Method 415.3, 56 p.

Sandstrom, M.W., Stroppel, M.E., Foreman, W.T., and Schroeder, M.P., 2001, Methods of analysis by the U.S. Geological Survey National Water Quality LaboratoryDetermination of moderate-use pesticides and selected degradates in water by $\mathrm{C}-18$ solid-phase extraction and gas chromatography/mass spectrometry: U.S. Geological Survey Water-Resources Investigations Report 01-4098, $70 \mathrm{p}$.

Shelton, L.R., 1994, Field guide for collecting and processing stream-water samples for the National Water-Quality Assessment Program: U.S. Geological Survey Open-File Report 94-455, $42 \mathrm{p}$.

Terrio, P.J., 1995, Water-quality assessment of the upper Illinois River Basin in Illinois, Indiana, and WisconsinNutrients, dissolved oxygen, and fecal-indicator bacteria in surface water, April 1987 through August 1990: U.S. Geological Survey Water-Resources Investigations Report 95-4005, $79 \mathrm{p}$.

Texas Commission on Environmental Quality, 2002, 2002 Texas water quality inventory and 303(d) list: accessed September 19, 2005, at http://www.tceq.state.tx.us/ compliance/monitoring/water/quality/data/02twqi/ twqi02.html

Texas State Climatologist, 2004, Texas climatic bulletin: Office of the Texas State Climatologist, College of Geosciences, Department of Atmospheric Sciences, Texas A\&M University, accessed June 1, 2005, at http://www.met.tamu.edu/ osc/TXclimat.htm

Texas State Data Center, 2004, 2003 Total population estimates for Texas statistical metropolitan areas: Office of the State Demographer, Texas Population Estimates and Projections Program, accessed January 15, 2005, at http://txsdc.utsa.edu/ tpepp/2003_txpopest_msa.php

Texas Water Development Board, 2004, Reservoir volumetric surveys, priority reservoirs: accessed September 15, 2005, at http://www.twdb.state.tx.us/assistance/lakesurveys/ prioritylks.asp

Thornton, K.W., Kimmel, B.L., and Forrest, E.P., 1990, Reservoir limnology: New York, Wiley, 246 p.

U.S. Environmental Protection Agency, 1986, Quality criteria for water-1986: U.S. Environmental Protection Agency, Report 440/5-86-001 [variously paged].

U.S. Environmental Protection Agency, 1999, National Primary Drinking Water Regulations technical fact sheets: U.S. Environmental Protection Agency, Office of Water, Office of Ground Water and Drinking Water, accessed March 8, 2005, at http://www.epa.gov/OGWDW/hfacts.html

U.S. Environmental Protection Agency, 2004, 2004 edition of the drinking water standards and health advisories: U.S. Environmental Protection Agency, Office of Water, EPA 822-R-04-005, 12 p.

U.S. Geological Survey, 1999, The quality of our Nation's waters-Nutrients and pesticides: U.S. Geological Survey Circular 1225, $82 \mathrm{p}$.

U.S. Geological Survey, variously dated, National field manual for the collection of water-quality data: U.S. Geological Survey Techniques of Water-Resources Investigations, book 9, chaps. A1-A9, accessed at http://pubs.water.usgs.gov/ twri9A

Van Metre, P.C., and Sneck-Fahrer, D.A., 2002, Water-quality trends in suburban Houston, Texas, 1954-97, as indicated by sediment cores from Lake Houston: U.S. Geological Survey Fact Sheet 040-02, 6 p.

Wershaw, R.L., Fishman, M.J., Grabbe, R.R., and Lowe, L.E., eds., 1987, Methods for the determination of organic substances in water and fluvial sediments: U. S. Geological Survey Techniques of Water-Resources Investigations, book 5, ch. A3, 80 p.

Weyer, P.J., Cerhan, J.R., Kross, B.C., Hallberg, G.R., Kantamneni, J., Breuer, George, Jones, M.P., Zheng, Wei, and Lynch, C.F., 2001, Municipal drinking water nitrate level and cancer risk in older women-The Iowa women's health study: Epidemiology, v. 2, no. 3, p. 327-338. 
Blank Page 


\section{Appendixes}


Blank Page 
Appendix 1. Statistical summary of field measurements and physical properties, major cations and anions, nutrients, biological constituents, trace elements, and pesticides at Lake Houston, site AC, February 2000-September 2004.

[ $\geq$, equal to or greater than; $\mu \mathrm{S} / \mathrm{cm}$, microsiemens per centimeter at 25 degrees Celsius; ${ }^{\circ} \mathrm{C}$, degrees Celsius; mg/L, milligrams per liter; <, less than; m, meters; NTU, nephelometric turbidity units; UV, ultraviolet; $\mathrm{cm}$, centimeters; $\mathrm{CaCO}_{3}$, calcium carbonate; --, not applicable or not computed; cols./100 mL, colonies per 100 milliliters, E, estimated; $\mu \mathrm{g} / \mathrm{L}$, micrograms per liter]

\begin{tabular}{|c|c|c|c|c|c|c|c|c|}
\hline Constituent & $\begin{array}{l}\text { Num- } \\
\text { ber of } \\
\text { sam- } \\
\text { ples }\end{array}$ & $\begin{array}{l}\text { Mini- } \\
\text { mum } \\
\text { report- } \\
\text { ing } \\
\text { level }\end{array}$ & $\begin{array}{l}\text { Number of } \\
\text { detections } \\
\geq \text { reporting } \\
\quad \text { level }\end{array}$ & \multicolumn{5}{|c|}{ Concentration } \\
\hline \multicolumn{9}{|l|}{ Field measurements and physical properties } \\
\hline Specific conductance, unfiltered $(\mu \mathrm{S} / \mathrm{cm})$ & 15 & 0.1 & 15 & 124 & 158 & 192 & 232 & 327 \\
\hline Water temperature $\left({ }^{\circ} \mathrm{C}\right)$ & 15 & .1 & 15 & 11.3 & 15.9 & 27.8 & 29.4 & 30.5 \\
\hline Dissolved oxygen (mg/L) & 15 & .1 & 15 & 5.4 & 5.9 & 7.4 & 8.3 & 10.0 \\
\hline Residue, dissolved (mg/L) & 15 & 10 & 15 & 96 & 102 & 125 & 139 & 190 \\
\hline Residue, suspended (mg/L) & 15 & 10 & 8 & $<10$ & $<10$ & 10 & 14 & 26 \\
\hline Color (platinum cobalt units) & 15 & 1 & 15 & 25 & 40 & 80 & 170 & 350 \\
\hline UV absorbance, 254 nanometers (units/cm) & 15 & .0035 & 15 & .124 & .204 & .286 & .340 & .461 \\
\hline UV absorbance, 280 nanometers (units/cm) & 15 & .0035 & 15 & .091 & .149 & .213 & .249 & .347 \\
\hline \multicolumn{9}{|l|}{ Major cations and anions (mg/L) } \\
\hline Hardness (as $\mathrm{CaCO}_{3}$ ), total & 15 & 1 & 15 & 38 & 41 & 48 & 51 & 61 \\
\hline Calcium, dissolved & 15 & .02 & 15 & 12.2 & 13.4 & 15.9 & 16.9 & 19.8 \\
\hline Magnesium, dissolved & 15 & .008 & 15 & 1.72 & 1.84 & 2.05 & 2.27 & 2.70 \\
\hline Potassium, dissolved & 15 & .16 & 15 & 2.30 & 2.65 & 3.18 & 3.67 & 3.88 \\
\hline Sodium, dissolved & 15 & .20 & 15 & 8.49 & 12.3 & 17.8 & 25.0 & 41.3 \\
\hline Alkalinity (as $\mathrm{CaCO}_{3}$ ), dissolved & 14 & 1 & 14 & 25 & 36 & 40 & 56 & 67 \\
\hline Bicarbonate, dissolved & 14 & 1 & 14 & 31 & 43 & 48 & 68 & 78 \\
\hline Ammonia + organic nitrogen, dissolved & 15 & .10 & 15 & .27 & .34 & .38 & .48 & .73 \\
\hline Ammonia + organic nitrogen, total & 15 & .10 & 15 & .55 & .62 & .72 & .75 & .84 \\
\hline Ammonia nitrogen, dissolved & 15 & .04 & 1 & $<.04$ & $<.04$ & $<.04$ & $<.04$ & E.04 \\
\hline Nitrite + nitrate nitrogen, dissolved & 15 & .06 & 9 & $<.06$ & $<.06$ & .20 & .41 & .59 \\
\hline Nitrite nitrogen, dissolved & 15 & .010 & 2 & $<.010$ & $<.010$ & $<.010$ & $<.010$ & .021 \\
\hline Nitrogen ${ }^{1}$, dissolved & 9 & -- & -- & .33 & .64 & .83 & 1.0 & 1.1 \\
\hline Nitrogen ${ }^{1}$, total & 9 & -- & -- & .64 & .96 & 1.1 & 1.2 & 1.3 \\
\hline Orthophosphate phosphorus, dissolved & 15 & .018 & 15 & .03 & .05 & .06 & .12 & .16 \\
\hline Phosphorus, dissolved & 15 & .004 & 15 & .038 & .059 & .080 & .138 & .176 \\
\hline Phosphorus, total & 15 & .004 & 15 & .082 & .120 & .159 & .210 & .240 \\
\hline Organic carbon, dissolved & 15 & .33 & 15 & 4.5 & 6.5 & 8.4 & 9.7 & 12.1 \\
\hline Organic carbon, total & 15 & .40 & 15 & 6.4 & 8.5 & 10.7 & 11.8 & 14.1 \\
\hline
\end{tabular}

Footnote at end of table. 
Appendix 1. Statistical summary of field measurements and physical properties, major cations and anions, nutrients, biological constituents, trace elements, and pesticides at Lake Houston, site AC, February 2000-September 2004—Continued.

\begin{tabular}{|c|c|c|c|c|c|c|c|c|}
\hline Constituent & $\begin{array}{l}\text { Num- } \\
\text { ber of } \\
\text { sam- } \\
\text { ples }\end{array}$ & $\begin{array}{l}\text { Mini- } \\
\text { mum } \\
\text { report- } \\
\text { ing } \\
\text { level }\end{array}$ & $\begin{array}{c}\text { Number of } \\
\text { detections } \\
\geq \text { reporting } \\
\quad \text { level }\end{array}$ & \multicolumn{5}{|c|}{ Concentration } \\
\hline \multicolumn{9}{|l|}{ Biological constituents } \\
\hline Plankton, biomass, ash weight & 15 & 0.1 & 15 & 255 & 334 & 364 & 662 & 1,370 \\
\hline Biomass/chlorophyll ratio, plankton (number) & 13 & -- & -- & 330 & 439 & 2,020 & 11,600 & 30,000 \\
\hline E. coli bacteria (cols./100 mL) & 15 & 1 & 15 & E1 & 2 & 34 & 72 & 160 \\
\hline Fecal coliform bacteria (cols./100 mL) & 15 & 1 & 15 & E1 & 4 & 34 & 160 & 380 \\
\hline Fecal streptococcus bacteria (cols./100 mL) & 15 & 1 & 15 & E1 & 4 & 28 & 150 & 230 \\
\hline Chlorophyll- $a$ phytoplankton $(\mu \mathrm{g} / \mathrm{L})$ & 15 & .1 & 15 & .3 & 2.1 & 6.8 & 13.6 & 25.8 \\
\hline Antimony, dissolved & 15 & .2 & 4 & $<.20$ & $<.20$ & $<.20$ & .22 & .35 \\
\hline Arsenic, dissolved & 15 & 2.0 & 9 & $<2.0$ & $<2.0$ & 2.0 & 3.5 & 8.0 \\
\hline Barium, dissolved & 15 & .2 & 15 & 47 & 50 & 56 & 64 & 108 \\
\hline Beryllium, dissolved & 12 & .06 & 1 & $<.06$ & $<.06$ & $<.06$ & $<.06$ & .09 \\
\hline Cadmium, dissolved & 12 & .04 & 0 & -- & -- & -- & -- & -- \\
\hline Chromium, dissolved & 14 & .8 & 0 & -- & -- & -- & -- & -- \\
\hline Cobalt, dissolved & 12 & .014 & 12 & .096 & .118 & .164 & .247 & .281 \\
\hline Copper, dissolved & 15 & .4 & 15 & .8 & 1.5 & 1.8 & 3.0 & 4.5 \\
\hline Iron, dissolved & 15 & 10 & 12 & $<10$ & 11 & 33 & 93 & 545 \\
\hline Lead, dissolved & 12 & .08 & 8 & $<.08$ & $<.08$ & .13 & .21 & 1.72 \\
\hline Uranium, dissolved & 12 & .04 & 12 & .09 & .14 & .17 & .22 & .27 \\
\hline Zinc, dissolved & 15 & 1.0 & 13 & $<1.0$ & 1.4 & 2.8 & 3.5 & 53.5 \\
\hline \multicolumn{9}{|l|}{ Pesticides ( $\mu \mathrm{g} / \mathrm{L})$} \\
\hline 2,6-Diethylaniline, dissolved & 15 & .006 & 0 & -- & -- & -- & -- & -- \\
\hline $\begin{array}{l}\text { 2-Chloro-4-isopropylamino-6-amino-s-triazine } \\
\text { (CIAT), dissolved }\end{array}$ & 15 & .006 & 15 & E.008 & E.013 & E.029 & E.089 & E.106 \\
\hline Acetochlor, dissolved & 15 & .006 & 0 & -- & -- & -- & -- & -- \\
\hline Alachlor, dissolved & 15 & .005 & 0 & -- & -- & -- & -- & -- \\
\hline alpha-HCH, dissolved & 15 & .005 & 0 & -- & -- & -- & -- & -- \\
\hline Atrazine, dissolved & 15 & .007 & 15 & .082 & .171 & .511 & .883 & 1.920 \\
\hline Azinphos-methyl, dissolved & 15 & .050 & 0 & -- & -- & -- & -- & -- \\
\hline Benfluralin, dissolved & 15 & .010 & 0 & -- & -- & -- & -- & -- \\
\hline Butylate, dissolved & 15 & .004 & 0 & -- & -- & -- & -- & -- \\
\hline Carbaryl, dissolved & 15 & .041 & 1 & $<.041$ & $<.041$ & $<.041$ & $<.041$ & E.072 \\
\hline Carbofuran, dissolved & 15 & .020 & 0 & -- & -- & -- & -- & -- \\
\hline Chlorpyrifos, dissolved & 15 & .005 & 0 & -- & -- & -- & -- & -- \\
\hline
\end{tabular}

Footnote at end of table. 
Appendix 1. Statistical summary of field measurements and physical properties, major cations and anions, nutrients, biological constituents, trace elements, and pesticides at Lake Houston, site AC, February 2000-September 2004—Continued.

\begin{tabular}{|c|c|c|c|c|c|c|c|c|}
\hline \multirow[b]{2}{*}{ Constituent } & \multirow{2}{*}{$\begin{array}{l}\text { Num- } \\
\text { ber of } \\
\text { sam- } \\
\text { ples }\end{array}$} & \multirow{2}{*}{$\begin{array}{c}\text { Mini- } \\
\text { mum } \\
\text { report- } \\
\text { ing } \\
\text { level }\end{array}$} & \multirow{2}{*}{$\begin{array}{l}\text { Number of } \\
\text { detections } \\
\geq \text { reporting } \\
\quad \text { level }\end{array}$} & \multicolumn{5}{|c|}{ Concentration } \\
\hline & & & & $\begin{array}{l}\text { Mini- } \\
\text { mum }\end{array}$ & $\begin{array}{c}25 \text { th } \\
\text { per- } \\
\text { centile }\end{array}$ & Median & $\begin{array}{c}\text { 75th } \\
\text { per- } \\
\text { centile }\end{array}$ & $\begin{array}{l}\text { Maxi- } \\
\text { mum }\end{array}$ \\
\hline \multicolumn{9}{|c|}{ Pesticides ( $\mu \mathrm{g} / \mathrm{L})$ —Continued } \\
\hline cis-Permethrin, dissolved & 15 & 0.006 & 0 & -- & -- & -- & -- & -- \\
\hline Cyanazine, dissolved & 15 & .018 & 0 & -- & -- & -- & -- & -- \\
\hline Dacthal (DCPA), dissolved & 15 & .003 & 0 & -- & -- & -- & -- & -- \\
\hline Desulfinyl fipronil, dissolved & 6 & .012 & 0 & -- & -- & -- & -- & -- \\
\hline Diazinon, dissolved & 15 & .010 & 13 & $<0.010$ & 0.016 & 0.020 & 0.064 & 0.179 \\
\hline Dieldrin, dissolved & 15 & .009 & 0 & -- & -- & -- & -- & -- \\
\hline Disulfoton, dissolved & 15 & .020 & 0 & -- & -- & -- & -- & -- \\
\hline EPTC, dissolved & 15 & .004 & 0 & -- & -- & -- & -- & -- \\
\hline Ethalfluralin, dissolved & 15 & .009 & 0 & -- & -- & -- & -- & -- \\
\hline Ethopropos, dissolved & 15 & .005 & 0 & -- & -- & -- & -- & -- \\
\hline Desulfinylfipronil amide, dissolved & 6 & .029 & 0 & -- & -- & -- & -- & -- \\
\hline Fipronil sulfide, dissolved & 6 & .013 & 0 & -- & -- & -- & -- & -- \\
\hline Fipronil sulfone, dissolved & 6 & .024 & 0 & -- & -- & -- & -- & -- \\
\hline Fipronil, dissolved & 6 & .016 & 0 & -- & -- & -- & -- & -- \\
\hline Fonofos, dissolved & 15 & .003 & 0 & -- & -- & -- & -- & -- \\
\hline Lindane, dissolved & 15 & .004 & 0 & -- & -- & -- & -- & -- \\
\hline Linuron, dissolved & 15 & .035 & 0 & -- & -- & -- & -- & -- \\
\hline Malathion, dissolved & 15 & .027 & 0 & -- & -- & -- & -- & -- \\
\hline Methyl parathion, dissolved & 15 & .015 & 0 & -- & -- & -- & -- & -- \\
\hline Metolachlor, dissolved & 15 & .013 & 5 & $<.013$ & $<.013$ & $<.013$ & .020 & .054 \\
\hline Metribuzin, dissolved & 15 & .006 & 0 & -- & -- & -- & -- & -- \\
\hline Molinate, dissolved & 15 & .004 & 1 & $<.004$ & $<.004$ & $<.004$ & $<.004$ & .017 \\
\hline Napropamide, dissolved & 15 & .007 & 0 & -- & -- & -- & -- & -- \\
\hline$p, p^{\prime}$-DDE, dissolved & 15 & .006 & 0 & -- & -- & -- & -- & -- \\
\hline Parathion, dissolved & 15 & .010 & 0 & -- & -- & -- & -- & -- \\
\hline Pebulate, dissolved & 15 & .004 & 0 & -- & -- & -- & -- & -- \\
\hline Pendimethalin, dissolved & 15 & .022 & 0 & -- & -- & -- & -- & -- \\
\hline Phorate, dissolved & 15 & .011 & 0 & -- & -- & -- & -- & -- \\
\hline Prometon, dissolved & 14 & .010 & 7 & $<.010$ & $<.010$ & $<.010$ & E.010 & E. 010 \\
\hline Propyzamide, dissolved & 15 & .004 & 6 & $<.004$ & $<.004$ & $<.004$ & .011 & .020 \\
\hline Propachlor, dissolved & 15 & .025 & 0 & -- & -- & -- & -- & -- \\
\hline Propanil, dissolved & 15 & .011 & 0 & -- & -- & -- & -- & -- \\
\hline Propargite, dissolved & 15 & .020 & 0 & -- & -- & -- & -- & -- \\
\hline Simazine, dissolved & 14 & .005 & 13 & $<.005$ & .030 & .043 & .131 & .211 \\
\hline Tebuthiuron, dissolved & 15 & .020 & 4 & $<.020$ & $<.020$ & $<.020$ & .040 & .080 \\
\hline Terbacil, dissolved & 15 & .034 & 0 & -- & -- & -- & -- & -- \\
\hline Terbufos, dissolved & 15 & .020 & 0 & -- & -- & -- & -- & -- \\
\hline Thiobencarb, dissolved & 15 & .010 & 0 & -- & -- & -- & -- & -- \\
\hline Tri-allate, dissolved & 15 & .002 & 0 & -- & -- & -- & -- & -- \\
\hline Trifluralin, dissolved & 15 & .009 & 0 & -- & -- & -- & -- & -- \\
\hline
\end{tabular}

${ }^{1}$ Nitrite + nitrate nitrogen plus ammonia + organic nitrogen. 
Appendix 2. Statistical summary of field measurements and physical properties, major cations and anions, nutrients, biological constituents, trace elements, and pesticides at Lake Houston, site EC, February 2000-September 2004.

[ $\geq$, equal to or greater than; $\mu \mathrm{S} / \mathrm{cm}$, microsiemens per centimeter at 25 degrees Celsius; ${ }^{\circ} \mathrm{C}$, degrees Celsius; mg/L, milligrams per liter; <, less than; m, meters; NTU, nephelometric turbidity units; $\mathrm{UV}$, ultraviolet; $\mathrm{cm}$, centimeters; $\mathrm{CaCO}_{3}$, calcium carbonate; --, not applicable or not computed; cols./100 mL, colonies per 100 milliliters, E, estimated; $\mu \mathrm{g} / \mathrm{L}$, micrograms per liter]

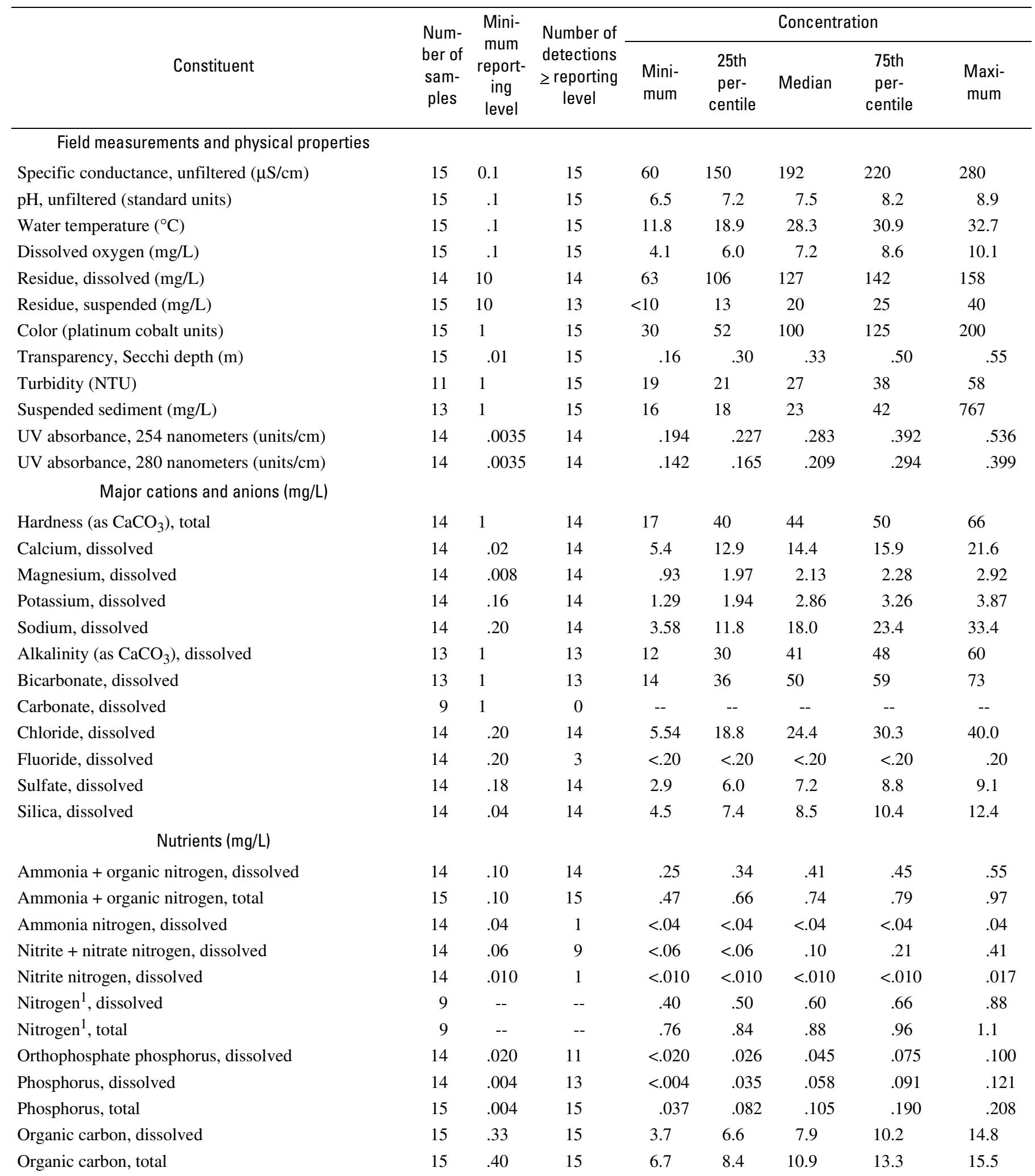

Footnote at end of table. 
Appendix 2. Statistical summary of field measurements and physical properties, major cations and anions, nutrients, biological constituents, trace elements, and pesticides at Lake Houston, site EC, February 2000-September 2004-Continued.

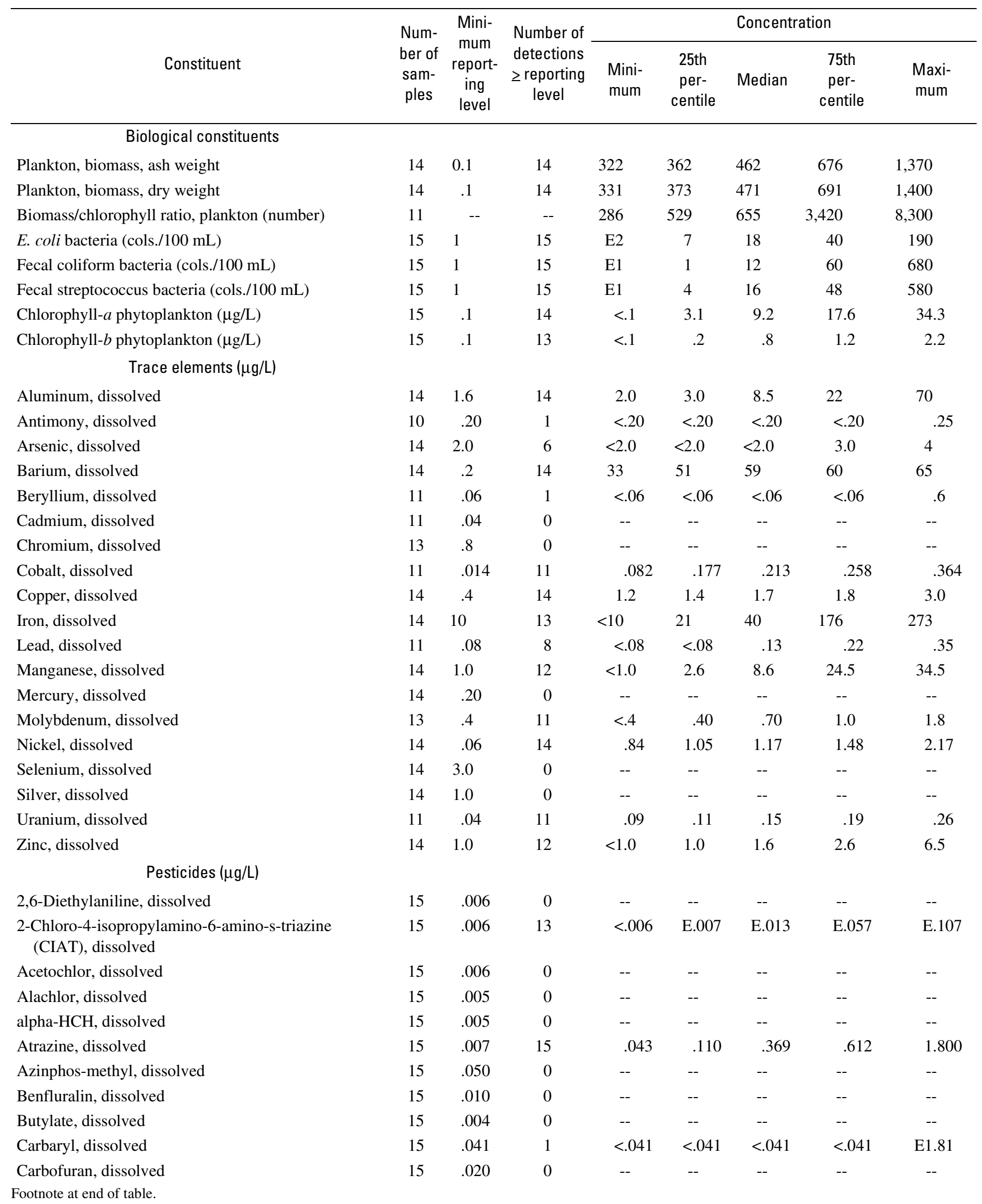


Appendix 2. Statistical summary of field measurements and physical properties, major cations and anions, nutrients, biological constituents, trace elements, and pesticides at Lake Houston, site EC, February 2000-September 2004—Continued.

\begin{tabular}{|c|c|c|c|c|c|c|c|c|}
\hline \multirow[b]{2}{*}{ Constituent } & \multirow{2}{*}{$\begin{array}{l}\text { Num- } \\
\text { ber of } \\
\text { sam- } \\
\text { ples }\end{array}$} & \multirow{2}{*}{$\begin{array}{l}\text { Mini- } \\
\text { mum } \\
\text { report- } \\
\text { ing } \\
\text { level }\end{array}$} & \multirow{2}{*}{$\begin{array}{c}\text { Number of } \\
\text { detections } \\
\geq \text { reporting } \\
\quad \text { level }\end{array}$} & \multicolumn{5}{|c|}{ Concentration } \\
\hline & & & & $\begin{array}{l}\text { Mini- } \\
\text { mum }\end{array}$ & $\begin{array}{c}25 \text { th } \\
\text { per- } \\
\text { centile }\end{array}$ & Median & $\begin{array}{c}75 \text { th } \\
\text { per- } \\
\text { centile }\end{array}$ & $\begin{array}{l}\text { Maxi- } \\
\text { mum }\end{array}$ \\
\hline \multicolumn{9}{|c|}{ Pesticides ( $\mu \mathrm{g} / \mathrm{L}$ )—Continued } \\
\hline Chlorpyrifos, dissolved & 15 & 0.005 & 0 & -- & -- & -- & -- & -- \\
\hline cis-Permethrin, dissolved & 15 & .006 & 0 & -- & -- & -- & -- & -- \\
\hline Cyanazine, dissolved & 15 & .018 & 0 & -- & -- & -- & -- & -- \\
\hline Dacthal (DCPA), dissolved & 15 & .003 & 0 & -- & -- & -- & -- & -- \\
\hline Desulfinyl fipronil, dissolved & 6 & .012 & 0 & -- & -- & -- & -- & -- \\
\hline Diazinon, dissolved & 15 & .010 & 11 & $<0.010$ & $<0.010$ & 0.020 & 0.039 & 0.181 \\
\hline Dieldrin, dissolved & 15 & .009 & 0 & -- & -- & -- & -- & -- \\
\hline Disulfoton, dissolved & 15 & .020 & 0 & -- & -- & -- & -- & -- \\
\hline EPTC, dissolved & 15 & .004 & 0 & -- & -- & -- & -- & -- \\
\hline Ethalfluralin, dissolved & 15 & .009 & 0 & -- & -- & -- & -- & -- \\
\hline Ethopropos, dissolved & 15 & .005 & 0 & -- & -- & -- & -- & -- \\
\hline Desulfinylfipronil amide, dissolved & 6 & .029 & 0 & -- & -- & -- & -- & -- \\
\hline Fipronil sulfide, dissolved & 6 & .013 & 0 & -- & -- & -- & -- & -- \\
\hline Fipronil sulfone, dissolved & 6 & .024 & 0 & -- & -- & -- & -- & -- \\
\hline Fipronil, dissolved & 6 & .016 & 0 & -- & -- & -- & -- & -- \\
\hline Fonofos, dissolved & 15 & .003 & 0 & -- & -- & -- & -- & -- \\
\hline Lindane, dissolved & 15 & .004 & 0 & -- & -- & -- & -- & -- \\
\hline Linuron, dissolved & 15 & .035 & 0 & -- & -- & -- & -- & -- \\
\hline Malathion, dissolved & 15 & .027 & 0 & -- & -- & -- & -- & -- \\
\hline Methyl parathion, dissolved & 15 & .015 & 0 & -- & -- & -- & -- & -- \\
\hline Metolachlor, dissolved & 15 & .013 & 4 & $<.013$ & $<.013$ & $<.013$ & .014 & .029 \\
\hline Metribuzin, dissolved & 15 & .006 & 0 & -- & -- & -- & -- & -- \\
\hline Molinate, dissolved & 15 & .004 & 1 & $<.004$ & $<.004$ & $<.004$ & $<.004$ & .017 \\
\hline Napropamide, dissolved & 15 & .007 & 0 & -- & -- & -- & -- & -- \\
\hline$p, p^{\prime}-\mathrm{DDE}$, dissolved & 15 & .006 & 0 & -- & -- & -- & -- & -- \\
\hline Parathion, dissolved & 15 & .010 & 0 & -- & -- & -- & -- & -- \\
\hline Pebulate, dissolved & 15 & .004 & 0 & -- & -- & -- & -- & -- \\
\hline Pendimethalin, dissolved & 15 & .022 & 0 & -- & -- & -- & -- & -- \\
\hline Phorate, dissolved & 15 & .011 & 0 & -- & -- & -- & -- & -- \\
\hline Prometon, dissolved & 13 & .010 & 7 & $<.010$ & $<.010$ & E. 010 & E. 010 & E. 010 \\
\hline Propyzamide, dissolved & 13 & .004 & 3 & $<.004$ & $<.004$ & $<.004$ & $<.004$ & .012 \\
\hline Propachlor, dissolved & 15 & .025 & 0 & -- & -- & -- & -- & -- \\
\hline Propanil, dissolved & 15 & .011 & 0 & -- & -- & -- & -- & -- \\
\hline Propargite, dissolved & 15 & .020 & 0 & -- & -- & -- & -- & -- \\
\hline Simazine, dissolved & 15 & .009 & 13 & $<.009$ & .010 & .025 & .058 & .172 \\
\hline Tebuthiuron, dissolved & 15 & .020 & 4 & $<.020$ & $<.020$ & $<.020$ & .020 & .070 \\
\hline Terbacil, dissolved & 15 & .034 & 0 & -- & -- & -- & -- & -- \\
\hline Terbufos, dissolved & 15 & .020 & 0 & -- & -- & -- & -- & -- \\
\hline Thiobencarb, dissolved & 15 & .010 & 0 & -- & -- & -- & -- & -- \\
\hline Tri-allate, dissolved & 15 & .002 & 0 & -- & -- & -- & -- & -- \\
\hline Trifluralin, dissolved & 15 & .009 & 0 & -- & -- & -- & -- & -- \\
\hline
\end{tabular}

\footnotetext{
${ }^{1}$ Nitrite + nitrate nitrogen plus ammonia + organic nitrogen.
} 
Appendix 3. Statistical summary of field measurements and physical properties, major cations and anions, nutrients, biological constituents, trace elements, and pesticides at Lake Houston, site FC, February 2000-September 2004.

[ $\geq$, equal to or greater than; $\mu \mathrm{S} / \mathrm{cm}$, microsiemens per centimeter at 25 degrees Celsius; ${ }^{\circ} \mathrm{C}$, degrees Celsius; mg/L, milligrams per liter; m, meters; NTU, nephelometric turbidity units; $\mathrm{UV}$, ultraviolet; $\mathrm{cm}$, centimeters; $\mathrm{CaCO}_{3}$, calcium carbonate; <, less than; --, not applicable or not computed; cols./100 mL, colonies per 100 milliliters, E, estimated; $\mu \mathrm{g} / \mathrm{L}$, micrograms per liter]

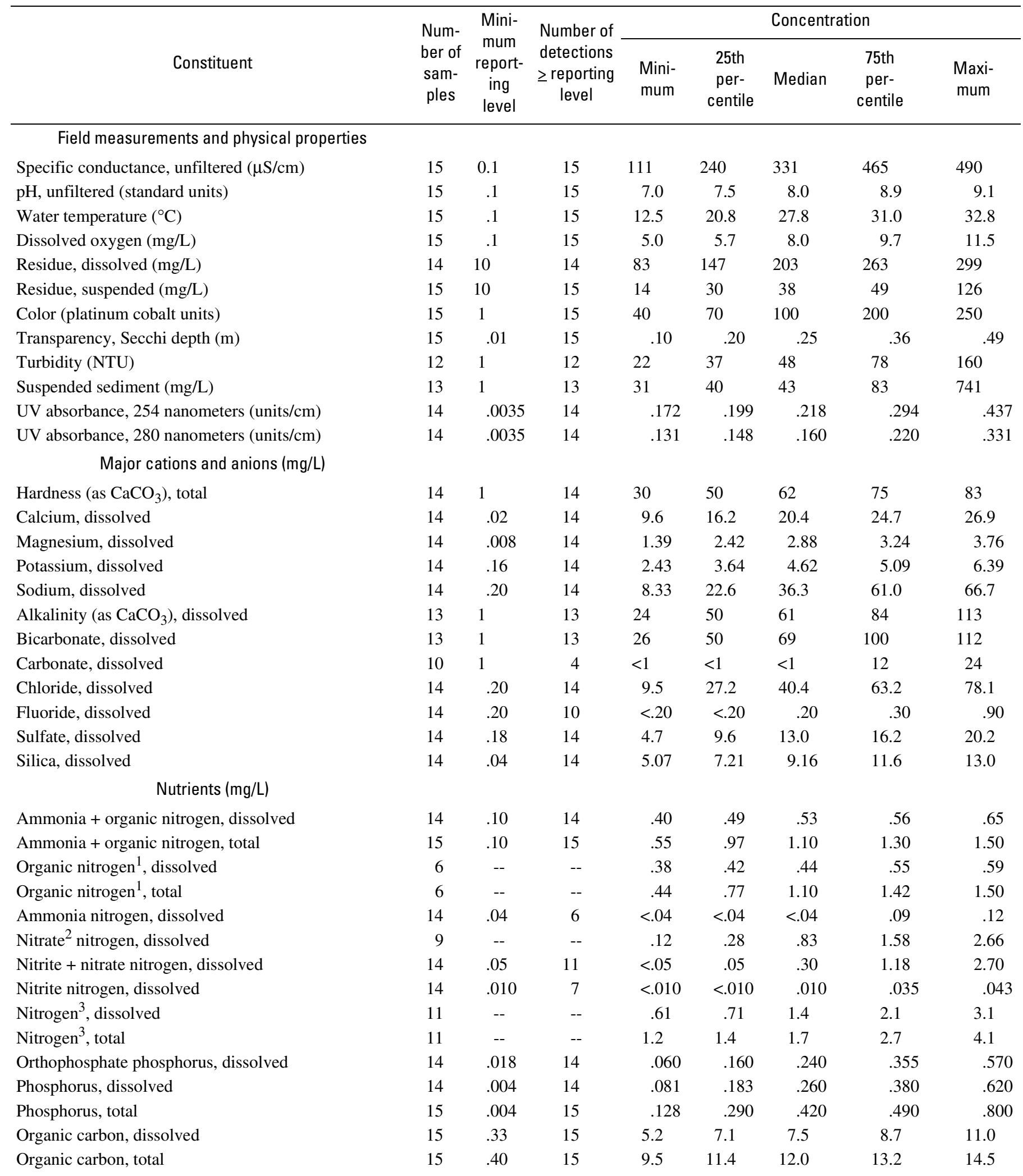

Footnote at end of table. 
Appendix 3. Statistical summary of field measurements and physical properties, major cations and anions, nutrients, biological constituents, trace elements, and pesticides at Lake Houston, site FC, February 2000-September 2004-Continued.

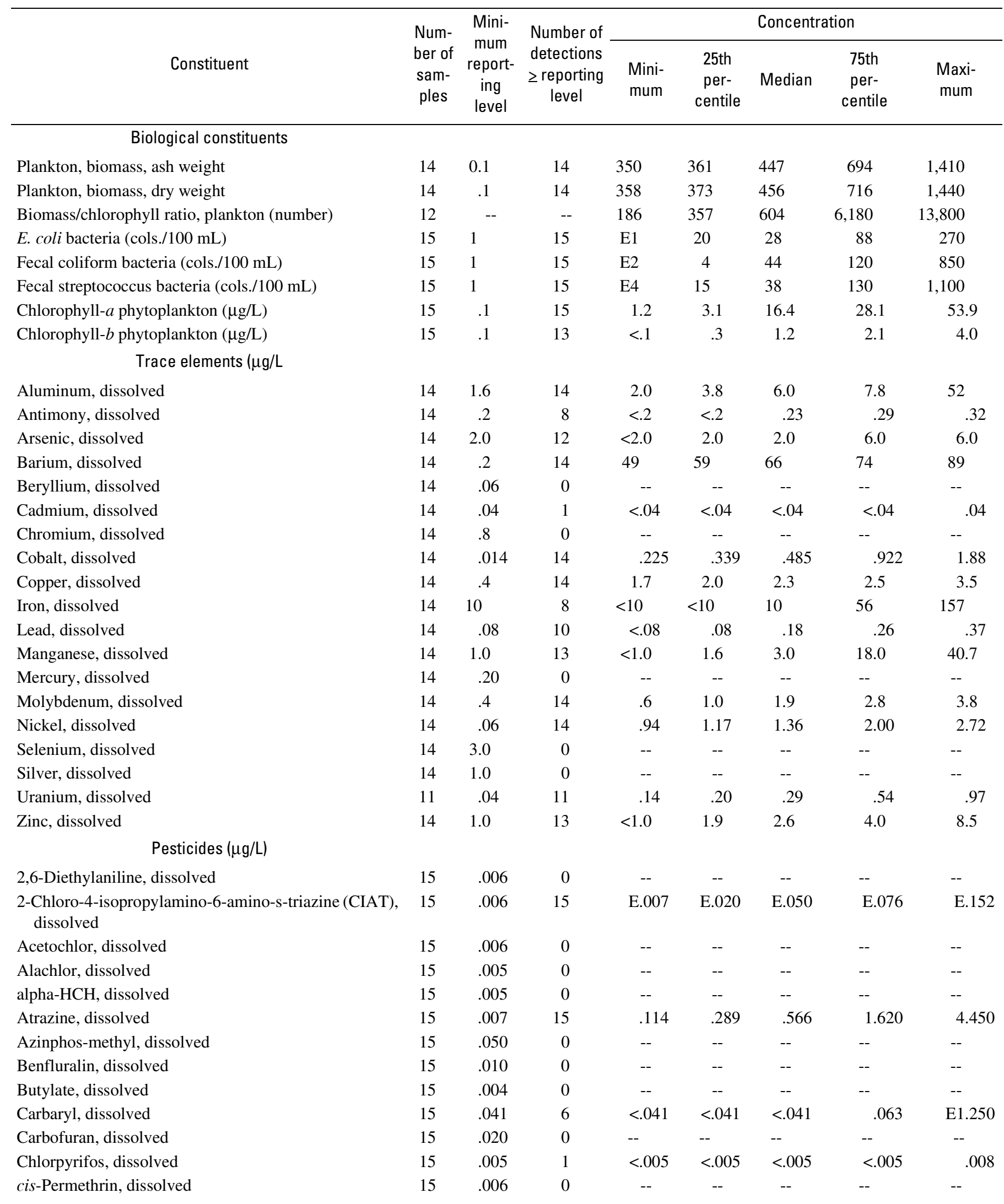

Footnote at end of table. 
Appendix 3. Statistical summary of field measurements and physical properties, major cations and anions, nutrients, biological constituents, trace elements, and pesticides at Lake Houston, site FC, February 2000-September 2004-Continued.

\begin{tabular}{|c|c|c|c|c|c|c|c|c|}
\hline \multirow[b]{2}{*}{ Constituent } & \multirow{2}{*}{$\begin{array}{l}\text { Num- } \\
\text { ber of } \\
\text { sam- } \\
\text { ples }\end{array}$} & \multirow{2}{*}{$\begin{array}{l}\text { Mini- } \\
\text { mum } \\
\text { report- } \\
\text { ing } \\
\text { level }\end{array}$} & \multirow{2}{*}{$\begin{array}{c}\text { Number of } \\
\text { detections } \\
\geq \begin{array}{c}\text { reporting } \\
\text { level }\end{array}\end{array}$} & \multicolumn{5}{|c|}{ Concentration } \\
\hline & & & & $\begin{array}{l}\text { Mini- } \\
\text { mum }\end{array}$ & $\begin{array}{c}25 \text { th } \\
\text { per- } \\
\text { centile }\end{array}$ & Median & $\begin{array}{c}\text { 75th } \\
\text { per- } \\
\text { centile }\end{array}$ & $\begin{array}{l}\text { Maxi- } \\
\text { mum }\end{array}$ \\
\hline \multicolumn{9}{|l|}{ Pesticides ( $\mu \mathrm{g} / \mathrm{L})$} \\
\hline Cyanazine, dissolved & 15 & 0.018 & 0 & -- & -- & -- & -- & -- \\
\hline Dacthal (DCPA), dissolved & 15 & .003 & 0 & -- & -- & -- & -- & -- \\
\hline Desulfinyl fipronil, dissolved & 6 & .012 & 0 & -- & -- & -- & -- & -- \\
\hline Diazinon, dissolved & 15 & .015 & 14 & $<0.015$ & 0.027 & 0.034 & 0.123 & 0.616 \\
\hline Dieldrin, dissolved & 15 & .009 & 0 & -- & -- & -- & -- & -- \\
\hline Disulfoton, dissolved & 15 & .020 & 0 & -- & -- & -- & -- & -- \\
\hline EPTC, dissolved & $15^{\prime}$ & .004 & 0 & -- & -- & -- & -- & -- \\
\hline Ethalfluralin, dissolved & 15 & .009 & 0 & -- & -- & -- & -- & -- \\
\hline Ethopropos, dissolved & 15 & .005 & 0 & -- & -- & -- & -- & -- \\
\hline Desulfinylfipronil amide, dissolved & 6 & .029 & 0 & -- & -- & -- & -- & -- \\
\hline Fipronil sulfide, dissolved & 6 & .013 & 0 & -- & -- & -- & -- & -- \\
\hline Fipronil sulfone, dissolved & 6 & .024 & 0 & -- & -- & -- & -- & -- \\
\hline Fipronil, dissolved & 6 & .016 & 3 & $<.016$ & $<.016$ & $<.016$ & E.019 & E.019 \\
\hline Fonofos, dissolved & 15 & .003 & 0 & -- & -- & -- & -- & -- \\
\hline Lindane, dissolved & 15 & .004 & 0 & -- & -- & -- & -- & -- \\
\hline Linuron, dissolved & 15 & .035 & 0 & -- & -- & -- & -- & -- \\
\hline Malathion, dissolved & 15 & .027 & 0 & -- & -- & -- & -- & -- \\
\hline Methyl parathion, dissolved & 15 & .015 & 0 & -- & -- & -- & -- & -- \\
\hline Metolachlor, dissolved & 15 & .013 & 4 & $<.013$ & $<.013$ & $<.013$ & .013 & .057 \\
\hline Metribuzin, dissolved & 15 & .006 & 0 & -- & -- & -- & -- & -- \\
\hline Molinate, dissolved & 15 & .004 & 1 & $<.004$ & $<.004$ & $<.004$ & $<.004$ & .015 \\
\hline Napropamide, dissolved & 15 & .007 & 0 & -- & -- & -- & -- & -- \\
\hline$p, p^{\prime}$-DDE, dissolved & 15 & .006 & 0 & -- & -- & -- & -- & -- \\
\hline Parathion, dissolved & 15 & .010 & 0 & -- & -- & -- & -- & -- \\
\hline Pebulate, dissolved & 15 & .004 & 0 & -- & -- & -- & -- & -- \\
\hline Pendimethalin, dissolved & 15 & .022 & 0 & -- & -- & -- & -- & -- \\
\hline Phorate, dissolved & 15 & .011 & 0 & -- & -- & -- & -- & -- \\
\hline Prometon, dissolved & 14 & .010 & 9 & $<.010$ & $<.010$ & .010 & .020 & .050 \\
\hline Propyzamide, dissolved & 15 & .018 & 3 & $<.018$ & $<.018$ & $<.018$ & $<.018$ & .045 \\
\hline Propachlor, dissolved & 15 & .025 & 0 & -- & -- & -- & -- & -- \\
\hline Propanil, dissolved & 15 & .011 & 0 & -- & -- & -- & -- & -- \\
\hline Propargite, dissolved & 15 & .020 & 0 & -- & -- & -- & -- & -- \\
\hline Simazine, dissolved & 15 & .005 & 15 & E.008 & .022 & .037 & .187 & 1.210 \\
\hline Tebuthiuron, dissolved & 15 & .020 & 6 & $<.020$ & $<.020$ & $<.020$ & .040 & .120 \\
\hline Terbacil, dissolved & 15 & .034 & 0 & -- & -- & -- & -- & -- \\
\hline Terbufos, dissolved & 15 & .020 & 0 & -- & -- & -- & -- & -- \\
\hline Thiobencarb, dissolved & 15 & .010 & 0 & -- & -- & -- & -- & -- \\
\hline Tri-allate, dissolved & 15 & .002 & 0 & -- & -- & -- & -- & -- \\
\hline Trifluralin, dissolved & 15 & .009 & 0 & -- & -- & -- & -- & -- \\
\hline
\end{tabular}

\footnotetext{
${ }^{1}$ Ammonia + organic nitrogen minus ammonia nitrogen.

${ }^{2}$ Nitrite + nitrate nitrogen minus dissolved nitrite nitrogen.

${ }^{3}$ Nitrite + nitrate nitrogen plus ammonia + organic nitrogen.
} 
Appendix 4. Statistical summary of field measurements and physical properties, major cations and anions, nutrients, biological constituents, trace elements, and pesticides in samples collected from low flows at Cypress Creek, June 2000-September 2004.

[ $\geq$, equal to or greater than; $\mu \mathrm{S} / \mathrm{cm}$, microsiemens per centimeter at 25 degrees Celsius; ${ }^{\circ} \mathrm{C}$, degrees Celsius; $\mathrm{mg} / \mathrm{L}$, milligrams per liter; NTU, nephelometric turbidity units; $\mathrm{UV}$, ultraviolet; $\mathrm{cm}$, centimeters; $\mathrm{CaCO}_{3}$, calcium carbonate; <, less than; --, not applicable or not computed; cols./100 mL, colonies per 100 milliliters, E, estimated; >, greater than; $\mu \mathrm{g} / \mathrm{L}$, micrograms per liter]

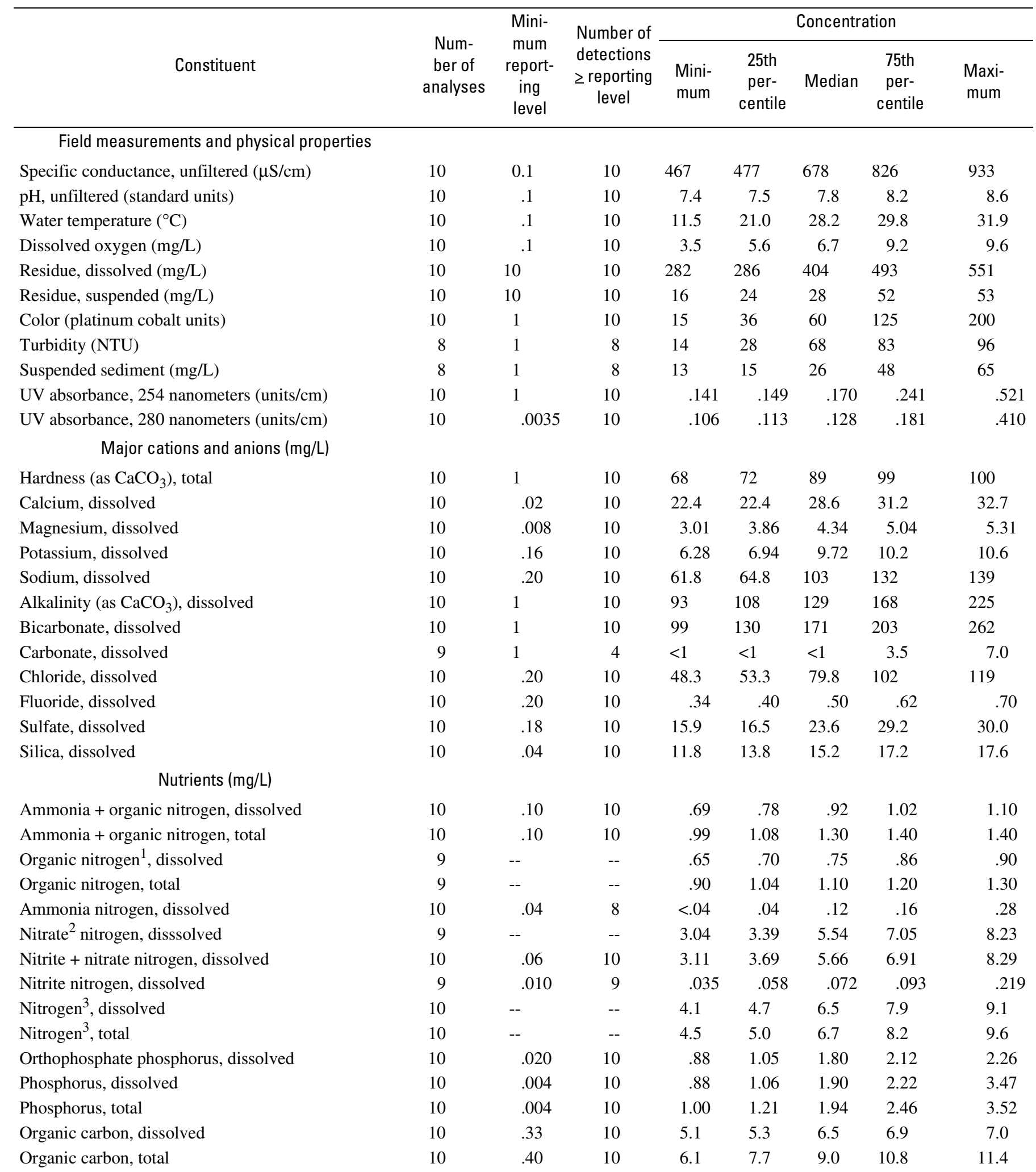

Footnote at end of table. 
Appendix 4. Statistical summary of field measurements and physical properties, major cations and anions, nutrients, biological constituents, trace elements, and pesticides in samples collected from low flows at Cypress Creek, June 2000-September 2004-Continued.

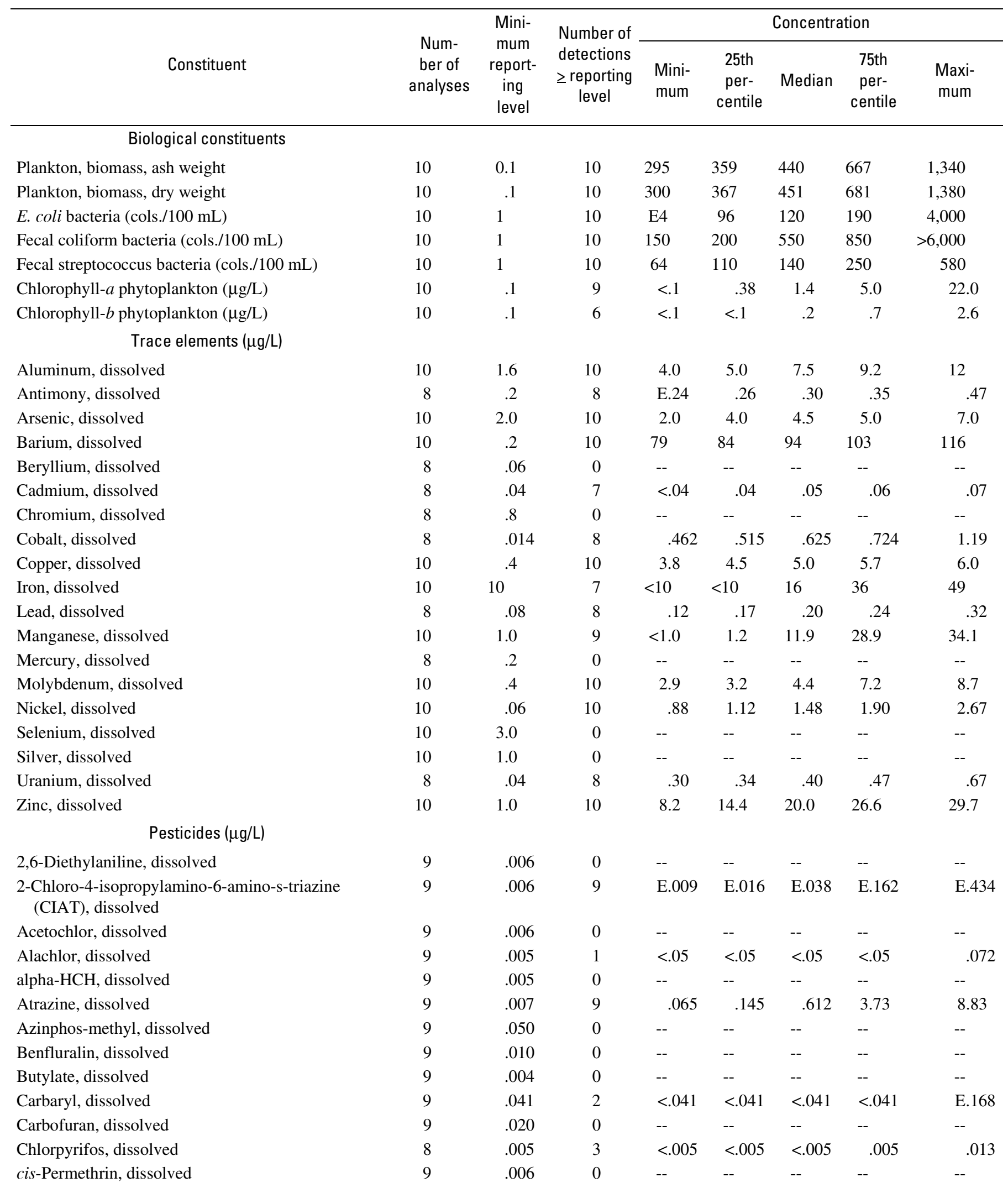

Footnote at end of table. 
Appendix 4. Statistical summary of field measurements and physical properties, major cations and anions, nutrients, biological constituents, trace elements, and pesticides in samples collected from low flows at Cypress Creek, June 2000-September 2004-Continued.

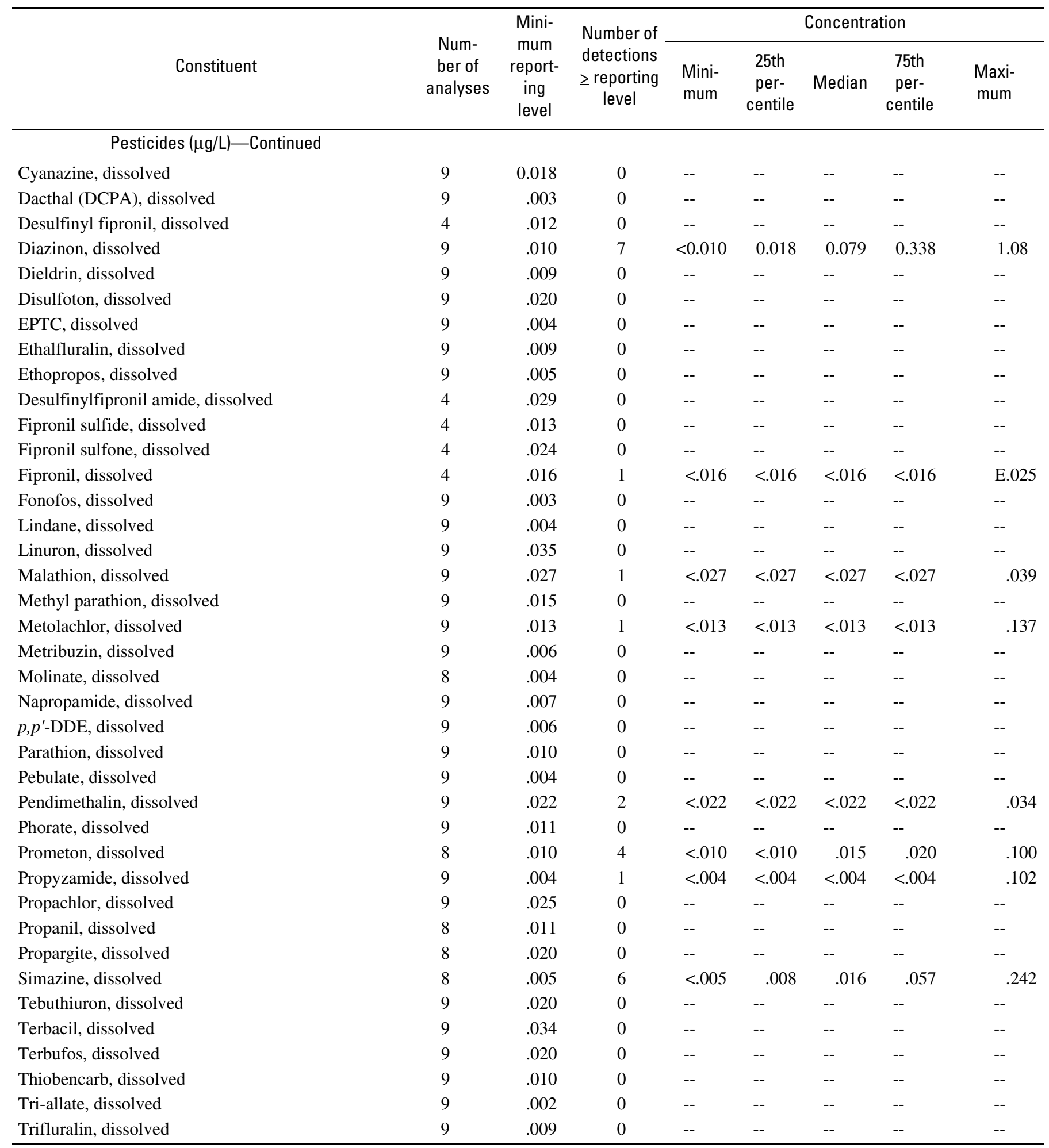

${ }^{1}$ Ammonia + organic nitrogen minus ammonia nitrogen.

${ }^{2}$ Nitrite + nitrate nitrogen minus dissolved nitrite nitrogen.

${ }^{3}$ Nitrite + nitrate nitrogen plus ammonia + organic nitrogen. 
Appendix 5. Statistical summary of field measurements and physical properties, major cations and anions, nutrients, biological constituents, trace elements, and pesticides in samples collected from high flows at Cypress Creek, April 2002-November 2004.

$\left[\geq\right.$, equal to or greater than; $\mu \mathrm{S} / \mathrm{cm}$, microsiemens per centimeter at 25 degrees Celsius; ${ }^{\circ} \mathrm{C}$, degrees Celsius; mg/L, milligrams per liter; $\mathrm{NTU}$, nephelometric turbidity units; UV, ultraviolet; $\mathrm{cm}$, centimeters; $\mathrm{CaCO}_{3}$, calcium carbonate; --, not applicable or not computed; <, less than; cols./100 mL, colonies per 100 milliliters, $\mu \mathrm{g} / \mathrm{L}$, micrograms per liter; E, estimated]

\begin{tabular}{|c|c|c|c|c|c|c|c|c|}
\hline Constituent & $\begin{array}{c}\text { Num- } \\
\text { ber of } \\
\text { samples }\end{array}$ & $\begin{array}{l}\text { Mini- } \\
\text { mum } \\
\text { report- } \\
\text { ing } \\
\text { level }\end{array}$ & $\begin{array}{l}\text { Number of } \\
\text { detections } \\
\geq \text { reporting } \\
\quad \text { level }\end{array}$ & \multicolumn{5}{|c|}{ Concentration } \\
\hline \multicolumn{9}{|l|}{ Field measurements and physical properties } \\
\hline Specific conductance, unfiltered $(\mu \mathrm{S} / \mathrm{cm})$ & 8 & 0.1 & 8 & 67.0 & 104 & 160 & 306 & 485 \\
\hline Water temperature $\left({ }^{\circ} \mathrm{C}\right)$ & 8 & .1 & 8 & 15.9 & 19.2 & 22.2 & 24.6 & 25.1 \\
\hline Dissolved oxygen (mg/L) & 7 & .1 & 7 & 6.0 & 6.4 & 7.1 & 8.8 & 8.9 \\
\hline Residue, dissolved (mg/L) & 8 & 10 & 8 & 54 & 73 & 87 & 146 & 167 \\
\hline Residue, suspended (mg/L) & 8 & 10 & 8 & 88 & 126 & 237 & 376 & 540 \\
\hline Color (platinum cobalt units) & 8 & 1 & 8 & 88 & 119 & 200 & 250 & 250 \\
\hline UV absorbance, 280 nanometers (units/cm) & 8 & .0035 & 8 & .182 & .199 & .232 & .278 & .552 \\
\hline \multicolumn{9}{|l|}{ Major cations and anions (mg/L) } \\
\hline Hardness (as $\mathrm{CaCO}_{3}$ ), total & 8 & 1 & 8 & 17 & 23 & 24 & 39 & 48 \\
\hline Calcium, dissolved & 8 & .02 & 8 & 5.11 & 7.22 & 7.90 & 13.0 & 15.6 \\
\hline Magnesium, dissolved & 8 & .008 & 8 & 1.07 & 1.10 & 1.32 & 1.74 & 2.08 \\
\hline Potassium, dissolved & 8 & .16 & 8 & 2.57 & 3.01 & 3.84 & 5.44 & 5.81 \\
\hline Sodium, dissolved & 8 & .20 & 8 & 3.20 & 10.6 & 12.0 & 24.1 & 39.8 \\
\hline Alkalinity (as $\mathrm{CaCO}_{3}$ ), dissolved & 7 & 1 & 7 & 27 & 32 & 36 & 61 & 67 \\
\hline Bicarbonate, dissolved & 7 & 1 & 7 & 33 & 39 & 44 & 74 & 82 \\
\hline Carbonate, dissolved & 7 & 1 & 0 & -- & -- & -- & -- & -- \\
\hline Ammonia + organic nitrogen, total & 8 & .10 & 8 & 1.5 & 1.8 & 2.2 & 5.4 & 7.1 \\
\hline Organic nitrogen ${ }^{1}$, dissolved & 5 & -- & -- & .51 & .54 & 1.1 & 2.9 & 3.8 \\
\hline Organic nitrogen ${ }^{1}$, total & 5 & -- & -- & 1.4 & 1.9 & 2.3 & 5.8 & 6.8 \\
\hline Ammonia nitrogen, dissolved & 8 & .04 & 7 & $<.04$ & .04 & .04 & .24 & .29 \\
\hline Nitrate $^{2}$ nitrogen, disssolved & 7 & -- & -- & .16 & .18 & .54 & 1.12 & 2.10 \\
\hline Nitrite + nitrate nitrogen, dissolved & 8 & .06 & 8 & .11 & .22 & .54 & 1.02 & 2.13 \\
\hline Nitrite nitrogen, dissolved & 8 & .010 & 7 & $<.01$ & .012 & .023 & .047 & .070 \\
\hline Nitrogen $^{3}$, dissolved & 8 & -- & -- & 1.1 & 1.3 & 2.4 & 3.3 & 4.4 \\
\hline Nitrogen $^{3}$, total & 8 & -- & -- & 2.0 & 2.6 & 3.3 & 5.7 & 7.3 \\
\hline Orthophosphate phosphorus, dissolved & 8 & .020 & 7 & $<.02$ & .07 & .20 & .32 & .70 \\
\hline Phosphorus, dissolved & 8 & .004 & 8 & .10 & .20 & .25 & .39 & .72 \\
\hline Phosphorus, total & 8 & .004 & 8 & .26 & .46 & .62 & .73 & .98 \\
\hline Organic carbon, dissolved & 8 & .33 & 8 & 5.9 & 7.4 & 13.4 & 22.5 & 32.3 \\
\hline Organic carbon, total & 8 & .40 & 8 & 14.3 & 18.9 & 22.6 & 34.5 & 36.3 \\
\hline
\end{tabular}

Footnote at end of table. 
Appendix 5. Statistical summary of field measurements and physical properties, major cations and anions, nutrients, biological constituents, trace elements, and pesticides in samples collected from high flows at Cypress Creek, April 2002-November 2004-Continued.

\begin{tabular}{|c|c|c|c|c|c|c|c|c|}
\hline Constituent & $\begin{array}{c}\text { Num- } \\
\text { ber of } \\
\text { samples }\end{array}$ & $\begin{array}{l}\text { Mini- } \\
\text { mum } \\
\text { report- } \\
\text { ing } \\
\text { level }\end{array}$ & $\begin{array}{l}\text { Number of } \\
\text { detections } \\
\geq \text { reporting } \\
\quad \text { level }\end{array}$ & \multicolumn{5}{|c|}{ Concentration } \\
\hline \multicolumn{9}{|l|}{ Biological constituents } \\
\hline Plankton, biomass, ash weight & 8 & 0.1 & 8 & 759 & 826 & 1,130 & 1,690 & 1,870 \\
\hline E. coli bacteria (cols./100 mL) & 6 & 1 & 6 & 150 & 1,700 & 3,100 & 5,900 & 7,900 \\
\hline Fecal coliform bacteria (cols./100 mL) & 6 & 1 & 6 & 210 & 2,100 & 4,900 & 5,800 & 6,000 \\
\hline Fecal streptococcus bacteria (cols./100 mL) & 6 & 1 & 6 & 980 & 1,700 & 4,800 & 6,500 & 8,200 \\
\hline Chlorophyll- $a$ phytoplankton $(\mu \mathrm{g} / \mathrm{L})$ & 7 & .1 & 6 & $<.1$ & 1.1 & 2.8 & 8.7 & 9.9 \\
\hline Chlorophyll- $b$ phytoplankton $(\mu \mathrm{g} / \mathrm{L})$ & 7 & .1 & 4 & $<.1$ & $<.1$ & .1 & .8 & E1.0 \\
\hline Arsenic, dissolved & 8 & 2.0 & 8 & 2.0 & 2.2 & 4.0 & 5.0 & 6.0 \\
\hline Barium, dissolved & 8 & .2 & 8 & 25 & 32 & 38 & 48 & 161 \\
\hline Beryllium, dissolved & 8 & .06 & 0 & -- & -- & -- & -- & -- \\
\hline Cadmium, dissolved & 8 & .04 & 5 & $<.04$ & $<.04$ & .04 & .09 & .11 \\
\hline Chromium, dissolved & 8 & .8 & 1 & $<.8$ & $<.8$ & $<.8$ & $<.8$ & .9 \\
\hline Cobalt, dissolved & 8 & .014 & 8 & .085 & .104 & .169 & .237 & .516 \\
\hline Copper, dissolved & 8 & .4 & 8 & 2.7 & 3.0 & 3.6 & 4.6 & 5.0 \\
\hline Iron, dissolved & 8 & 10 & 8 & 41 & 65 & 76 & 96 & 179 \\
\hline Lead, dissolved & 8 & .08 & 8 & .12 & .14 & .32 & .48 & .55 \\
\hline Manganese, dissolved & 8 & .60 & 8 & .90 & 1.2 & 2.4 & 4.9 & 51.1 \\
\hline Zinc, dissolved & 8 & 1.0 & 8 & 4.1 & 6.7 & 27.6 & 320 & 349 \\
\hline \multicolumn{9}{|l|}{ Pesticides $(\mu \mathrm{g} / \mathrm{L})$} \\
\hline 2,6-Diethylaniline, dissolved & 8 & .006 & 0 & -- & -- & -- & -- & -- \\
\hline $\begin{array}{l}\text { 2-Chloro-4-isopropylamino-6-amino-s-triazine } \\
\text { (CIAT), dissolved }\end{array}$ & 8 & .015 & 7 & $<.015$ & E.020 & E.044 & E.053 & E.266 \\
\hline Acetochlor, dissolved & 8 & .010 & 0 & -- & -- & -- & -- & -- \\
\hline Alachlor, dissolved & 8 & .005 & 1 & $<.005$ & $<.005$ & $<.005$ & $<.005$ & .020 \\
\hline alpha-HCH, dissolved & 8 & .005 & 0 & -- & -- & -- & -- & -- \\
\hline Atrazine, dissolved & 8 & .007 & 8 & .282 & .918 & 1.09 & 1.30 & 21.3 \\
\hline Azinphos-methyl, dissolved & 8 & .050 & 0 & -- & -- & -- & -- & -- \\
\hline Benfluralin, dissolved & 8 & .010 & 0 & -- & -- & -- & -- & -- \\
\hline Butylate, dissolved & 8 & .004 & 0 & -- & -- & -- & -- & -- \\
\hline Carbaryl, dissolved & 8 & .041 & 7 & $<.041$ & E. 153 & E.195 & E.343 & E.655 \\
\hline Carbofuran, dissolved & 8 & .020 & 0 & -- & -- & -- & -- & -- \\
\hline Chlorpyrifos, dissolved & 8 & .005 & 2 & $<.005$ & $<.005$ & $<.005$ & $<.005$ & .055 \\
\hline cis-Permethrin, dissolved & 8 & .006 & 0 & -- & -- & -- & -- & -- \\
\hline
\end{tabular}


Appendix 5. Statistical summary of field measurements and physical properties, major cations and anions, nutrients, biological constituents, trace elements, and pesticides in samples collected from high flows at Cypress Creek, April 2002-November 2004-Continued.

\begin{tabular}{|c|c|c|c|c|c|c|c|c|}
\hline Constituent & $\begin{array}{c}\text { Num- } \\
\text { ber of } \\
\text { samples }\end{array}$ & $\begin{array}{l}\text { Mini- } \\
\text { mum } \\
\text { report- } \\
\text { ing } \\
\text { level }\end{array}$ & $\begin{array}{c}\text { Number of } \\
\text { detections } \\
\geq \begin{array}{c}\text { reporting } \\
\text { level }\end{array}\end{array}$ & \multicolumn{5}{|c|}{ Concentration } \\
\hline \multicolumn{9}{|l|}{ Pesticides ( $\mu \mathrm{g} / \mathrm{L})$} \\
\hline Cyanazine, dissolved & 8 & 0.018 & 0 & -- & -- & -- & -- & -- \\
\hline Desulfinyl fipronil, dissolved & 7 & .004 & 3 & $<0.004$ & $<0.004$ & $<0.004$ & E0.004 & E0.006 \\
\hline Diazinon, dissolved & 8 & .010 & 8 & .024 & .066 & .192 & .242 & 1.17 \\
\hline Dieldrin, dissolved & 8 & .009 & 0 & -- & -- & -- & -- & -- \\
\hline Disulfoton, dissolved & 8 & .020 & 0 & -- & -- & -- & -- & -- \\
\hline EPTC, dissolved & 8 & .004 & 0 & -- & -- & -- & -- & -- \\
\hline Fipronil sulfide, dissolved & 7 & .010 & 0 & -- & -- & -- & -- & -- \\
\hline Fipronil sulfone, dissolved & 7 & .024 & 0 & -- & -- & -- & -- & -- \\
\hline Fipronil, dissolved & 7 & .031 & 3 & $<.031$ & $<.031$ & $<.031$ & .049 & E.070 \\
\hline Fonofos, dissolved & 8 & .003 & 0 & -- & -- & -- & -- & -- \\
\hline Lindane, dissolved & 8 & .004 & 0 & -- & -- & -- & -- & -- \\
\hline Linuron, dissolved & 8 & .035 & 0 & -- & -- & -- & -- & -- \\
\hline Malathion, dissolved & 8 & .027 & 4 & $<.027$ & $<.027$ & $<.027$ & .047 & .072 \\
\hline Methyl parathion, dissolved & 8 & .015 & 0 & -- & -- & -- & -- & -- \\
\hline Metolachlor, dissolved & 8 & .013 & 1 & $<.013$ & $<.013$ & $<.013$ & $<.013$ & .100 \\
\hline Metribuzin, dissolved & 8 & .006 & 0 & -- & -- & -- & -- & -- \\
\hline Prometon, dissolved & 7 & .010 & 4 & $<.010$ & $<.010$ & E.010 & .010 & .020 \\
\hline Propyzamide, dissolved & 8 & .004 & 1 & $<.004$ & $<.004$ & $<.004$ & $<.004$ & .039 \\
\hline Propachlor, dissolved & 8 & .025 & 0 & -- & -- & -- & -- & -- \\
\hline Propanil, dissolved & 8 & .011 & 0 & -- & -- & -- & -- & -- \\
\hline Propargite, dissolved & 8 & .020 & 0 & -- & -- & -- & -- & -- \\
\hline Simazine, dissolved & 8 & .005 & 8 & .009 & .019 & .35 & .59 & 3.27 \\
\hline Tebuthiuron, dissolved & 8 & .020 & 0 & -- & -- & -- & -- & -- \\
\hline Terbacil, dissolved & 8 & .034 & 0 & -- & -- & -- & -- & -- \\
\hline Terbufos, dissolved & 8 & .020 & 0 & -- & -- & -- & -- & -- \\
\hline Thiobencarb, dissolved & 8 & .010 & 0 & -- & -- & -- & -- & -- \\
\hline Tri-allate, dissolved & 8 & .006 & 0 & -- & -- & -- & -- & -- \\
\hline Trifluralin, dissolved & 8 & .009 & 1 & $<.009$ & $<.009$ & $<.009$ & $<.009$ & .015 \\
\hline
\end{tabular}

${ }^{1}$ Ammonia + organic nitrogen minus ammonia nitrogen.

${ }^{2}$ Nitrite + nitrate nitrogen minus dissolved nitrite nitrogen.

${ }^{3}$ Nitrite + nitrate nitrogen plus ammonia + organic nitrogen. 
Appendix 6. Statistical summary of field measurements and physical properties, major cations and anions, nutrients, biological constituents, trace elements, and pesticides in samples collected from low flows at East Fork San Jacinto River, June 2000-September 2004.

[ $\geq$, equal to or greater than; $\mu \mathrm{S} / \mathrm{cm}$, microsiemens per centimeter at 25 degrees Celsius; ${ }^{\circ} \mathrm{C}$, degrees Celsius; $\mathrm{mg} / \mathrm{L}$, milligrams per liter; <, less than; NTU, nephelometric turbidity units; UV, ultraviolet; $\mathrm{cm}$, centimeters; $\mathrm{CaCO}_{3}$, calcium carbonate; --, not applicable or not computed; cols./100 mL, colonies per 100 milliliters, E, estimated; $\mu \mathrm{g} / \mathrm{L}$, micrograms per liter]

\begin{tabular}{|c|c|c|c|c|c|c|c|c|}
\hline \multirow[b]{2}{*}{ Constituent } & \multirow{2}{*}{$\begin{array}{l}\text { Num- } \\
\text { ber of } \\
\text { samples }\end{array}$} & \multirow{2}{*}{$\begin{array}{l}\text { Mini- } \\
\text { mum } \\
\text { report- } \\
\text { ing } \\
\text { level }\end{array}$} & \multirow{2}{*}{$\begin{array}{l}\text { Number of } \\
\text { detections } \\
\geq \text { reporting } \\
\quad \text { level }\end{array}$} & \multicolumn{5}{|c|}{ Concentration } \\
\hline & & & & $\begin{array}{l}\text { Mini- } \\
\text { mum }\end{array}$ & $\begin{array}{c}25 \text { th } \\
\text { per- } \\
\text { centile }\end{array}$ & Median & $\begin{array}{c}\text { 75th } \\
\text { per- } \\
\text { centile }\end{array}$ & $\begin{array}{l}\text { Maxi- } \\
\text { mum }\end{array}$ \\
\hline \multicolumn{9}{|c|}{ Field measurements and physical properties } \\
\hline Specific conductance, unfiltered $(\mu \mathrm{S} / \mathrm{cm})$ & 10 & 0.1 & 10 & 177 & 184 & 186 & 204 & 228 \\
\hline pH, unfiltered (standard units) & 10 & .1 & 10 & 6.7 & 6.8 & 7.0 & 7.2 & 7.5 \\
\hline Water temperature $\left({ }^{\circ} \mathrm{C}\right)$ & 10 & .1 & 10 & 12.5 & 17.4 & 25.4 & 27.1 & 29.3 \\
\hline Dissolved oxygen (mg/L) & 10 & .1 & 10 & 6.6 & 6.8 & 7.7 & 8.7 & 10.2 \\
\hline Residue, dissolved (mg/L) & 10 & 10 & 10 & 105 & 110 & 116 & 122 & 146 \\
\hline Residue, suspended (mg/L) & 10 & 10 & 7 & $<10$ & $<10$ & 14 & 22 & 31 \\
\hline Color (platinum cobalt units) & 10 & 1 & 10 & 25 & 36 & 61 & 75 & 80 \\
\hline Turbidity (NTU) & 8 & .01 & 8 & 8.9 & 14 & 20 & 34 & 46 \\
\hline Suspended sediment (mg/L) & 8 & 1 & 11 & 11 & 14 & 16 & 56 & 69 \\
\hline UV absorbance, 254 nanometers (units/cm) & 10 & 1 & 10 & .087 & .130 & .178 & .272 & .346 \\
\hline UV absorbance, 280 nanometers (units/cm) & 10 & .0035 & 10 & .066 & .100 & .132 & .211 & .258 \\
\hline \multicolumn{9}{|l|}{ Major cations and anions $(\mathrm{mg} / \mathrm{L})$} \\
\hline Hardness (as $\mathrm{CaCO}_{3}$ ), total & 10 & 1 & 10 & 35 & 37 & 46 & 50 & 56 \\
\hline Calcium, dissolved & 10 & .02 & 10 & 10.9 & 12.0 & 15.2 & 16.4 & 18.4 \\
\hline Magnesium, dissolved & 10 & .008 & 10 & 1.81 & 1.83 & 1.99 & 2.18 & 2.41 \\
\hline Potassium, dissolved & 10 & .16 & 10 & 1.29 & 1.48 & 1.54 & 1.83 & 2.36 \\
\hline Sodium, dissolved & 10 & .20 & 10 & 13.6 & 14.6 & 16.2 & 18.6 & 19.4 \\
\hline Alkalinity (as $\mathrm{CaCO}_{3}$ ), dissolved & 10 & 1 & 10 & 14 & 25 & 32 & 36 & 38 \\
\hline Bicarbonate, dissolved & 10 & 1 & 10 & 17 & 30 & 40 & 44 & 46 \\
\hline Carbonate, dissolved & 7 & 1 & 0 & -- & -- & -- & -- & -- \\
\hline Chloride, dissolved & 10 & .20 & 10 & 27.4 & 28.2 & 29.2 & 33.3 & 35.8 \\
\hline Fluoride, dissolved & 10 & .20 & 0 & -- & -- & -- & -- & $<.20$ \\
\hline Sulfate, dissolved & 10 & .18 & 10 & 2.8 & 4.1 & 4.4 & 6.0 & 6.5 \\
\hline Silica, dissolved & 10 & .04 & 10 & 5.25 & 10.4 & 13.7 & 15.5 & 16.8 \\
\hline \multicolumn{9}{|l|}{ Nutrients (mg/L) } \\
\hline Ammonia + organic nitrogen, dissolved & 10 & .10 & 10 & .14 & .16 & .19 & .30 & .45 \\
\hline Ammonia + organic nitrogen, total & 10 & .10 & 10 & .31 & .34 & .38 & .42 & .64 \\
\hline Ammonia nitrogen, dissolved & 10 & .04 & 0 & -- & -- & -- & -- & -- \\
\hline Nitrite + nitrate nitrogen, dissolved & 10 & .06 & 9 & $<.06$ & .10 & .14 & .23 & .23 \\
\hline Nitrite nitrogen, dissolved & 10 & .010 & 0 & -- & -- & -- & -- & -- \\
\hline Nitrogen ${ }^{1}$, dissolved & 9 & -- & -- & .25 & .32 & .41 & .51 & .55 \\
\hline Nitrogen ${ }^{1}$, total & 9 & -- & -- & .46 & .50 & .55 & .63 & .73 \\
\hline Orthophosphate phosphorus, dissolved & 10 & .020 & 2 & $<.020$ & $<.020$ & $<.020$ & .020 & .020 \\
\hline Phosphorus, dissolved & 10 & .004 & 10 & .009 & .016 & .019 & .024 & .034 \\
\hline Phosphorus, total & 10 & .004 & 9 & $<.004$ & .061 & .075 & .084 & .091 \\
\hline Organic carbon, dissolved & 10 & .33 & 10 & 2.5 & 3.2 & 4.4 & 7.0 & 10.0 \\
\hline Organic carbon, total & 10 & .40 & 10 & 3.8 & 4.1 & 5.9 & 8.4 & 10.7 \\
\hline
\end{tabular}

Footnote at end of table. 
Appendix 6. Statistical summary of field measurements and physical properties, major cations and anions, nutrients, biological constituents, trace elements, and pesticides in samples collected from low flows at East Fork San Jacinto River, June 2000-September 2004-Continued.

\begin{tabular}{|c|c|c|c|c|c|c|c|c|}
\hline Constituent & $\begin{array}{c}\text { Num- } \\
\text { ber of } \\
\text { samples }\end{array}$ & $\begin{array}{l}\text { Mini- } \\
\text { mum } \\
\text { report- } \\
\text { ing } \\
\text { level }\end{array}$ & $\begin{array}{l}\text { Number of } \\
\text { detections } \\
\geq \text { reporting } \\
\quad \text { level }\end{array}$ & \multicolumn{5}{|c|}{ Concentration } \\
\hline \multicolumn{9}{|l|}{ Biological constituents } \\
\hline Plankton, biomass, ash weight & 9 & 0.1 & 9 & 280 & 329 & 344 & 500 & 1,300 \\
\hline E. coli bacteria (cols./100 mL) & 10 & 1 & 10 & E12 & 37 & 65 & 89 & 100 \\
\hline Fecal coliform bacteria (cols./100 mL) & 10 & 1 & 10 & E15 & 43 & 110 & 120 & 140 \\
\hline Fecal streptococcus bacteria (cols./100 mL) & 10 & 1 & 10 & E6 & 56 & 88 & 130 & 180 \\
\hline Chlorophyll- $a$ phytoplankton $(\mu \mathrm{g} / \mathrm{L})$ & 9 & .1 & 8 & $<.1$ & .4 & .8 & 1.3 & 1.7 \\
\hline Chlorophyll- $b$ phytoplankton $(\mu \mathrm{g} / \mathrm{L})$ & 9 & .1 & 2 & $<.1$ & $<.1$ & $<.1$ & $<.1$ & E.2 \\
\hline Arsenic, dissolved & 10 & 2.0 & 0 & -- & -- & -- & -- & -- \\
\hline Barium, dissolved & 10 & .2 & 10 & 54 & 60 & 64 & 70 & 75 \\
\hline Beryllium, dissolved & 8 & .06 & 0 & -- & -- & -- & -- & -- \\
\hline Cadmium, dissolved & 8 & .04 & 1 & $<.04$ & $<.04$ & $<.04$ & $<.04$ & .10 \\
\hline Chromium, dissolved & 10 & .8 & 1 & $<.8$ & $<.8$ & $<.8$ & $<.8$ & .8 \\
\hline Cobalt, dissolved & 8 & .014 & 8 & .316 & .330 & .341 & .376 & .437 \\
\hline Copper, dissolved & 10 & .4 & 10 & .8 & .9 & 1.0 & 1.7 & 2.3 \\
\hline Iron, dissolved & 10 & 10 & 10 & 23 & 33 & 60 & 122 & 163 \\
\hline Lead, dissolved & 8 & .08 & 3 & $<.08$ & $<.08$ & $<.08$ & .11 & .21 \\
\hline Manganese, dissolved & 10 & .2 & 10 & 40.5 & 43.8 & 54.1 & 65.0 & 67.4 \\
\hline Zinc, dissolved & 10 & 1.0 & 10 & 1.1 & 1.2 & 1.6 & 2.8 & 3.2 \\
\hline \multicolumn{9}{|l|}{ Pesticides ( $\mu \mathrm{g} / \mathrm{L})$} \\
\hline 2,6-Diethylaniline, dissolved & 10 & .006 & 0 & -- & -- & -- & -- & -- \\
\hline $\begin{array}{l}\text { 2-Chloro-4-isopropylamino-6-amino-s-triazine } \\
\text { (CIAT), dissolved }\end{array}$ & 10 & .006 & 0 & -- & -- & -- & -- & -- \\
\hline Acetochlor, dissolved & 10 & .006 & 0 & -- & -- & -- & -- & -- \\
\hline Alachlor, dissolved & 10 & .005 & 0 & -- & -- & -- & -- & -- \\
\hline alpha-HCH, dissolved & 10 & .005 & 0 & -- & -- & -- & -- & -- \\
\hline Atrazine, dissolved & 10 & .010 & 2 & $<.010$ & $<.010$ & $<.010$ & $<.010$ & .019 \\
\hline Azinphos-methyl, dissolved & 10 & .050 & 0 & -- & -- & -- & -- & -- \\
\hline Benfluralin, dissolved & 10 & .010 & 0 & -- & -- & -- & -- & -- \\
\hline Butylate, dissolved & 10 & .004 & 0 & -- & -- & -- & -- & -- \\
\hline Carbaryl, dissolved & 10 & .041 & 0 & -- & -- & -- & -- & -- \\
\hline Carbofuran, dissolved & 10 & .020 & 0 & -- & -- & -- & -- & -- \\
\hline Chlorpyrifos, dissolved & 10 & .005 & 0 & -- & -- & -- & -- & -- \\
\hline
\end{tabular}

Footnote at end of table. 
Appendix 6. Statistical summary of field measurements and physical properties, major cations and anions, nutrients, biological constituents, trace elements, and pesticides in samples collected from low flows at East Fork San Jacinto River, June 2000-September 2004-Continued.

\begin{tabular}{|c|c|c|c|c|c|c|c|c|}
\hline Constituent & $\begin{array}{c}\text { Num- } \\
\text { ber of } \\
\text { samples }\end{array}$ & $\begin{array}{l}\text { Mini- } \\
\text { mum } \\
\text { report- } \\
\text { ing } \\
\text { level }\end{array}$ & $\begin{array}{l}\text { Number of } \\
\text { detections } \\
\geq \text { reporting } \\
\quad \text { level }\end{array}$ & \multicolumn{5}{|c|}{ Concentration } \\
\hline \multicolumn{9}{|c|}{ Pesticides $(\mu \mathrm{g} / \mathrm{L})$-Continued } \\
\hline cis-Permethrin, dissolved & 10 & 0.006 & 0 & -- & -- & -- & -- & -- \\
\hline Dacthal (DCPA), dissolved & 10 & .003 & 0 & -- & -- & -- & -- & -- \\
\hline Desulfinyl fipronil, dissolved & 4 & .012 & 0 & -- & -- & -- & -- & -- \\
\hline Diazinon, dissolved & 10 & .005 & 2 & $<0.005$ & $<0.005$ & $<0.005$ & $<0.005$ & 0.019 \\
\hline Dieldrin, dissolved & 10 & .009 & 0 & -- & -- & -- & -- & -- \\
\hline Disulfoton, dissolved & 10 & .020 & 0 & -- & -- & -- & -- & -- \\
\hline Desulfinylfipronil amide, dissolved & 4 & .029 & 0 & -- & -- & -- & -- & -- \\
\hline Fipronil sulfide, dissolved & 4 & .013 & 0 & -- & -- & -- & -- & -- \\
\hline Fipronil sulfone, dissolved & 4 & .024 & 0 & -- & -- & -- & -- & -- \\
\hline Fipronil, dissolved & 4 & .016 & 0 & -- & -- & -- & -- & -- \\
\hline Fonofos, dissolved & 10 & .003 & 0 & -- & -- & -- & -- & -- \\
\hline Lindane, dissolved & 10 & .004 & 0 & -- & -- & -- & -- & -- \\
\hline Linuron, dissolved & 10 & .035 & 0 & -- & -- & -- & -- & -- \\
\hline Malathion, dissolved & 10 & .027 & 0 & -- & -- & -- & -- & -- \\
\hline Methyl parathion, dissolved & 10 & .015 & 0 & -- & -- & -- & -- & -- \\
\hline Metolachlor, dissolved & 10 & .013 & 0 & -- & -- & -- & -- & -- \\
\hline Pendimethalin, dissolved & 10 & .022 & 0 & -- & -- & -- & -- & -- \\
\hline Phorate, dissolved & 10 & .011 & 0 & -- & -- & -- & -- & -- \\
\hline Prometon, dissolved & 10 & .020 & 0 & -- & -- & -- & -- & -- \\
\hline Propyzamide, dissolved & 10 & .004 & 0 & -- & -- & -- & -- & -- \\
\hline Propachlor, dissolved & 10 & .025 & 0 & -- & -- & -- & -- & -- \\
\hline Propanil, dissolved & 10 & .011 & 0 & -- & -- & -- & -- & -- \\
\hline Propargite, dissolved & 10 & .020 & 0 & -- & -- & -- & -- & -- \\
\hline Simazine, dissolved & 10 & .011 & 0 & -- & -- & -- & -- & -- \\
\hline Tebuthiuron, dissolved & 10 & .020 & 1 & $<.020$ & $<.020$ & $<.020$ & $<.020$ & .030 \\
\hline Terbacil, dissolved & 10 & .034 & 0 & -- & -- & -- & -- & -- \\
\hline Terbufos, dissolved & 10 & .020 & 0 & -- & -- & -- & -- & -- \\
\hline Thiobencarb, dissolved & 10 & .010 & 0 & -- & -- & -- & -- & -- \\
\hline Tri-allate, dissolved & 10 & .002 & 0 & -- & -- & -- & -- & -- \\
\hline Trifluralin, dissolved & 10 & .009 & 0 & -- & -- & -- & -- & -- \\
\hline
\end{tabular}

\footnotetext{
${ }^{1}$ Nitrite + nitrate nitrogen plus ammonia + organic nitrogen.
} 
Appendix 7. Statistical summary of field measurements and physical properties, major cations and anions, nutrients, biological constituents, trace elements, and pesticides in samples collected from high flows at East Fork San Jacinto River, April 2002-November 2004.

[ $\geq$, equal to or greater than; $\mu \mathrm{S} / \mathrm{cm}$, microsiemens per centimeter at 25 degrees Celsius; ${ }^{\circ} \mathrm{C}$, degrees Celsius; $\mathrm{mg} / \mathrm{L}$, milligrams per liter; NTU, nephelometric turbidity units; UV, ultraviolet; $\mathrm{cm}$, centimeters; $\mathrm{CaCO}_{3}$, calcium carbonate; --, not applicable or not computed; <, less than; cols./100 mL, colonies per 100 milliliters, $\mu \mathrm{g} / \mathrm{L}$, micrograms per liter; E, estimated]

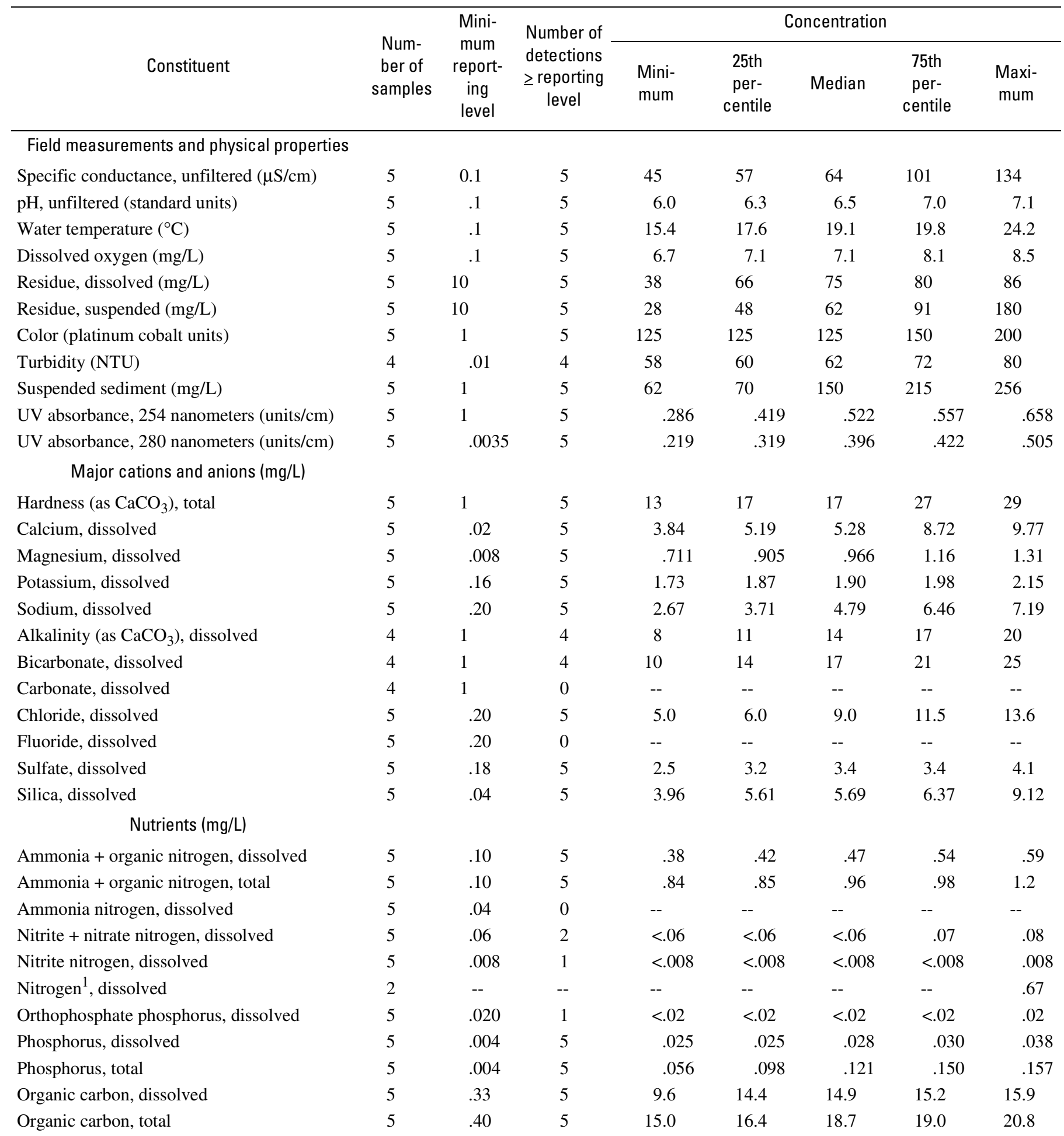


Appendix 7. Statistical summary of field measurements and physical properties, major cations and anions, nutrients, biological constituents, trace elements, and pesticides in samples collected from high flows at East Fork San Jacinto River, April 2002-November 2004-Continued.

\begin{tabular}{|c|c|c|c|c|c|c|c|c|}
\hline \multirow[b]{2}{*}{ Constituent } & \multirow[b]{2}{*}{$\begin{array}{c}\text { Num- } \\
\text { ber of } \\
\text { samples }\end{array}$} & \multirow{2}{*}{$\begin{array}{l}\text { Mini- } \\
\text { mum } \\
\text { report- } \\
\text { ing } \\
\text { level }\end{array}$} & \multirow[b]{2}{*}{$\begin{array}{c}\text { Number of } \\
\text { detections } \\
\geq \text { reporting } \\
\quad \text { level }\end{array}$} & \multicolumn{5}{|c|}{ Concentration } \\
\hline & & & & $\begin{array}{l}\text { Mini- } \\
\text { mum }\end{array}$ & $\begin{array}{l}\text { 25th } \\
\text { per- } \\
\text { centile }\end{array}$ & Median & $\begin{array}{c}\text { 75th } \\
\text { per- } \\
\text { centile }\end{array}$ & $\begin{array}{l}\text { Maxi- } \\
\text { mum }\end{array}$ \\
\hline \multicolumn{9}{|l|}{ Biological constituents } \\
\hline Plankton, biomass, ash weight & 5 & 0.1 & 5 & 723 & 930 & 1,010 & 1,470 & 1,510 \\
\hline Plankton, biomass, dry weight & 5 & .1 & 5 & 740 & 956 & 1,040 & 1,500 & 1,550 \\
\hline E. coli bacteria (cols./100 mL) & 4 & 1 & 4 & 2,100 & 2,500 & 3,900 & 3,500 & 5,800 \\
\hline Fecal coliform bacteria (cols./100 mL) & 4 & 1 & 4 & 2,300 & 2,600 & 3,200 & 4,700 & 5,800 \\
\hline Fecal streptococcus bacteria (cols./100 mL) & 4 & 1 & 4 & 3,100 & 3,400 & 4,200 & 5,400 & 6,000 \\
\hline Chlorophyll- $a$ phytoplankton $(\mu \mathrm{g} / \mathrm{L})$ & 4 & .2 & 3 & $<.2$ & $<.2$ & .8 & 1.5 & E1.8 \\
\hline Chlorophyll- $b$ phytoplankton $(\mu \mathrm{g} / \mathrm{L})$ & 4 & .1 & 1 & $<.1$ & $<.1$ & $<.1$ & $<.1$ & E.2 \\
\hline \multicolumn{9}{|l|}{ Trace elements $(\mu \mathrm{g} / \mathrm{L})$} \\
\hline Aluminum, dissolved & 5 & 1.6 & 5 & 16 & 39 & 44 & 58 & 303 \\
\hline Antimony, dissolved & 5 & .2 & 0 & -- & -- & -- & -- & -- \\
\hline Arsenic, dissolved & 5 & 2.0 & 0 & -- & -- & -- & -- & -- \\
\hline Barium, dissolved & 5 & .2 & 5 & 23 & 25 & 31 & 44 & 46 \\
\hline Beryllium, dissolved & 5 & .06 & 1 & $<.06$ & $<.06$ & $<.06$ & $<.06$ & .09 \\
\hline Cadmium, dissolved & 5 & .04 & 2 & $<.04$ & $<.04$ & $<.04$ & .04 & .04 \\
\hline Chromium, dissolved & 5 & .8 & 0 & -- & -- & -- & -- & -- \\
\hline Cobalt, dissolved & 5 & .014 & 5 & .067 & .105 & .106 & .162 & .175 \\
\hline Copper, dissolved & 5 & .4 & 5 & 2.2 & 2.3 & 2.5 & 2.8 & 3.0 \\
\hline Iron, dissolved & 5 & 10 & 5 & 122 & 154 & 173 & 204 & 335 \\
\hline Lead, dissolved & 5 & .08 & 5 & .12 & .13 & .17 & .29 & .43 \\
\hline Manganese, dissolved & 5 & 1.0 & 5 & .9 & 1.9 & 4.4 & 6.7 & 8.7 \\
\hline Mercury, dissolved & 5 & .2 & 0 & -- & -- & -- & -- & -- \\
\hline Molybdenum, dissolved & 5 & .4 & 0 & -- & -- & -- & -- & -- \\
\hline Nickel, dissolved & 5 & .06 & 5 & 1.41 & 1.43 & 1.50 & 1.50 & 1.57 \\
\hline Selenium, dissolved & 5 & 3.0 & 0 & -- & -- & -- & -- & -- \\
\hline Silver, dissolved & 5 & 1.0 & 0 & -- & -- & -- & -- & -- \\
\hline Uranium, dissolved & 5 & .04 & 5 & .08 & .12 & .12 & .13 & .14 \\
\hline Zinc, dissolved & 5 & 1.0 & 5 & 3.1 & 3.7 & 5.9 & 6.1 & 6.7 \\
\hline \multicolumn{9}{|l|}{ Pesticides $(\mu \mathrm{g} / \mathrm{L})$} \\
\hline 2,6-Diethylaniline, dissolved & 5 & .006 & 0 & -- & -- & -- & -- & -- \\
\hline $\begin{array}{l}\text { 2-Chloro-4-isopropylamino-6-amino-s-triazine } \\
\text { (CIAT), dissolved }\end{array}$ & 5 & .015 & 2 & $<.006$ & $<.006$ & $<.006$ & E.006 & E.006 \\
\hline Acetochlor, dissolved & 5 & .006 & 0 & -- & -- & -- & -- & -- \\
\hline Alachlor, dissolved & 5 & .005 & 0 & -- & -- & -- & -- & -- \\
\hline alpha-HCH, dissolved & 5 & .005 & 0 & -- & -- & -- & -- & -- \\
\hline Atrazine, dissolved & 5 & .007 & 4 & $<.007$ & .010 & .023 & .118 & .233 \\
\hline Azinphos-methyl, dissolved & 5 & .050 & 0 & -- & -- & -- & -- & -- \\
\hline Benfluralin, dissolved & 5 & .010 & 0 & -- & -- & -- & -- & -- \\
\hline Butylate, dissolved & 5 & .004 & 0 & -- & -- & -- & -- & -- \\
\hline Carbaryl, dissolved & 5 & .041 & 1 & $<.041$ & $<.041$ & $<.041$ & $<.041$ & E.121 \\
\hline Carbofuran, dissolved & 5 & .020 & 0 & -- & -- & -- & -- & -- \\
\hline
\end{tabular}

Footnote at end of table. 
Appendix 7. Statistical summary of field measurements and physical properties, major cations and anions, nutrients, biological constituents, trace elements, and pesticides in samples collected from high flows at East Fork San Jacinto River, April 2002-November 2004-Continued.

\begin{tabular}{|c|c|c|c|c|c|c|c|c|}
\hline \multirow[b]{2}{*}{ Constituent } & \multirow[b]{2}{*}{$\begin{array}{l}\text { Num- } \\
\text { ber of } \\
\text { samples }\end{array}$} & \multirow{2}{*}{$\begin{array}{l}\text { Mini- } \\
\text { mum } \\
\text { report- } \\
\text { ing } \\
\text { level }\end{array}$} & \multirow{2}{*}{$\begin{array}{l}\text { Number of } \\
\text { detections } \\
\geq \text { reporting } \\
\quad \text { level }\end{array}$} & \multicolumn{5}{|c|}{ Concentration } \\
\hline & & & & $\begin{array}{l}\text { Mini- } \\
\text { mum }\end{array}$ & $\begin{array}{c}25 \text { th } \\
\text { per- } \\
\text { centile }\end{array}$ & Median & $\begin{array}{c}\text { 75th } \\
\text { per- } \\
\text { centile }\end{array}$ & $\begin{array}{l}\text { Maxi- } \\
\text { mum }\end{array}$ \\
\hline \multicolumn{9}{|l|}{ Pesticides ( $\mu \mathrm{g} / \mathrm{L}$ )—Continued } \\
\hline Chlorpyrifos, dissolved & 5 & 0.005 & 0 & -- & -- & -- & -- & -- \\
\hline cis-Permethrin, dissolved & 5 & .006 & 0 & -- & -- & -- & -- & -- \\
\hline Cyanazine, dissolved & 5 & .018 & 0 & -- & -- & -- & -- & -- \\
\hline Dacthal (DCPA), dissolved & 5 & .003 & 0 & -- & -- & -- & -- & -- \\
\hline Desulfinyl fipronil, dissolved & 4 & .012 & 0 & -- & -- & -- & -- & -- \\
\hline Diazinon, dissolved & 5 & .005 & 3 & $<0.005$ & $<0.005$ & 0.017 & 0.018 & 0.051 \\
\hline Dieldrin, dissolved & 5 & .009 & 0 & -- & -- & -- & -- & -- \\
\hline Disulfoton, dissolved & 5 & .020 & 0 & -- & -- & -- & -- & -- \\
\hline EPTC, dissolved & 5 & .004 & 0 & -- & -- & -- & -- & -- \\
\hline Ethalfluralin, dissolved & 5 & .009 & 0 & -- & -- & -- & -- & -- \\
\hline Ethopropos, dissolved & 5 & .005 & 0 & -- & -- & -- & -- & -- \\
\hline Desulfinylfipronil amide, dissolved & 4 & .029 & 0 & -- & -- & -- & -- & -- \\
\hline Fipronil sulfide, dissolved & 4 & .013 & 0 & -- & -- & -- & -- & -- \\
\hline Fipronil sulfone, dissolved & 4 & .024 & 0 & -- & -- & -- & -- & -- \\
\hline Fipronil, dissolved & 4 & .016 & 0 & -- & -- & -- & -- & -- \\
\hline Fonofos, dissolved & 5 & .003 & 0 & -- & -- & -- & -- & -- \\
\hline Lindane, dissolved & 5 & .004 & 0 & -- & -- & -- & -- & -- \\
\hline Linuron, dissolved & 5 & .035 & 0 & -- & -- & -- & -- & -- \\
\hline Malathion, dissolved & 5 & .027 & 0 & -- & -- & -- & -- & -- \\
\hline Methyl parathion, dissolved & 5 & .015 & 0 & -- & -- & -- & -- & -- \\
\hline Metolachlor, dissolved & 5 & .013 & 0 & -- & -- & -- & -- & -- \\
\hline Metribuzin, dissolved & 5 & .006 & 0 & -- & -- & -- & -- & -- \\
\hline Molinate, dissolved & 5 & .003 & 0 & -- & -- & -- & -- & -- \\
\hline Napropamide, dissolved & 5 & .007 & 0 & -- & -- & -- & -- & -- \\
\hline$p, p^{\prime}$-DDE, dissolved & 5 & .003 & 0 & -- & -- & -- & -- & -- \\
\hline Parathion, dissolved & 5 & .010 & 0 & -- & -- & -- & -- & -- \\
\hline Pebulate, dissolved & 5 & .004 & 0 & -- & -- & -- & -- & -- \\
\hline Pendimethalin, dissolved & 5 & .022 & 0 & -- & -- & -- & -- & -- \\
\hline Phorate, dissolved & 5 & .011 & 0 & -- & -- & -- & -- & -- \\
\hline Prometon, dissolved & 5 & .010 & 0 & -- & -- & -- & -- & -- \\
\hline Propyzamide, dissolved & 5 & .004 & 0 & -- & -- & -- & -- & -- \\
\hline Propachlor, dissolved & 5 & .025 & 0 & -- & -- & -- & -- & -- \\
\hline Propanil, dissolved & 5 & .011 & 0 & -- & -- & -- & -- & -- \\
\hline Propargite, dissolved & 5 & .020 & 0 & -- & -- & -- & -- & -- \\
\hline Simazine, dissolved & 5 & .005 & 0 & -- & -- & -- & -- & -- \\
\hline Tebuthiuron, dissolved & 5 & .020 & 0 & -- & -- & -- & -- & -- \\
\hline Terbacil, dissolved & 5 & .034 & 0 & -- & -- & -- & -- & -- \\
\hline Terbufos, dissolved & 5 & .020 & 0 & -- & -- & -- & -- & -- \\
\hline Thiobencarb, dissolved & 5 & .010 & 0 & -- & -- & -- & -- & -- \\
\hline Tri-allate, dissolved & 5 & .006 & 0 & -- & -- & -- & -- & -- \\
\hline Trifluralin, dissolved & 5 & .009 & 0 & -- & -- & -- & -- & -- \\
\hline
\end{tabular}

${ }^{1}$ Nitrite + nitrate nitrogen plus ammonia + organic nitrogen. 
Prepared by the USGS Texas Water Science Center:

8027 Exchange Drive

Austin, TX 78754-4733

Information regarding water resources in Texas is available at http: //tx.usgs.gov/ 